University of Nebraska - Lincoln

DigitalCommons@University of Nebraska - Lincoln

Papers in the Earth and Atmospheric Sciences

Earth and Atmospheric Sciences, Department

1995

\title{
Cretaceous and Paleogene Manganese-Encrusted Hardgrounds from Central Pacific Guyots
}

\author{
David K. Watkins \\ University of Nebraska-Lincoln, dwatkins1@unl.edu \\ Isabella Premoli Silva \\ Università degli Studi di Milano \\ Elisabetta Erba \\ Università degli Studi di Milano, elisabetta.erba@unimi.it
}

Follow this and additional works at: https://digitalcommons.unl.edu/geosciencefacpub

Part of the Earth Sciences Commons

Watkins, David K.; Silva, Isabella Premoli; and Erba, Elisabetta, "Cretaceous and Paleogene ManganeseEncrusted Hardgrounds from Central Pacific Guyots" (1995). Papers in the Earth and Atmospheric Sciences. 221.

https://digitalcommons.unl.edu/geosciencefacpub/221

This Article is brought to you for free and open access by the Earth and Atmospheric Sciences, Department of at DigitalCommons@University of Nebraska - Lincoln. It has been accepted for inclusion in Papers in the Earth and Atmospheric Sciences by an authorized administrator of DigitalCommons@University of Nebraska - Lincoln. 


\title{
5. CRETACEOUS AND PALEOGENE MANGANESE-ENCRUSTED HARDGROUNDS FROM CENTRAL PACIFIC GUYOTS ${ }^{1}$
}

\author{
David K. Watkins, ${ }^{2}$ Isabella Premoli Silva, ${ }^{3}$ and Elisabetta Erba ${ }^{3}$
}

\begin{abstract}
Manganese-encrusted hardgrounds and associated sediments from four guyots in the western Pacific Ocean were investigated using lithostratigraphic and biostratigraphic examination of thin sections. Biostratigraphic data from manganese-encrusted hardgrounds constrain the age of platform drowning to early middle Eocene for Limalok Guyot, latest Maastrichtian to early Paleocene for Wodejebato Guyot, and middle late Albian for MIT Guyot. Microstratigraphic examination of the hardgrounds reveals a complex Cretaceous and Paleogene history of bioerosion, pelagic sediment accumulation, manganese encrustation, and phosphatization. Fourteen distinct episodes of pelagic sediment accumulation occurred, with five in the Cretaceous, three in the Paleocene, and seven in the Eocene. These episodes are thought to correspond with periods of decreased current velocities in the intermediate water masses that bathed the guyot summit plateaus. At least five episodes of manganese growth are documented: one in the Late Cretaceous to early Paleocene, and four in the Eocene. It is suggested that these correspond to periods of intensified intermediatewater current velocities. Five episodes of phosphatization are recognized. Two of these, Late Cretaceous to early Paleocene and latest Eocene to early Oligocene, probably correspond to events that have been recognized elsewhere in the Pacific. A third event (early middle Eocene) appears to correspond to the deposition of Horizon $\mathrm{A}^{\mathrm{c}}$ elsewhere in the world's oceans. It is suggested that increased upwelling during this event stimulated phosphatization on the guyot summits. The other two Eocene events are quite minor and may be localized to the Marshall Islands.
\end{abstract}

\section{INTRODUCTION}

Manganese-encrusted hardgrounds are common in the modern world's ocean system and in the geologic record. These hardgrounds are often the only preserved record of sedimentation during periods of negligible sediment accumulation. In the past, these units have often been overlooked or mentioned only as evidence of a disconformity. Others have derived paleoceanographic information from these units only by the use of expensive and time-consuming methods of chemical analysis. In this study, we have used lithostratigraphic and biostratigraphic analyses of thin sections to investigate the sequence and timing of paleoceanographic events recorded in these hardgrounds. These methods are relatively quick and simple, and are a natural complement to more traditional chemical analysis.

Ocean Drilling Program (ODP) Leg 144 recovered manganeseencrusted hardgrounds and associated sedimentary rocks from four guyots in the western Pacific Ocean. Three of the guyots (Limalok, Lo-En, and Wodejebato) are in the Marshall Island group of atolls and guyots. The fourth (Massachusetts Institute of Technology [MIT] Guyot) is an isolated feature near the Wake Group of guyots. These guyots share many characteristics with other guyots in the world's oceans. They consist of a volcanic edifice with an often flat-topped summit caused by subaerial or submarine erosion. Many have a shallow-water carbonate sequence atop the summit plateau. This formed when the guyot was near sea level, early in its subsidence history. Finally, many are capped by a sequence of pelagic sediments (herein referred to as the "pelagic cap") that accumulated as the guyot subsided into the pelagic realm. Limalok, Wodejebato, and MIT guyots possess all three elements; Lo-En lacks the carbonate platform complex in the vicinity where it was drilled by Leg 144. Manganese-encrusted hardgrounds and associated sediments underlie the pelagic cap on all four of the guyots examined in this paper.

\footnotetext{
${ }^{1}$ Haggerty, J.A., Premoli Silva, I., Rack, F., and McNutt, M.K. (Eds.), 1995. Proc. $O D P$, Sci. Results, 144: College Station, TX (Ocean Drilling Program).

${ }^{2}$ Department of Geology, University of Nebraska, Lincoln, NE 68588-0340, U.S.A.

${ }^{3}$ Dipartimento di Scienze della Terra, Università degli Studi di Milano, Via L. Mangiagalli 34, 1-20133 Milano, Italy.
}

The purpose of the present study is to examine the lithostratigraphic and biostratigraphic record of pelagic sedimentation and mineralization during the formation of these manganese crusts to gain insight into the paleoceanographic conditions that prevailed during their formation.

\section{MATERIALS AND METHODS}

The planktonic microfossil-bearing pelagic sediments in the hardgrounds examined for this study occur as sedimentary (reworked) clasts, as void fillings in shallow-water carbonate, as burrow and bore fillings, and as isolated specimens or within "pockets" of sediment trapped during manganese oxide deposition. Samples commonly contain several generations of pelagic material. The total volume of a particular generation of pelagic sediment may be significantly less than $1 \mathrm{~cm}^{3}$. One generation of pelagic sediment may be intimately associated with another generation of pelagic sediment or with preexisting shallow-water carbonate material. These relationships precluded the isolation of single generations of pelagic material by physical means. In addition, many specimens are partially or wholly replaced by either manganese oxides or calcium hydrophosphates. These specimens would be destroyed by attempts at physical separation. In most cases, therefore, these samples were studied in thin section. This method was highly advantageous as it allows observation of the original depositional relationships of the various assemblages. However, this methodology restricts the types of species abundance information that can be derived from the samples.

Although foraminifers can be easily examined in thin sections of standard thickness (approximately $30 \mu \mathrm{m}$ ), calcareous nannofossils are best observed in thin sections polished to a $10-15 \mu \mathrm{m}$ thickness. Grinding thin sections to a thickness of $10-15 \mu \mathrm{m}$ renders them nearly useless for other micropaleontologic or petrographic examinations. In many cases, petrologic and foraminiferal paleontologic examinations were performed on the thin sections (ground to standard thickness) before additional polishing for nannofossil examination. In other cases, duplicate slides were made from the same thin-section blank. Occasionally, it was necessary to produce two thin sections from adjacent pieces. Because of ODP conventions, these slides may not have the same interval depth in $\mathrm{cm}$. Such slides are denoted as 
"companion" slides. In most cases, it was possible to match the microfacies between adjacent companion slides. However, the irregular geometry of some microfacies resulted in significant differences between some companion slides. These are noted in the text.

Planktonic foraminifer identification using two-dimensional, thinsection views takes into account the type of cut, test size, growth-ratio patterns, chamber shape, type of margin, profile shape, size of umbilicus, type and thickness of the wall, and ornamentation. Most Cretaceous, Paleogene, and, to a minor extent, Neogene planktonic foraminifers can be identified to the species level using these elements.

The quantity of planktonic foraminifers varies from few to abundant, even in the small sample sizes examined in this study. Thus, abundance estimates are given whenever possible. Species diversity is more difficult to estimate because of the random orientation of the thin-section cuts and the diagenetic alteration (common replacement by calcium hydrophosphates or manganese oxide hydrates) of the foraminifers. Another bias in diversity estimation was winnowing, which in several samples strongly affected foraminifer deposition. Winnowing resulted generally in strong dilution of the large-sized, mainly age-diagnostic forms. Accumulation of fine-sized $(<125 \mu \mathrm{m})$ foraminifer tests was a common feature, especially in some zonal intervals. These accumulated faunas display a stratigraphically older character that is occasionally misleading. As a result, only presence/ absence data is reported for the planktonic foraminifer assemblages.

Because of their minute size, calcareous nannofossils occur in much greater abundance (generally) and yield more reliable abundance information. Estimations of the abundance of nannofossils as a sedimentary component were made from thin sections and (where possible) from smear slides of void-filling material. The following criteria were used: $\mathrm{A}=$ abundant (nannofossils comprise $>15 \%$ of the sediment), $\mathrm{C}=$ common (nannofossils comprise $5 \%-15 \%$ of the sediment, and $\mathrm{F}=$ few (nannofossils comprise $<5 \%$ of the sediment). It is important to note that the distribution of nannofossils in the thin sections can vary significantly in a given patch of pelagic sediment. Evidence of geopetal sediment fill is present in some voids or pockets; therefore, for example, nannofossils may be listed as "abundant" in the foraminifer nannofossil wackestone at the stratigraphic top of the pocket but only as "few" in the foraminiferal packstone at the base of the pocket. An indication of the distributional variation of the components is detailed in the discussion of specific samples. However, the reader is cautioned that the abundance designators given in the range charts are average values for the entire sediment clast or patch.

Semiquantitative methods of nannofossil abundance estimation normally used for smear slides and gravitationally settled samples are generally inappropriate for thin sections. This is particularly true of the thin sections of these hardgrounds. Semiquantitative methods depend explicitly on the uniform distribution of homogenized sediment on the slide and implicitly on the strong tendency for nannofossils to settle in orientations that facilitate identification (normally plan view). These conditions are not fulfilled by thin-section preparation of the sample. No homogenization of the sample is possible, as the specimens are frozen in cement. The distribution of nannofossil specimens is nonrandom and patchy, and their concentration in a given area can be a function of the thin-section thickness at that point. More importantly, many of the specimens in these thin sections are in orientations that preclude identification at the specific or even generic level. This problem is especially notable in the placoliths and the discoasters. Identification problems are compounded by the differing modes of preservation in these thin sections. In the case of preservation of the original skeletal material, the similarity in refractive indices between the low-magnesium calcite nannofossils and their enclosing calcareous or phosphatic cement renders the nannofossils nearly invisible in all types of illumination except cross-polarized light. Phosphatized nannofossils, which occur in some of these samples, are no longer birefringent and are visible only in ordinary or plane-polarized light. Phase contrast illumination is nearly useless for either calcitic or phosphate-replaced nannofossils in these thin sections.
Given these problems, only qualitative abundance estimates are used for these thin sections. Estimations of the relative abundances of individual species in a given sample were made by the following criteria: $\mathrm{A}=$ abundant $(>1$ specimen per field of view at $1250 \times), \mathrm{C}=$ common ( 1 specimen per $2-10$ fields of view at $1250 \times), F=$ few ( 1 specimen per $11-100$ fields of view at $1250 \times)$, and $R=$ rare $(<1$ specimen per 100 fields of view at $1250 \times$ ). This system is essentially that proposed by Hay (1970), except that the magnification has been increased from $1000 \times$ to $1250 \times$. This estimation system was used as stated for pelagic sediment clasts or patches that are large enough to contain more than 100 fields of view at $1250 \times$. Many of the sediment generations are smaller than this, however; in a few cases, the entire size of the preserved sediment in the thin section could be completely scanned in $<10$ fields of view at $1250 \times$. Literal use of the above criteria would demand that a single specimen would be reported as "common." This would be misleading. Thus, in these circumstances, single specimens are reported as "rare," species represented by $2-4$ specimens are reported as "few," species represented by 5-9 specimens are reported as "common," and species with more than one specimen per field of view are reported as "abundant."

Planktonic foraminifer preservation was quite variable, from relatively well-preserved forms to phosphatized ghosts or Mn-infilled tests that have lost the diagnostic characters of the walls. When phosphatization was strong, larger sized specimens maintained their shape and could still be identified, whereas small-sized forms were generally obscured. No clear patterns in preservation were detected; in general, however, older faunas in a sample tend to be less well preserved than the youngest. Planktonic foraminifers, in most instances, were visible only in cross-polarized light. These did not yield useful microphotographs; thus, they are not figured in this paper.

Preservation of the nannofossil material may vary radically within a single generation of pelagic sediment. This is especially true of those generations that were deposited in intimate association with manganese oxide hydrates. Such variations are evident within the space of a single millimeter. For example, it is not unusual to find that nannofossil preservation is "good" $1 \mathrm{~mm}$ away from a manganese oxide hydrate dendrite, "fair" within a few microns of the dendrite, and "poor" where the nannofossils are in physical contact with the dendrite. Indeed, it is possible to find "good" nannofossils within 20 $\mu \mathrm{m}$ of a dendrite and totally dissolved (occurring only as molds) within that dendrite. Similarly marked variations are evident in reworked sedimentary clasts, with "good" preservation at the center of the clast and "poor" preservation at the margins of the clast. In some cases, the preservation of nannofossils located within foraminiferal chambers is significantly different (commonly better) than specimens of the same species located just outside the foraminifer. Estimations of the nannofossil preservation on the range charts and within the text are based on the visual observation of specimens physically removed from marginal zones of interaction with other sedimentary phases unless otherwise noted. The reader should note, however, that preservational variation in these complex sediments is much greater than that typically observed in pelagic carbonates.

The multigenerational nature of many of the hardgrounds studied requires a system of nomenclature to delineate different generations of pelagic material clearly. In some cases, it is clear that one generation preceded another, either by microlithostratigraphic or biostratigraphic relationships. In other cases, such evidence is insufficient to elucidate the relationship within a given thin section. Although it is tempting to number the generations according to the results of the thin-section analyses (e.g., the oldest generation designated as "1," the next oldest as "2," and the youngest as " 3 "), such an interpretational numbering system holds the danger of implying age relationships where none can be proven. Thus, different generations of pelagic sediment occurring within a single thin section are numbered only by the order in which they were examined. The reader is thus warned that the numerical system carries no implication of stratigraphic relationship. 
Examination of the temporal relationships between generations of pelagic sedimentation, manganese oxide deposition, and phosphatization episodes requires examination of the stratigraphic relationships of these phases as well as their relationship with the underlying shallow-water carbonates. The thin-section descriptions given below are not meant to constitute an exhaustive or authoritative petrologic analysis, but merely to facilitate microstratigraphic deductions. Descriptions of the shallow-water carbonates given below are derived from the excellent descriptions done by the shipboard sedimentologists (Premoli Silva, Haggerty, Rack, et al., 1993), supplemented by our observations on the specific thin sections used in this study. The only petrologic data on the shallow-water carbonates for which we take full responsibility concern the presence of manganese oxide infillings of endolithic algal or fungal borings that penetrate the upper few millimeters of the shallow-water carbonates in some of the samples. Algal and fungal borings were differentiated following criteria from Bathurst (1966, 1975).

Biostratigraphic placement of the Cretaceous planktonic foraminifer assemblages follows the zonal scheme, foraminifer bioevents, and chronostratigraphy discussed in Erba et al. (this volume). Species concepts are according to Premoli Silva and Sliter (1994). Generic attribution of Paleocene to Eocene planktonic foraminifers is according to Olsson et al. (1992), whereas some species distributions in the same interval follow Toumarkine and Luterbacher (1985) and Premoli Silva and Boersma (1988).

Biostratigraphic zonation of the calcareous nannofossil assemblages observed in these diverse sediments follows the numerical scheme of Okada and Bukry (1980). This zonation was originally developed from sections in the equatorial Pacific by Bukry (1973, 1975). The equatorial oceanic bias of this zonation makes it preferable to that of Martini (1971), which was developed using assemblages from temperate continental margin settings. Additional or alternate biostratigraphic indicators have been used to improve the stratigraphic resolution. These additional biohorizons follow the compilation of Perch-Nielsen (1985) unless otherwise noted in the text. Zonation by Paleogene planktonic foraminifers follows the scheme of Berggren et al. (1985), as further explained by Berggren and Miller (1988). Correlation of the planktonic foraminifer and calcareous nannofossil biostratigraphies follow that of Berggren et al. (1985).

The calcareous nannofossil species identified in this work are illustrated in Plates 1-6. Range charts for Cretaceous, Paleocene, and Eocene nannofossil assemblages are given in Tables 1, 2, and 3, respectively. Because of the restrictions of observation discussed above, the vast majority are illustrated in polarized light, including taxa (such as the discoasters) that are seldom viewed in this light. Taxa included in this report are listed in the Appendix. Bibliographic references for these taxa are found in Loeblich and Tappan (1966, 1968, 1969, 1970a, 1970b, 1971, 1973), van Heck (1979a, 1979b, 1980a, 1980b, 1981a, 1981b, 1982a, 1982b, 1983), and Steinmetz (1984a, 1984b, 1985a, 1985b, 1986, 1987a, 1987b, 1988a, 1988b, 1989).

\section{RESULTS}

\section{Limalok Guyot}

Limalok Guyot (formerly Harrie Guyot) is located in the Ratak Chain of the southern Marshall Islands (see site map preceding title page). Limalok Guyot occupies the same volcanic pedestal as Mili Atoll. Although the shallow-water carbonate complex on Mili Atoll continues to thrive, shallow-water carbonate deposition on Limalok Guyot ceased during the middle Eocene (Premoli Silva, Haggerty, Rack, et al., 1993). Site 871 was located near the summit of Limalok Guyot, at $5^{\circ} 33.43^{\prime} \mathrm{N}, 172^{\circ} 20.66^{\prime} \mathrm{E}$ in $1255 \mathrm{~m}$ water depth. Manganese-encrusted hardgrounds, recovered from Holes $871 \mathrm{~A}$ and $871 \mathrm{C}$, occur stratigraphically between the top of the latest(?) Paleocene to middle Eocene shallow-water carbonates and the Miocene to Holocene pelagic cap chalks and oozes (see Nicora et al., this volume).
Small quantities of chalk filling cracks at the top of the shallowwater carbonate sequence (Sample 144-871C-2R-1, 0-2 cm) contain well-preserved calcareous microfossils. Calcareous nannofossils in this sample contain Dictyococcites bisectus, D. scrippsae, Sphenolithus predistentus, S. distentus, and Zygrhablithus bijugatus. This assemblage indicates Zone CP18 of mid-Oligocene age. Planktonic foraminifers in this sample include Globoquadrina tripartita, $G$. sellii, G. rohri, "Globigerina" ampliaperta, Turborotalia pseudoampliaperta, and $T$. increbescens associated with globorotaloids and catapsydracids. This assemblage indicates Zone P20 of early Oligocene age.

Sample 144-871 A-15H-CC, 10-13 cm, contains at least three generations of pelagic sediment. The major lithology consists of a foraminifer nannofossil wackestone to rudstone. Clasts in the rudstone include phosphatized grains of platform debris including larger foraminifers (e.g., Nummulites), smaller benthic foraminifers, and bivalve and echinoderm fragments as well as phosphatized or partially phosphatized shallow-water micrite grains. The rudstone contains a complex system of burrows and borings. The pelagic sediment filling the borings consists generally of foraminifer grainstone. The rudstone is bounded on two sides by manganese oxide crusts. One of these crusts is composed of alternating laminated and botryoidal manganese laminae, whereas the other side has a botryoidal crust that gives rise to a tightly packed system of manganese dendrites with intercalated pelagic sediment. A third generation of pelagic sediment, that fills a cavity at the top of the sample, consists of a foraminifer grainstone.

The matrix of the rudstone (Generation I) consists of a nannofossil limestone with rare, poorly preserved planktonic foraminifers. Calcareous nannofossils in this limestone are relatively well preserved although some signs of etching are obvious. The presence of common Reticulofenestra dictyota, Sphenolithus furcatolithoides, and Chiasmolithus solitus; and rare Nannotetrina cristata without Reticulofenestra umbilica indicate Zone CP13 of middle Eocene age. Pentaliths, including Braarudosphaera discula, Pemma basquensis, and $P$. stradnerii, are relatively common constituents of the assemblage.

The rudstone is penetrated by numerous burrows and borings that contain foraminifer grainstones (Generation II). Cross cutting relationships indicate that several episodes of boring and filling occurred. Biostratigraphic relationships suggest that this bioerosion occurred over a relatively long time. One boring contains planktonic foraminifers that include Turborotalia cocoaensis, T. cerroazulensis gr., large-sized Pseudohastigerina danvillensis, and "Subbotina" gortanii. This fauna seems to indicate the base of the upper Eocene, Zone P15. In another burrow, planktonic foraminifers including Turborotalia cerroazulensis, Globigerinatheka index, "G." senni, Acarinina topilensis, A. rohri, Globanomalina pseudoscitula, and other acarininds indicate Zone P14.

A cavity (boring?) at the top of the thin section contains a foraminifer grainstone (Generation III) with an homogeneous planktonic foraminifer fauna probably belonging to Zone P19 of early Oligocene age. A sparse calcareous nannofossil assemblage contains species that are consistent with the foraminifer age determination.

Sample 144-871C-2R-1, 1-6 cm, consists of shallow-water carbonate that is penetrated by two large, sediment-filled borings. The shallow-water carbonate is a benthic-foraminifer wackestone containing abundant miliolids and bivalve fragments. The wackestone has been phosphatized pervasively. Each of the two borings contains two distinct generations of pelagic sediment.

Generation I consists of a foraminifer nannofossil limestone that has been totally replaced by calcium phosphate. Clasts of phosphatized, manganese-encrusted grains of shallow-water carbonate are sparsely scattered through the phosphatized limestone. Replacement "ghosts" of planktonic foraminifers include a few specimens attributable to Acarinina rohri and other muricate forms. Few large lagenids including Lenticulina and some rotaliforms also occur as replacement ghosts. This fauna cannot be younger than Zone P14 of late middle 
Table 1. Cretaceous calcareous nannofossils from manganese-encrusted hardgrounds.

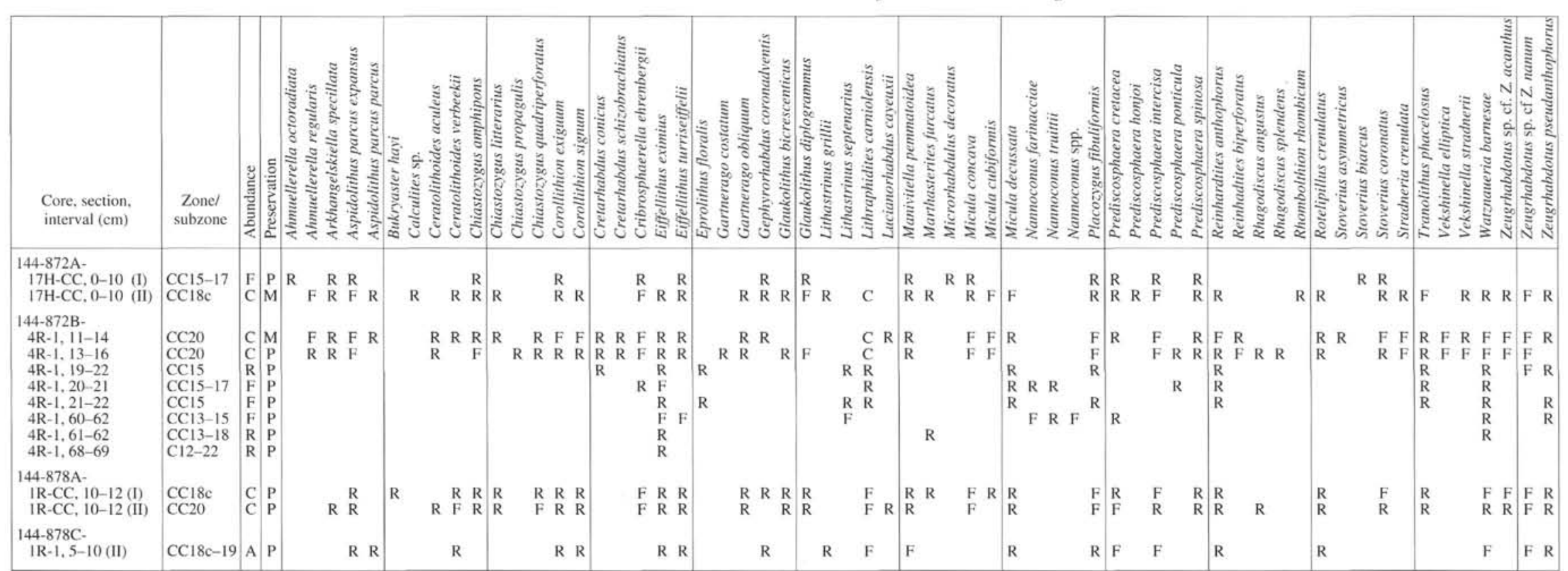


Table 2. Paleocene calcareous nannofossils from manganese-encrusted hardgrounds.

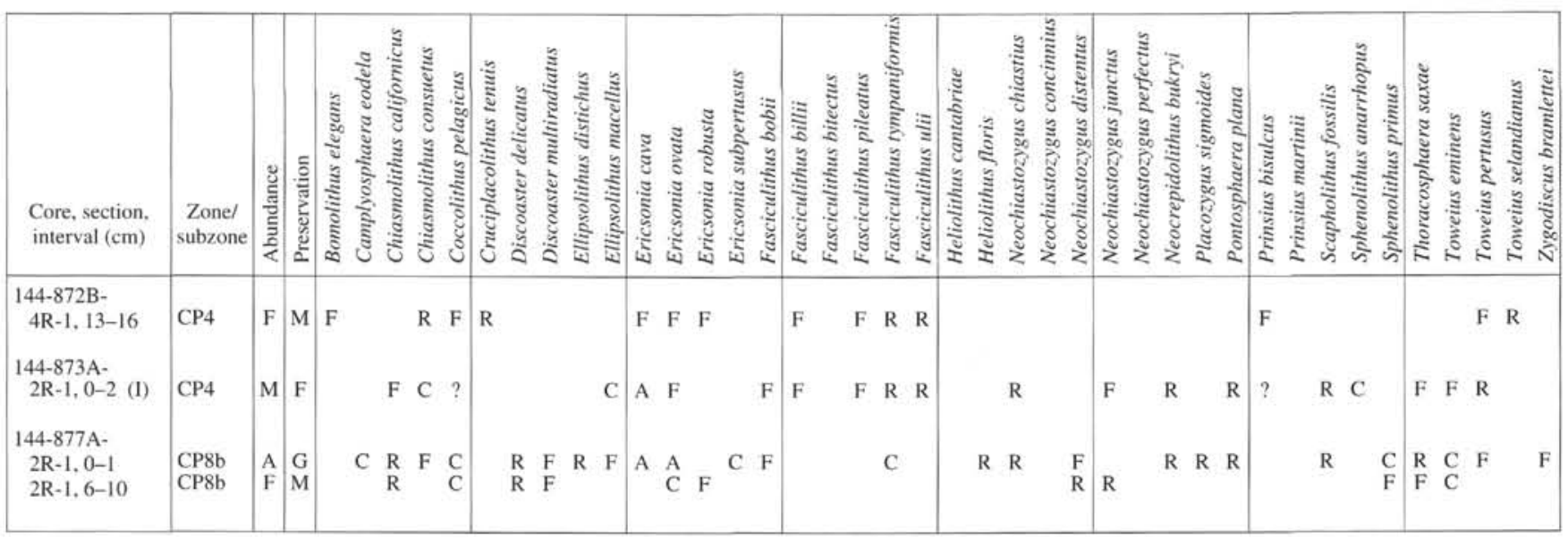

Eocene age. Phosphate-replaced nannofossils include Sphenolithus pseudoradians, S. predistentis, Reticulofenestra dictyota, Coccolithus eopelagicus, and Pseudotriquetrorhabdus inversus. This assemblage cannot be older than Subzone CP14b of late middle Eocene age. The correlation of the foraminifer and nannofossil data suggests a late middle Eocene age assignment for this material.

Generation II is separated from Generation I by a thin $(20-30 \mu \mathrm{m})$ manganese oxide crust. Generation II consists of a foraminifer grainstone with a well preserved and rich planktonic foraminifer assemblage. Species identified include Globoquadrina tripartita, G. sellii, G. rohri; Turborotalia pseudoampliapertura, T. increbescens; Catapsydrax sp.? Globorotaloides sp., tenuitellids, Pseudohastigerina micra, P. naguewichiensis, and Chiloguembelina sp. This fauna indicates Zone P19 of early Oligocene age. Sparse nannofossils in the foraminiferal interstices include Discoaster tanii, Cyclicargolithus abisectus, Dictyococcites bisectus, and Sphenolithus moriformis. This assemblage is consistent with the planktonic foraminifer age assignment.

\section{Lo-En Guyot}

Site 872 is located at $10^{\circ} 05.85^{\prime} \mathrm{N}, 162^{\circ} 51.96^{\prime} \mathrm{E}$, in a water depth of $1084 \mathrm{~m}$, on the central summit plateau of Lo-En Guyot, in the northern Marshall Islands. Lo-En Guyot shares the volcanic pedestal with the living Anewetak (formerly Eniwetok) Atoll. Unlike the other guyots drilled during Leg 144, Lo-En Guyot lacked a shallow-water carbonate platform complex on its summit plateau. The Neogene pelagic cap lies directly upon the volcanic edifice, separated only by a thin (>1 m) sequence of Upper Cretaceous and Paleogene sedimentary rocks. These sedimentary rocks, examined from Holes $872 \mathrm{~A}$ and $872 \mathrm{~B}$, include phosphatized pelagic limestones filling fractures in the underlying basalt, phosphate and manganese-encrusted pebble conglomerates, and chalk.

Section 144-872A-17H-CC contains fragments of a pebble conglomerate (Premoli Silva, Haggerty, Rack, et al., 1993, "Site 872" chapter, figs. 8-9). Clasts in the conglomerate include volcaniclastic sandstones, chalk, phosphatized pelagic limestone, phosphatized echinoderm fragments, and basalt. At least three generations of pelagic sediment have been identified in this thin section.

The volcaniclastic sandstone and basalt pebbles are cemented together with a matrix of phosphatized pelagic limestone and manganese oxide crusts. The phosphatized pelagic limestone contains phosphatereplaced common calcareous nannofossils and planktonic foraminifers. At least two generations of Cretaceous pelagic limestone are evident from the biostratigraphic analyses. Generation I contains common but poorly preserved planktonic foraminifers. Species identified include few Heterohelix globulosa, Heterohelix reussi (some transitional to Pseudotextularia sp.), Globigerinelloides bollii, and rare
Marginotruncana renzi, M. pseudolinneaiana, M. sigali, Globotruncanita elevata, G. stuartiformis, Contusotruncana fornicata, Ventilabrella glabrata; and a single specimen of Dicarinella concavata gr. The presence of $G$. elevata and $G$. stuartiformis along with rare specimens of the Dicarinella concavata gr. and V. glabrata indicates the upper part of the D. asymmetrica Zone and is late Santonian in age. Calcareous nannofossils in generation I include Aspidolithus parcus expansus, Micula concava, and Stoverius biarcus, suggesting a zonal assignment of CC15-CC17 (Santonian). Generation II consists of round to ovoid fields of phosphatized pelagic limestone that differ significantly in color and texture from the enclosing (Generation I) sediment. No grain truncation was observed at the contacts between Generations I and II. Generation II is interpreted to be infillings of burrows that were excavated while the older, Generation I sediment was still uncemented. Generation II contains calcareous nannofossil assemblages of approximately 35 species includes Aspidolithus parcus parcus, A. parcus expansus, Marthasterites furcatus, Lithastrinus grillii, and Ceratolithoides verbeekii. This association of taxa identifies Subzone $\mathrm{CC} 18 \mathrm{c}$ of early Campanian age.

Isolated pebbles of chalk also occur in Section 144-872A-17H-CC. These chalk pebbles consist of planktonic foraminifer grainstone to packstone. In addition to planktonic foraminifers, one Cretaceous shallow-water carbonate grain and rare phosphatic grains occur as clasts. The sediment texture and size distribution of the planktonic foraminifers suggests that this sediment was winnowed before deposition. Planktonic foraminifers are well preserved, homogeneous, and very abundant. Species identified include common Morozovella crassata and Acarinina topilensis; few Globigerinatheka index, G. subconglobata, "G." senni, Acarinina pseudotopilensis, A. rohri, A. bullbrooki, A. spinuloinflata, and Morozovella lehneri; rare Turborotalia possagnoensis, T. pomeroli, Pseudohastigerina micra, Guembelitrioides higginsi, Chiloguembelina sp., and Morozovella spinulosa, and very rare Igorina broedermanni, Acarinina pentacamerata, and Clavigerinella sp. The absence of Morozovella aragonensis and the presence of $T$. pomeroli suggest the lower part of Zone P12 of mid middle Eocene age. Abundant, moderately preserved calcareous nannofossils occur in the matrix of the packstone. The assemblage includes abundant Sphenolithus moriformis; common Pseudotriquetrorhabdus inversus, Dictyococcites bisectus, Sphenolithus spiniger, and Reticulofenestra dictyota; few Coccolithus eopelagicus, Dictyococcites scrippsae, and Reticulofenestra umbilica; and rare Discoaster bifax and Sphenolithus furcatolithoides. This assemblage is diagnostic for Subzone CP14a of middle Eocene age.

The various clasts in Section 144-872A-17H-CC are enclosed by a pale white planktonic foraminifer ooze. Calcareous nannofossil within this ooze include Dictyococcites bisectus, Zygrhablithus bijugatus, Cyclicargolithus pseudogammation, Sphenolithus distentus, 
Table 3. Eocene calcareous nannofossils from manganese-encrusted hardgrounds.

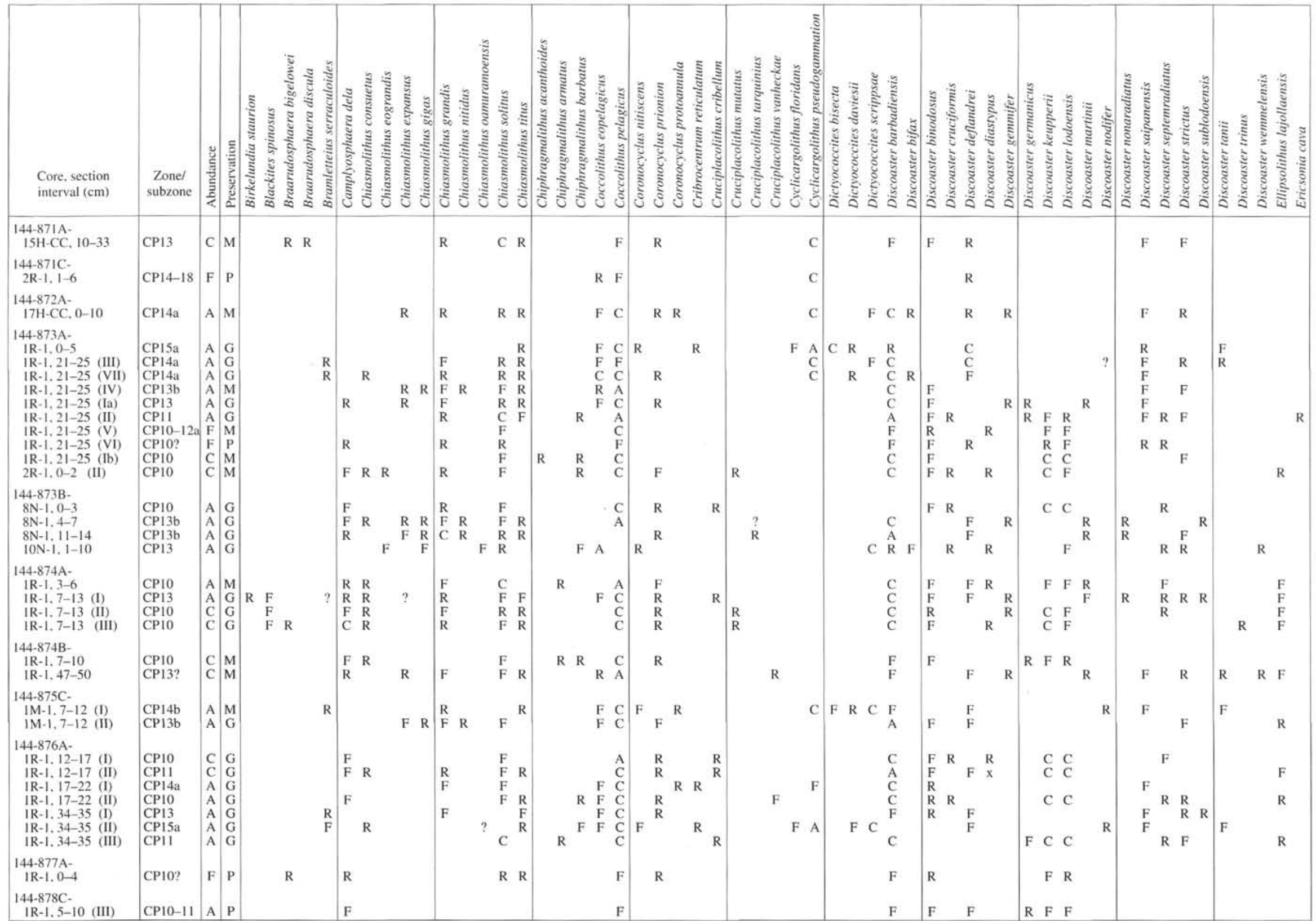


Table 3 (continued).

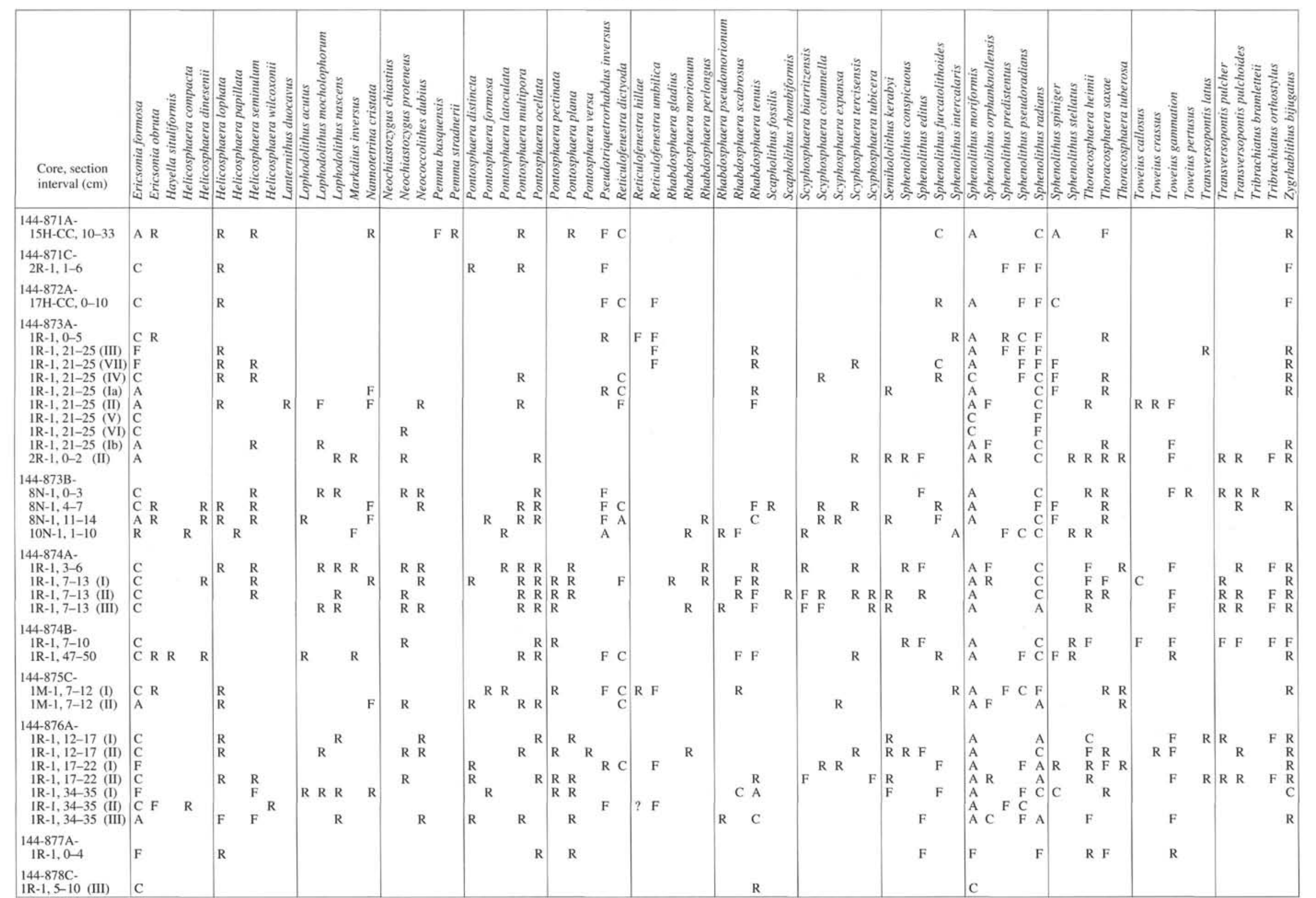


and $S$. ciperoensis. This assemblage indicates Subzone CP19a of late Oligocene age. This assemblage is essentially identical with that found in the overlying Section 144-872A-17H-3.

Sample 144-872B-4R-1, 11-14 cm, consists of a hyaloclastite(?) clast with phosphatized, conglomeratic, pelagic limestone adhering to the outside of the clast. Microfossils are confined to the conglomeratic pelagic limestone. Calcareous nannofossils and foraminifers have been completely replaced by calcium phosphate. Planktonic foraminifer assemblages are dominated by Heterohelix spp. Species identified include G. stuartiformis, Globotruncana arca, G. elevata, G. lapparenti, G. linneiana, G. bulloides, G. hilli, Globotruncana sp. cf. G. ventricosa, Globigerinelloides bollii, G. prairiehillensis, G. messinae, Contusotruncana fornicata, Archaeoglobigerina cretacea, Heterohelix globulosa, Heterohelix punctulata, and Pseudoguembelina costulata(?). This association of taxa indicates a mid-Campanian age (upper G. elevata Zone to $G$. ventricosa Zone). Benthic foraminifers include Lenticulina. Phosphatized calcareous nannofossils in the matrix include Aspidolithus parcus parcus, Gephyrorhabdus coronadventis, Ceratolithoides verbeekii, and Ceratolithoides aculeus but lack Quadrum sissinghii. This association identifies Zone CC20 of mid-Campanian age, in agreement with the planktonic foraminiferal evidence.

Sample 144-872B-4R-1, 13-16 cm, consists of a pebble conglomerate containing clasts of strongly phosphatized, fine-grained sediment and volcanic pebbles (Premoli Silva, Haggerty, Rack, et al., 1993, "Site 872 " chapter, fig. 10). One strongly phosphatized pebble contains specimens of the planktonic foraminifers Heterohelix sp., Hedbergella sp., and unidentifiable keeled forms. Rare calcareous nannofossils in this clast include Chiastozygus sp. cf. C. litterarius, Prediscosphaera columnata (small morphotype), and Zeugrhabdotus sp. This association of taxa suggests an Albian to earliest Cenomanian age for this clast. The matrix of the pebble conglomerate consists of highly phosphatized pelagic limestone containing few, poorly preserved planktonic foraminifers. Species identified (mainly a single specimen each) include G. stuartiformis; $M$. sigali, Globotruncana arca, G. lapparenti, G. linneiana, G. bulloides, G. hilli, G. rosetta(?), Globigerinelloides bollii, G. prairiehillensis, G. messinae, Archaeoglobigerina cretacea, Heterohelix globulosa, and Pseudoguembelina costulata(?). This assemblage belongs to the upper part of the G. elevata Zone or even to the Globotruncana ventricosa Zone (mid-Campanian). In addition to the planktonic foraminifers, the sand-sized fraction contains common fecal pellets, few fish remains, and few benthics including few Lenticulina and questionable Nuttallides. Calcareous nannofossils in the matrix include common, moderately preserved specimens with Aspidolithus parcus parcus, Gephyrorhabdus coronadventis, Ceratolithoides verbeekii, and Ceratolithoides aculeus. This association indicates Zone CC20 of mid-Campanian age.

A small volume of nannofossil limestone adheres to the edge of the pebble conglomerate in Sample 144-872B-4R-1, 13-16 cm (Premoli Silva, Haggerty, Rack, et al., 1993, "Site 872" chapter, fig. 10). This nannofossil limestone fills voids between pebbles of volcaniclastics and phosphatized (Cretaceous) pelagic limestone. In addition, it abuts directly up to the truncated margin of the manganese crust that forms part of the matrix between the pebbles. The calcareous nannofossil assemblage includes Fasciculithus janii, F. pileatus, F. ullii, F. tympaniformis (s.s.), and Bomolithus elegans. This assemblage indicates Zone CP4 of early late Paleocene age. Only fragments of foraminifers occur in this pelagic sediment.

Sample 144-872B-4R-1, 18-22 cm, consists of a conglomerate of basaltic pebbles in a matrix of phosphatized pelagic limestone (Premoli Silva, Haggerty, Rack, et al., 1993, "Site 872" chapter, fig. 11). Planktonic foraminifers are abundant but poorly preserved in the limestone matrix. Species identified include common Dicarinella concavata and Globigerinelloides bollii; few Marginotruncana renzi, M. sigali, M. pseudolinneiana, M. coronata, and Archaeoglobigerina cretacea; and rare Dicarinella primitiva, Marginotruncana schneegansi, Globigerinelloides prairiehillensis, G. messinae, G. caseyi, Globotruncana linneiana, G. hilli(?), Ventilabrella glabrata,
V. eggeri, Contusotruncana fornicata, and Hedbergella planispira. In addition, there is one possible Dicarinella asymmetrica (bad cut). This assemblage, in the absence of $G$. elevata, indicates the lower $D$. asymmetrica Zone of Santonianage. Other organisms in the sandsized fraction include few echinoderm fragments and benthic foraminifers with Lenticulina, Stensioina(?), and one multichambered agglutinant; very rare ostracods are also present.

Sample 144-872B-4R-1, 19-22 cm, is a companion slide to Sample $144-872 \mathrm{~B}-4 \mathrm{R}-1,18-22 \mathrm{~cm}$ (above). The planktonic foraminifer assemblage is similar to that of its companion slide with the addition of a possible Marginotruncana marginata. In addition, a specimen close to Globotruncanita elevata occurs in this thin section. In the absence of specimens of true G. elevata, this assemblage is assigned to the lower D. asymmetrica Zone of Santonian age. Benthic foraminifers are rather common and diversified including large Lenticulina, one possible Marssonella, Gavelinella, possible Globorotalites, and a large cross section of a lagenid(?). Few ostracods are present. An assemblage of rare, poorly preserved, phosphatized calcareous nannofossils include Eprolithus floralis, Lithastrinus septenarius, Micula decussata, and Reinhardtites anthophorus. This association of species indicates Zone CC15 of early Santonian age. This is consistent with the planktonic foraminifer age determination.

Fractures in the top of the basaltic edifice are filled with phosphatized pelagic limestone (Premoli Silva, Haggerty, Rack, et al., 1993, "Site 872" chapter, fig. 12). Planktonic foraminifer assemblages from these crack fillings are essentially similar to those in Sample 144872 B- 4 R-1, 18-22 cm, although they seem to exhibit a slightly older character. The assemblage includes abundant marginotruncanids and Heterohelix reussi; common Dicarinella concavata; and rare Dicarinella primitiva and whiteinellids. These assemblages indicate the Dicarinella concavata Zone of probable Coniacian age (Erba et al., this volume). Rare, phosphatized calcareous nannofossils from these crack fillings include Marthasterites furcatus and Eiffellithus eximius, whose ranges are consistent with the planktonic foraminifer age determination.

\section{Wodejebato Guyot}

Wodejebato Guyot (formerly Sylvania Guyot) is located approximately $44 \mathrm{~km}$ northwest of Pikinni Atoll (formerly Bikini Atoll) in the Ralik Chain of the northern Marshall Islands (see site map preceding title page). These two edifices occur on the same volcanic pedestal and are connected by a volcanic ridge at a water depth of approximately $1500 \mathrm{~m}$. Although Pikinni Atoll is characterized by a thick sequence of Cenozoic shallow-water carbonates that continue to accumulate today, Wodejebato Guyot experienced only a brief period of Late Cretaceous carbonate platform sedimentation before it drowned near the end of the Maastrichtian. Leg 144 drilled a set of five sites and nine holes from three areas of the guyot. The two holes at Site 873 sampled the stratigraphic section from the central part of the guyot, an area that corresponds with the central "lagoon" of the former carbonate platform. Sites 874 and 877 are located on the northeastern edge of the guyot on the bathymetric inner perimeter rim. Sites 875 and 876 are located on the northwestern margin of the guyot on the bathymetric outer perimeter rim. The composite stratigraphic sections recovered from holes in all three areas indicate that severely condensed sections of pelagic sediments were deposited during the early Paleogene.

\section{Site 873}

Sample 144-873A-1R-1, 0-5 cm, consists of a relatively large block of botryoidal hydrous manganese oxide that gives rise to a network of interfingering hydrous manganese oxide dendrites. The manganese dendrites are coated with a nearly uniform, 5-8 $\mu \mathrm{m}$ thick rim of isopachous fibrous cement (Fig. 1). The morphology of the cement suggests it was originally calcareous; however, the pseudo- 
isotropic extinction indicates that it is now phosphatic. Pelagic limestone occurs within pockets and recesses among the manganese dendrites. Neither planktonic foraminifers nor calcareous nannofossils lying in direct physical contact with the phosphatic rim show any indication of replacement by either phosphate or manganese oxides. Preservation of both microfossil groups is uniform and consistent within single pockets and between adjacent pockets. No nannofossils occur within the manganese dendrites or within the block of botryoidal manganese oxide. Abundant, well-preserved calcareous nannofossils occur tightly packed within the interstices of the manganese dendrites. The distribution of planktonic foraminifers and calcareous nannofossils is uniform throughout the pelagic limestone patches, with no definitive evidence of geopetal fabric. The nannofossil assemblages are dominated by abundant Sphenolithus moriformis and Cyclicargolithus pseudogammation with common Dictyococcites scrippsae, Sphenolithus pseudoradians, and Ericsonia formosa. Reticulofenestra umbilica, R. hillae, and Discoaster tanii are important secondary species in this assemblage. The presence of Cribrocentrum reticulatum and Sphenolithus intercalaris in the absence of Chiasmolithus grandis, C. solitus, and Isthmolithus recurvus indicate Subzone CP15a of early late Eocene age.

Sample 144-873A-1R-1, 0-7 cm, consists of a manganeseencrusted, limestone conglomerate containing fragments of shallowwater carbonate and phosphatized pelagic limestone cemented by pelagic limestone. At least three generations of pelagic limestone are evident. A phosphatized pebble of pelagic limestone contains a planktonic foraminifer fauna of late Paleocene age (Zone P4). Species identified include Morozovella pusilla, M. albeari, $M$. velascoensis, M. acuta; Acarinina nitida, Globanomalina sp. cf. G. chapmani, G. sp. cf. G. pseudomenardii, G. compressa, Chiloguembelina sp., and Parasubbotina pseudobulloides. A second generation of pelagic limestone includes a planktonic foraminiferal assemblage with rare "Globigerinatheka" senni, Acarinina rohri, Morozovella aragonensis, and Globigerinatheka sp.; and a single specimen of Morozovella crassata. This association is middle Eocene in age and probably belongs to Zone P11. A third generation of pelagic limestone includes an assemblage with few globigerinathekids, rare acarininids, and a single specimen of Turborotalia cerroazulensis s.str. This assemblage indicates Zone P14 of late middle Eocene age.

Sample 144-873A-1R-1, 16-20 cm, contains at least three generations of pelagic sediment. Generation I consists of phosphatized planktonic foraminifer faunas of Zone P4. Species identified include Morozovella conicotruncata, M. sp. cf. M. acuta, M. occlusa, Globanomalina pseudomenardii, and Acarinina sp. Generation II consists of pelagic limestone containing a planktonic foraminifer fauna rich in morozovellids. Species include Morozovella gracilis, $M$. aragonensis, Acarinina esnaensis, A. intermedia, and "Globigerinatheka" senni. This indicates the lower part of Zone P8 or the top of Zone P7. This assemblage contains the benthic foraminifer Nuttallides. Generation III consists of a small patch (boring/burrow fill?) with few planktonic foraminifers. The presence of Morozovella lehneri suggests assignment to middle Eocene Zone P12.

Sample $144-873$ A-1R-1, 21-25 cm, is a complex, multigenerational sample composed of a rudstone containing clasts that include shallow-water carbonate grains, pelagic limestone, older rudstones, and manganese nodules. The majority of the shallow-water carbonate clasts have been totally to partially replaced by phosphate, although a few of these grains are apparently unaltered (save for minor dissolution). The other clasts are described below.

A clast of shallow-water carbonate contains void fillings of brown, partially phosphatized, pelagic limestone (Generation VIII) with moderately preserved calcareous microfossils. This clast is rimmed by a discontinuous rind of manganese oxide. A few specimens of calcareous nannofossils within this pelagic void fill are identifiable (most are not) and include Fasciculithus tympaniformis, F. clinatus, Toweius eminens, Sphenolithus primus, and Discoaster multiradiatus. This sparse assemblage indicates Zone CP8 of late Paleocene

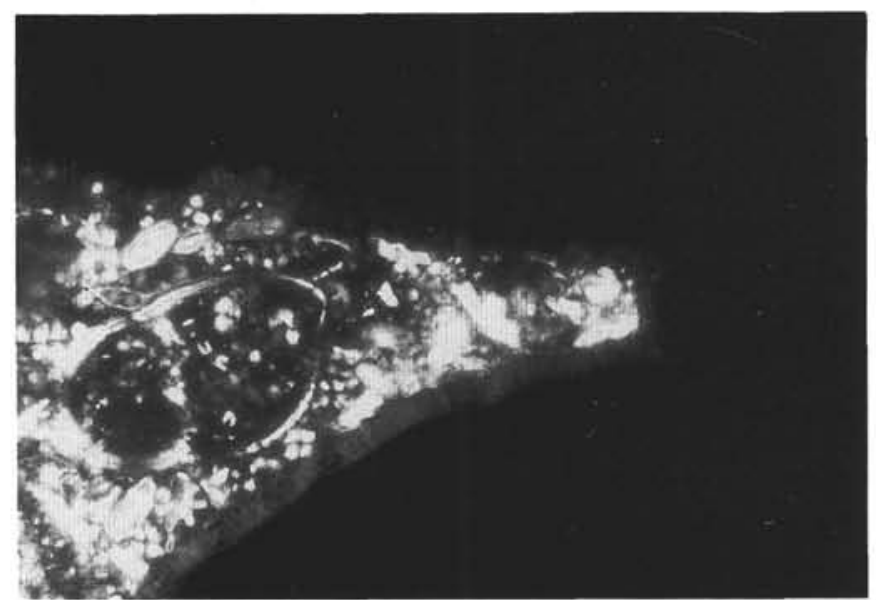

Figure 1. Rim of phosphatized isopachous fibrous cement lining voids in the network of manganese dendrites (black in photograph). Nannofossil foraminifer packstone fills void space but has not been replaced, indicating the phosphatization episode predated the early late Eocene age fill. Sample 144873 A-1R-1, 0-5 cm.

age. Planktonic foraminifers in a similar block from Sample 144873A-1R-1, 0-7 cm, include Morozovella velascoensis, $M$. pusilla, M. albeari, M. acuta, Acarinina nitida, Globanomalina compressa, G. sp. cf. G. chapmani, G. sp. cf. G. pseudomenardii, Parasubbotina pseudobulloides, and Chiloguembelina sp. This assemblage indicates Zone P4 of late Paleocene age, which is consistent with the nannofossil age from Generation VIII.

A clast of phosphatized micritic shallow-water carbonate (Fig. 2) contains irregular void fillings of nannofossil limestone (generation Ib). This clast is coated by a thin but continuous rind of manganese oxide. Common, moderately preserved calcareous nannofossils of generation Ib include abundant Sphenolithus moriformis; common Discoaster lodoensis, D. kuepperii, D. barbadiensis, and Coccolithus pelagicus; few Discoaster binodosus, D. strictus, and Toweius gammation; and rare Sphenolithus orphanknollensis, Chiphragmalithus acanthoides, and C. barbatus. This assemblage indicates assignment to Zone CP10 of early Eocene age. This clast is penetrated by a subcircular boring (Fig. 3) lined with concentric generations of phosphatic material (replaced calcite cement?). At the center of this lined boring is a fill of nannofossil foraminifer packstone (Generation Ia). Calcareous nannofossils in Generation Ia include abundant Ericsonia formosa and Sphenolithus moriformis, common Reticulofenestra dictyoda and Discoaster barbadiensis, few Nannotetrina cristata, and rare Discoaster martinii. This assemblage indicates CP13 of middle Eocene age. The apparent absence of Chiasmolithus grandis precludes subzonal assignment.

Generation II in Sample 144-873A-1R-1, 21-25 cm, consists of a large, rhombohedral block of mixed ooze and phosphate (Fig. 4). The interior of the clast exhibits a clear concentric structure delineated by variations in nannofossil and foraminiferal content. The original of this unusual fabric is enigmatic, although it may be the broken remains of a concentrically accreted burrow such as is found in Cylindrichnus. Regardless of its origin, it is clear from the irregular polygonal outline of the generation that it was a sedimentary clast before its final deposition. The clast is rimmed by a thick rind of manganese oxide, parts of which have given rise to a few manganese dendrites that penetrate the surrounding matrix. The calcareous nannofossil assemblages within this clast are apparently uniform across the concentric structure. These abundant, well-preserved nannofossils include abundant Sphenolithus moriformis, Discoaster barbadiensis, and Ericsonia formosa; common Sphenolithus radians, Chiasmolithus solitus; few Sphenolithus orphanknollensis, Discoaster kuepperii, and Reticulofenestra dictyoda; and rare Discoaster lodoensis, 


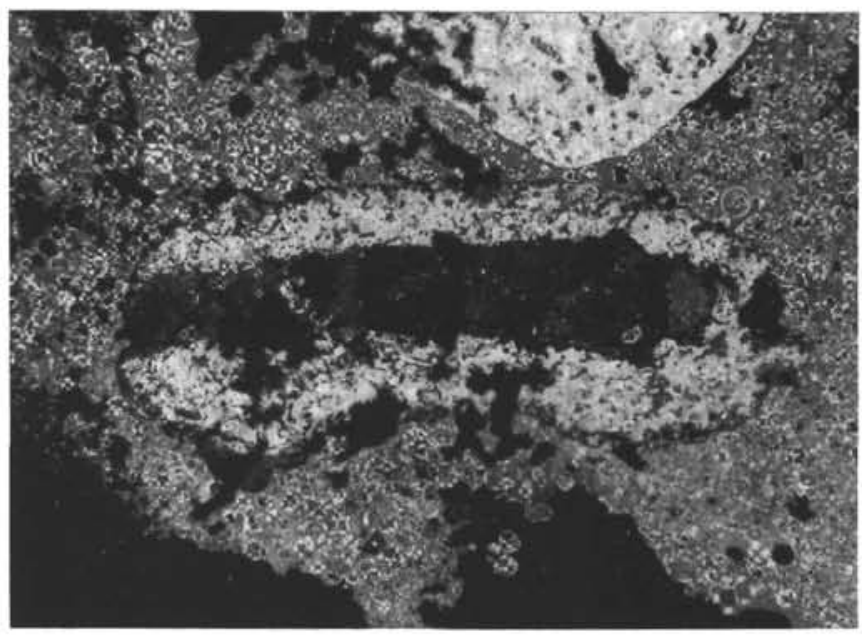

Figure 2. Manganese-rimmed clast of phosphatized micritic shallow-water carbonate containing irregular void fillings of lower Eocene (CP10) nannofossil foraminifer wackestone. The phosphate-lined bore featured in Figure 3 is on the right margin of the dark, central fill.

D. cruciformis, and Chiphragmalithus barbatus. This assemblage indicates Zone CP11 of early Eocene age.

Two manganese nodules occur within Sample 144-873A-1R-1, $21-25 \mathrm{~cm}$. The larger of the two is characterized by multiple growth centers that are in large part composed of concentric laminated phosphate with isolated patches of nannofossil limestone. Pelagic limestone (Generation IV) occurs between these growth centers (Fig. 5). Moderately preserved calcareous nannofossils of Generation IV include abundant Coccolithus pelagicus; common Ericsonia formosa, Reticulofenestra dictyoda, Sphenolithus moriformis, and Discoaster barbadiensis; few Sphenolithus spiniger, Discoaster saipanensis, and Chiasmolithus solitus; and rare Discoaster strictus, Sphenolithus furcatolithoides, and Chiasmolithus gigas. No specimens of Nannotetrina were observed in this small area; however, the presence of $C$. gigas in concert with the other taxa indicates Subzone CP13b of middle Eocene age. The smaller of the two manganese nodules in Sample 144-873A-1R-1, 21-25 cm, contains a small amount of intercalated pelagic limestone (Generation V). Few, moderately preserved nannofossils occur in Generation V including Discoaster lodoensis, D. kuepperii, and Chiasmolithus solitus. This sparse assemblage is not diagnostic for a specific zone, although the co-occurrence of these species indicates the interval from Zone CP10 through Subzone CP12a of early Eocene age.

The matrix of the rudstone in Sample 144-873A-1R-1, 21-25 cm. consists of foraminifer packstone to nannofossil foraminifer wackestone (Generation III). Sparsely scattered micritic grains, presumably derived from diminuted shallow-water carbonate, are present throughout Generation III. This pelagic limestone is penetrated in several places by manganese dendrites growing as extensions of the two manganese nodules and the thick rind of manganese that envelops the Generation II clast. Abundant, well-preserved calcareous nannofossils occur throughout Generation III. These assemblages include abundant Sphenolithus moriformis; common Discoaster deflandrei, D. barbadiensis, and Cyclicargolithus pseudogammation; few Dictyococcites scrippsae, Sphenolithus predistentus, Reticulofenestra umbilica; and rare Chiasmolithus solitus. This assemblage indicates Subzone $\mathrm{CP} 14 \mathrm{a}$ of late middle Eocene age. Generation III contains a very rich, well diversified, and homogeneous planktonic foraminifer fauna. Species identified include Turborotalia cerroazulensis, T. pomeroli, Morozovella crassata, $M$. lehneri, Globigerinatheka index, G. euganea gr., "Globigerinatheka" senni, and Subbotina sp. The presence of $T$. cerroazulensis in the absence of Acarinina bullbrooki gr. indicates Zone $\mathrm{P} 13$ or P14 of late middle Eocene in age. Benthic foraminifers

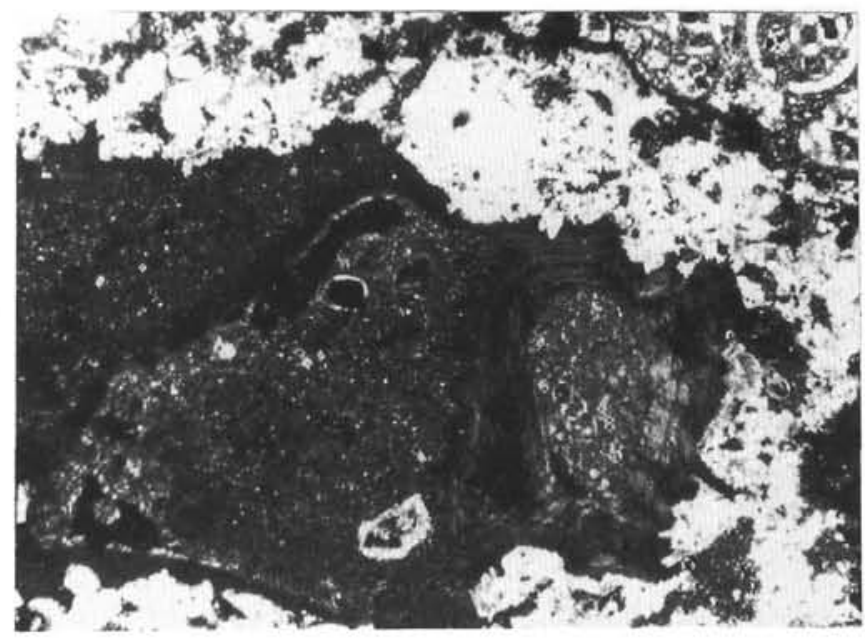

Figure 3. Close-up of clast in Figure 2 illustrating the nannofossil foraminifer wackestone fill within the bore. Note that the wall of the bore is lined by concentric rinds of phosphate.

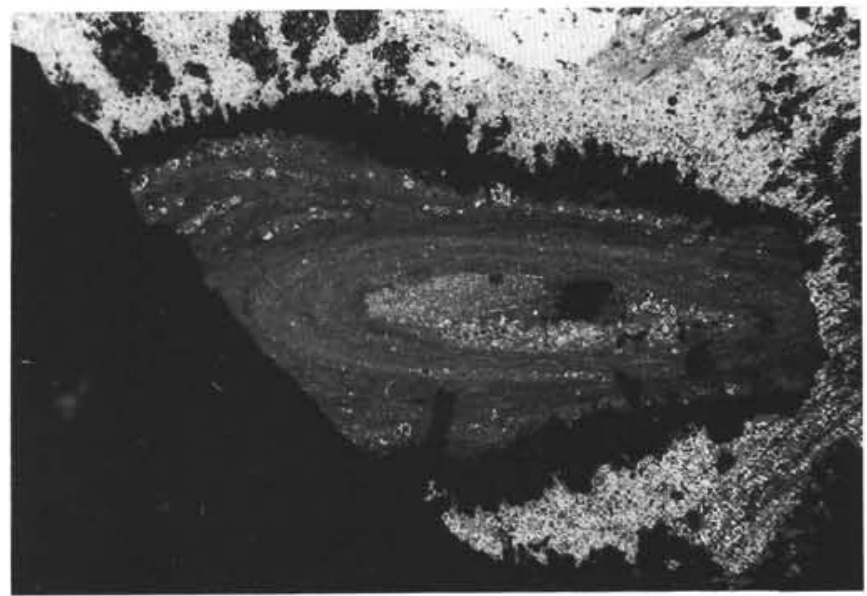

Figure 4. Unusual, concentrically layered sedimentary clast in Sample 144$873 \mathrm{~A}-1 \mathrm{R}-1,21-25 \mathrm{~cm}$. Note that the thick rim of manganese gives rise to manganese dendrites that penetrate the surrounding CP14a rudstone matrix.

are common with bolivinids, large lagenids (Lingulina?), Eponides or Nuttallides, and Gavelinella.

Sample 144-873A-2R-1, 0-2 cm, consists of a rudstone with a foraminiferal packstone to wackestone matrix overlain by a thin, botryoidal manganese oxide crust. This rudstone contains bioclastic grains (dominantly stromatoporoids) and reworked clasts of pelagic limestone. The pelagic limestone clasts are generally polygonal blocks that have been partially or completely altered by phosphatic replacement. Many bear a thin rim of isopachous radial or fibrous cement that has been altered to phosphate. In others, a rim of manganese that has partially penetrated the clast interior lies within a (discontinuous) rim of isopachous radial phosphatized cement. Core recovery in Cores $144-873 \mathrm{~A}-1 \mathrm{R}$ and $-2 \mathrm{R}$ was very poor, and it is likely that this sample is downhole caving from the stratigraphic interval penetrated by Core 144-873A-1R.

Several of the pelagic limestone clasts (Generation I) contain common, moderately preserved calcareous nannofossil assemblages. Calcareous nannofossils are less commonly preserved as identifiable species in smaller, partially phosphatized clasts. However, several of the larger pelagic limestone clasts contain moderately preserved assemblages that include common Sphenolithus primus, Ericsonia cava, 
E. ovalis, E. robusta, and Toweius eminens; few Fasciculithus bitectus, F. tympaniformis F. ulii, Neochiastozygus perfectus, and Toweius pertusus; and rare Sphenolithus anarrhopus, Bomolithus elegans, and Heliolithus cantabriae. This assemblage, in the absence of Heliolithus kleinpellii, indicates Zone CP4 of early late Paleocene age. The cooccurrence of $F$. bitectus, $H$. cantabriae, and $B$. elegans suggests the upper middle part of $\mathrm{CP} 4$. Pelagic limestone clasts from companion Sample 144-873A-2R-1, 0-5 cm, contain a P3b planktonic foraminifer fauna. Species identified include Globanomalina compressa, G. ehrenbergi, Morozovella pusilla, M. angulata, Parasubbotina pseudobulloides, and Muricoglobigerina mckannai. A few clasts contain a fauna of minute planktonic foraminifers that are densely packed (probably caused by winnowing) including common chiloguembelinids, Morozovella sp. cf. $M$. indolensis, and other unidentifiable species. This could be older material or the fine-grained fraction winnowed from other Subzone P3b material.

Small patches of pelagic limestone in companion Sample 144 $873 \mathrm{~A}-2 \mathrm{R}-1,0-5 \mathrm{~cm}$, contain a planktonic foraminifer assemblage including Morozovella velascoensis. This assemblage is most probably from Zone P4, although the small size of the pelagic limestone patches makes definitive assignment impossible.

The foraminiferal packstone to wackestone that forms the interparticle matrix for the rudstone contains common, moderately preserved, but very rich ( $>40$ species) calcareous nannofossil assemblages. These include abundant Sphenolithus moriformis and Ericsonia formosa; common Discoaster kuepperii, D. barbadiensis, and Sphenolithus radians; few Discoaster lodoensis, Tribrachiatus orthostylus, and Sphenolithus editus; and rare Sphenolithus conspicuus, Neococcolithus protenus, and Discoaster cruciformis. This association of taxa indicates Zone CP10 of early Eocene age. Similar assemblages occur within a few manganese coated burrows that penetrate the matrix. A Zone P8 planktonic foraminifer fauna was identified from the rudstone matrix in companion Sample 144-873A-2R-1, $0-5 \mathrm{~cm}$. These Eocene assemblages include large-sized, smaller benthic foraminifers.

Sample 144-873B-8N-1, 0-3 cm, consists of a bioclastic rudstone with a matrix of pelagic limestone. The sample is cut by a large (1.5-4 $\mathrm{mm}$ transverse diameter), irregular burrow filled with foraminifer nannofossil wackestone. The burrow is lined with a discontinuous rim of manganese oxide. Nannofossils are common and moderately preserved in the rudstone matrix as well as in the burrow fill. The nannofossil assemblages include abundant Sphenolithus moriformis; common Discoaster lodoensis, D. kuepperii, Coccolithus pelagicus, and Ericsonia formosa; and rare Tribrachiatus orthostylus and Discoaster cruciformis, indicating Zone CP10 of early Eocene age.

Sample 144-873B-8N-1, 4-7 cm, consists of a rudist skeletal grainstone with grains including fragments of rudists, stromatoporoids, larger foraminifers, echinoderms, and (rare) bryozoans. Many of the grains are micritized with some surviving only as micritic envelopes. Several phosphatized pelagic limestone clasts occur as grains (Generation I). Pelagic limestone (foraminifer packstone to wackestone) with minor amounts of micrite fills both interparticle spaces and subcylindrical penetrative structures interpreted as bore fillings (Generation II). Manganese encrustation is evident through the upper part of the thin section, with a network of finely laminated dendrites extending for more than $3 \mathrm{~cm}$ across the thin section. Skeletal grains and micritic envelopes are coated or partially rimmed by thin coatings of structureless manganese oxide. Manganese also coats or partially coats some of the planktonic foraminifers within the pelagic limestone. Irregular to spherical aggregates of manganese oxide are sparsely scattered throughout the pelagic limestone. The perimeters of many of these aggregates appear ragged, suggesting that they were corroded before their deposition as sedimentary particles within the pelagic limestone.

Generation I contains very phosphatized planktonic foraminifer assemblages of probable Zone P8 age including "Globigerinatheka" senni, Globanomalina planoconica, and Acarinina pseudotopilensis.

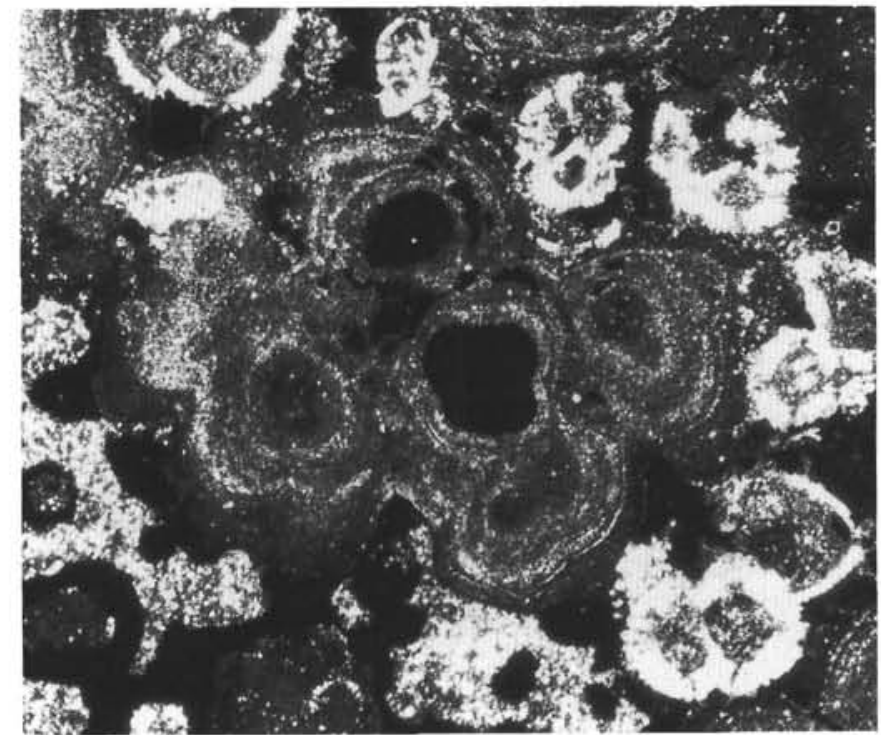

Figure 5. Middle Eocene (CP13b) pelagic limestone within the interstices of manganese dendrites that have concentrically laminated phosphate growth centers. Sample 144-873A-1R-1, 21-25 cm.

In some heavily phosphatized patches, the planktonic foraminifer faunas resemble older assemblages, but their age is uncertain because of the degree of alteration. These phosphatized pelagic limestone clasts are apparently barren of calcareous nannofossils. These may well have been destroyed by the phosphatization process.

A uniform assemblage of abundant, well-preserved calcareous nannofossils occurs throughout the pelagic limestone fills (Generation II). The nannofossil assemblage is quite diverse (richness $>35$ species) with Sphenolithus moriformis, Reticulofenestra dictyoda, Discoaster barbadiensis, and Coccolithus pelagicus being the most numerically abundant taxa. Biostratigraphically, the presence of $\mathrm{Nan}$ notetrina cristata and Chiasmolithus gigas indicate Subzone CP13b of middle Eocene age.

Companion Sample 144-873B-8N-1, 4-8 cm, contains a rich planktonic foraminifer assemblage from within the pelagic limestone intercalcated in a network of manganese dendrites. Species identified include few Globigerinatheka index and Morozovella lehneri, and rare Turborotalia pomeroli, Morozovella crassata, Acarinina topilensis, A. rohri, and Pseudohastigerina micra. Muricate forms are relatively less frequent than in Zone P12 material from other samples. This sample can be attributed to the transition between Zones P11 and P12.

Sample 144-873B-8N-1, 11-14 cm, is similar in lithologic character and biostratigraphic placement of the pelagic limestone (Subzone $\mathrm{CP} 13 \mathrm{~b}$ of middle Eocene age) to that in the overlying Sample 144-873B-8N-1, 4-7 cm.

Sample 144-873B-10N-1, 1-10 cm, consists of a bioclastic rudstone with a pelagic limestone matrix. Rudstone clasts are partially micritized and exhibit moldic porosity. Interparticle space and much of the moldic porosity is filled with nannofossil foraminifer packstone to wackestone. Nannofossils within the pelagic limestone matrix are abundant and well preserved. Assemblages include abundant Sphenolithus moriformis, Ericsonia formosa, Coccolithus pelagicus, and Reticulofenestra dictyoda; common Rhabdosphaera tenuis, Discoaster barbadiensis, and Sphenolithus spiniger; few Nannotetrina cristata and Discoaster martinii; and rare Discoaster bifax. The presence of $N$. cristata and the absence of Reticulofenestra umbilica indicates Zone CP13 of middle Eocene age. The total range of Discoaster bifax is used to delineate Subzone CP14a; however, Romein (1979) noted the occurrence of this species in Zone NP15 (approximately equivalent to CP13). Thus, the rare specimens of Discoaster bifax in this genera- 
tion are not considered to invalidate the assignment to CP13, but suggest that the sediment is from the upper part of CP13.

\section{Site 874}

Sample 144-874A-1R-1, 3-6 cm, consists of shallow-water carbonate overlying a botryoidal manganese crust. The shallow-water carbonate is a foraminifer-rudist grainstone that, in this thin section, is largely micritized. Several very irregular vugs within the grainstone contain pelagic limestone. The outlines of the vugs are well delineated by continuous rims of botryoidal to structureless manganese oxide. The shallow-water carbonate bordering these vugs, as well as the area near the grainstone-manganese crust contact, has moderate to extensive fungal boring highlighted by bore fillings of manganese oxide. The pelagic limestone varies from a foraminiferal packstone to a foraminifer-bearing nannofossil wackestone. The smaller vugs are filled with nannofossil limestone. In the largest of the vugs, the floor is filled with foraminifer packstone that abruptly grades upward into nannofossil limestone, suggesting geopetal fill. Manganese staining of the foraminifers in this vug is evident. The calcareous nannofossil assemblages are very rich (approximately 45 species) despite moderate preservation. These assemblages include abundant Sphenolithus moriformis and Coccolithus pelagicus; common Chiasmolithus solitus, Toweius gammation, and Ericsonia formosa; few Discoaster lodoensis, D. kuepperii, Sphenolithus editus, S. orphanknollensis, and Tribrachiatus orthostylus; and rare Chiphragmalithus armatus. This association indicates Zone CP10 of early Eocene age.

Sample 144-874A-1R-1, 7-13 cm, consists of shallow-water carbonate penetrated by cavities filled with pelagic carbonate and topped by a manganese crust. The shallow-water carbonate is a foraminiferrudist grainstone that, in this sample, has been totally micritized so that only "ghosts" of neritic skeletal grains are discernible. Manganese oxide occurs as a botryoidal crust with scattered, discontinuous dendrites penetrating down into the foraminifer-rudist grainstone. The upper $2-4 \mathrm{~mm}$ of the shallow-water carbonate is penetrated by a dense network of algal and fungal borings that have been filled with structureless manganese oxide. At least four generations of pelagic limestone occur as fillings of cavities penetrating into the shallowwater carbonate.

Generation I in Sample 144-874A-1R-1, 7-13 cm, is a nannofossil foraminifer packstone to wackestone that fills an irregular cavity (boring?) that penetrates downward into the shallow-water carbonate. The walls of this cavity are discontinuously coated with manganese oxide, which appears to have been corroded before the deposition of the pelagic limestone. The pelagic limestone is penetrated by rounded manganese oxide botryoids, which appear to have been burrows that were subsequently filled by the laminated to structureless manganese oxide. Abundant, well-preserved calcareous nannofossils from this material include abundant Sphenolithus moriformis; common Discoaster barbadiensis, Sphenolithus radians, and Toweius callosus; and rare Nannotetrina cristata. This assemblage is diagnostic for Zone CP13 of middle Eocene age. The apparent absence of Chiasmolithus gigas precludes subzonal assignment for this material. Planktonic foraminifers from this generation include Turborotalia pomeroli and Hantkenina sp. but lack large globigerinathekids, indicating Zone P12. Correlation of the nannofossil and foraminifer ages suggests that this pelagic limestone is in the top of Zone CP13 and the base of Zone P12.

Generation II in Sample 144-874A-1R-1, 7-13 cm, fills a relatively straight-sided boring into the shallow-water carbonate. The sediment is a nannofossil foraminifer packstone or wackestone with abundant, well-preserved calcareous microfossils. The boring is blocked by an ostracode valve that apparently prevented large specimens of planktonic foraminifers from settling into the base of the boring. Hence, the upper fill has a packstone fabric whereas the lower fill is a wackestone. Other than the mechanical size fractionation caused by this obstruction, the microfossil assemblages appear to be identical throughout the bore filling. Planktonic foraminifers in this pelagic limestone include Morozovella aragonensis, $M$. gracilis, $M$. crassata, Globigerinatheka senni, Acarinina pseudotopilensis, and Pseudohasterigina danvillensis, indicating Zone P8 of early Eocene age. Calcareous nannofossils from this material include Discoaster lodoensis, D. kuepperii, and Tribrachiatus orthostylus. This assemblage is diagnostic of Zone CP10 of early Eocene age. A similar assemblage was observed in an adjacent but physically unconnected boring in this thin section (Sample 144874 A-1R-1, 7-13 cm (III) in Table 3).

A poorly preserved, phosphatized, planktonic foraminifer fauna confined to an elongated clast (Generation III) seems to contain a P4 (or P3?) fauna of late Paleocene age. It is winnowed and rich in Chiloguembelina sp.

In addition, a few, small patches of pelagic limestone contain numerous large globigerinathekids, Orbulinoides beckmanni, and Turborotalia pomeroli among others. This indicates Zone P13 of middle Eocene age. Finally, one small patch of pelagic sediment contains a single specimen attributable to Globanomalina palmerae. Assuming that the identification is correct, this indicates the presence of Zone P9 (late early Eocene in age).

Sample 144-874B-1R-1, 7-10 cm, consists largely of manganese oxide in the form of a botryoidal crust that gives rise to a network of manganese dendrites. Numerous pockets of pelagic limestone occur within the manganese crust and (especially) dendrite network. Calcareous nannofossils are common in this entrapped pelagic limestone. Preservation varies from pocket to pocket but can be characterized generally as moderate. The assemblages are dominated by abundant Sphenolithus moriformis with common S. radians and Coccolithus pelagicus. The presence of few Tribrachiatus orthostylus, Toweius callosus, and Sphenolithus editus with rare Discoaster lodoensis indicates Zone CP10 of early Eocene age.

Sample 144-874B-1R-1, 47-50 cm, consists of pelagic limestone filling cavities and fractures in shallow-water carbonate. The contact between the pelagic and shallow-water carbonates is lined by isopachous fibrous calcite cement with minor phosphate replacement. At least two generations of pelagic limestone fill are evident in this sample.

Generation I in Sample 144-874B-1R-1, 47-50 cm, consists of a foraminiferal nannofossil packstone containing dominantly pelagic components (as opposed to Generation II) with only minor, silt-sized fragments of shallow-water limestone. Abundant and rich planktonic foraminiferal and calcareous nannofossil assemblages exhibit good preservation. Manganese occurs as sparsely scattered, structureless masses of $20-100 \mu \mathrm{m}$ diameter. Planktonic foraminiferal assemblages include Morozovella aragonensis, M. querta, Acarinina pentacamerata, A. primitiva, A. pseudotopilensis, and Globigerinatheka senni, indicating Zone P8 of early Eocene age. The calcareous nannofossil is dominated by Sphenolithus moriformis and $S$. radians with common Rhabdosphaera tenuis. It includes Discoaster lodoensis, Chiasmolithus eograndis, C. grandis, and Sphenolithus orphanknollensis without Tribrachiatus orthostylus, indicating Zone CP11 of early Eocene age.

Pelagic limestone Generation II in Sample 144-874B-1R-1, 47$50 \mathrm{~cm}$, consists of a foraminiferal packstone to wackestone containing common grains of corroded shallow-water limestone (dominantly broken cement), common diminuted planktonic foraminiferal debris, few angular sand- to silt-sized grains of phosphatic material, and rare fragments of echinoderms. Few irregular, corroded, silt-sized grains of manganese oxide occur as sedimentary particles within the pelagic limestone. Manganese dendrites occur rarely throughout the pelagic limestone. Manganese staining of planktonic foraminifers is frequent, with rare aggregates of manganese oxide occurring as planktonic foraminiferal chamber fillings. Calcareous nannofossils are common components of the pelagic limestone matrix. Nannofossil preservation is quite variable, with significant etching associated with manganese dendrites and manganese replacement centers. A moderately preserved calcareous nannofossil assemblage contains abundant $\mathrm{Coc}$ colithus pelagicus and Sphenolithus moriformis and common Reticu- 
lofenestra dictyoda, Ericsonia formosa, and Sphenolithus radians. The presence of Sphenolithus furcatolithoides, S. spiniger, and (rare) Discoaster martinii, in combination with the other taxa, suggests a zonal assignment of CP13 of middle Eocene age. It should be noted, however, that the index fossil for this zone (Nannotetrina cristata) was not observed.

\section{Site 875}

Sample 144-875C-1M-1, 0-2 cm, consists of very small, irregular patches of pelagic limestone (burrow or cavity fillings?) in a matrix of shallow-water carbonate. This thin section may be cut parallel to the manganese crust. At least three, and possibly four, generations of pelagic fill are evident. The youngest contains a planktonic foraminifer fauna of middle Eocene Zone P12. Several patches contain planktonic foraminifer assemblages with Morozovella aragonensis, Pseudohastigerina danvillensis, and "Globigerinatheka" senni, indicating Zone P8 of early Eocene age. A third, heavily phosphatized generation of pelagic limestone includes a probable Zone P4 (late Paleocene age) planktonic foraminifer fauna. Finally, one patch contains a planktonic foraminifer assemblage with only minute forms. This assemblage is possibly older than Zone P4, suggesting an early Paleocene age.

Sample 144-875C-1M-1, 4-6 cm, contains a single, very rich assemblage of planktonic foraminifers with common large globigerinathekids and "Globigerinatheka" senni. Species identified include Turborotalia cerroazulensis (s. s.), T. pomeroli, Morozovella lehneri, M. crassata, M. spinulosa, Acarinina rohri, A. topilensis, Globigerinatheka rubriformis, G. subconglobata, G. index, G. tropicalis, Chiloguembelina sp., tenuitellids, Pseudohastigerina naguewichiensis, and Globanomalina pseudoscitula. Specimens attributable either to Globigerinatheka euganea or Orbulinoides beckmanni are also present.The occurrence of $T$. cerroazulensis and $P$. naguewichiensis would indicate Zone P14, but $O$. beckmanni, if correct, indicates Zone P13. This fauna is very similar to that recorded in Hole 874A.

Sample 144-875C-1M-1, 7-12 cm, consists of a bioclastic rudstone overlain by a dense, structureless manganese crust giving rise to networks of manganese dendrites containing intercalated pelagic limestone. At least two generations of pelagic limestone are evident in this thin section. Both generations contain common benthic foraminifers including large lagenids, Eponides, Gavelinella, and buliminids.

Generation I in Sample 144-875C-1M-1, 7-12 cm, consists of nannofossil foraminifer packstone to wackestone that occurs intercalated within a sparse network of manganese dendrites above the manganese crust. This pelagic limestone contains a very rich planktonic foraminifer assemblage dominated by large specimens including common large globigerinathekids. The small planktonic foraminifers were presumably removed by winnowing. Species identified include Turborotalia cerroazulensis s.s., T. pomeroli, Morozovella lehneri, Acarinina rohri, A. topilensis, Globigerinatheka subconglobata, G. index, G. euganea and Orbulinoides beckmanni, Chiloguembelina sp., tenuitellids, Pseudohastigerina micra, Globanomalina pseudoscitula. As in Sample 144-875C-1M-1, 4-6 cm, this assemblage should be attributed to Zone P13, but may be Zone P14. Calcareous nannofossils in this generation include abundant Sphenolithus moriformis; common S. pseudoradians, Reticulofenestra dictyoda, Dictyococcites scrippsae, Cyclicargolithus pseudogammation. and Ericsonia formosa; few Reticulofenestra umbilica; and rare Chiasmolithus grandis and Sphenolithus intercalaris. This association of taxa, in the absence of Chiasmolithus solitus, indicates Subzone $\mathrm{CP} 14 \mathrm{~b}$ of late middle Eocene age. This zonal assignment suggests that the planktonic foraminifers are more likely from Zone P14.

Generation II in Sample 144-875C-1M-1, 7-12 cm, is a nannofossil foraminifer packstone that partially or wholly fills the interparticle space in the bioclastic rudstone. The contact of the pelagic limestone matrix and the shallow-water clasts is defined by an isopachous fibrous cement that is discontinuously stained with manganese oxide.
Abundant, well-preserved calcareous nannofossils in this packstone include abundant Sphenolithus moriformis, S. radians, Ericsonia formosa, and Discoaster barbadiensis, with common Reticulofenestra dictyoda, few Nannotetrina cristata, and rare Chiasmolithus gigas. This assemblage is characteristic of Subzone CP13b of middle Eocene age. A rich fauna of planktonic foraminifers contains forms typical of upper Zone P11. Species include Morozovella lehneri, $M$. aragonensis, $M$. crassata, Acarinina pseudotopilensis, A. topilensis, A. spinuloinflata, Turborotalia boweri, T. possagnoensis, Chiloguembelina sp., Globigerinatheka index, Pseudohastigerina micra, and Globanomalina pseudoscitula. Many small forms have apparently been removed by winnowing.

\section{Site 876}

Sample 144-876A-1R-1, 4-8 cm, consists of a limestone breccia with cavity fillings of pelagic limestone and manganese crusts. The limestone breccia is dominated by angular clasts of shallow-water carbonate cemented and interpenetrated by manganese crust and dendrites. Rare Cretaceous planktonic foraminifers are associated with the shallow-water biogenic grains. Two of the irregular cavity fillings contain very tiny planktonic foraminifers. The small size of these forms suggests a possible early Paleocene age (Zone P $\alpha$ ?), although this may be misleading. It is possible that this tiny assemblage is the product of winnowing. A large, manganese-lined, cavity contains a rich assemblage of planktonic foraminifers of Zone P8 (early Eocene). Occasionally, less common planktonics apparently of the same age (Zone P8) are associated with abundant to very abundant Thoracosphaera in smaller cavity fillings.

Sample 144-876A-1R-1, 12-17 cm, records a complex sedimentary history in which at least three generations of sediment are present. These three generations are clearly demarcated on the thin section by borders of manganese crusts. Generation I consists of a rudstone containing angular clasts of shallow-water carbonate (dominantly stromatoporoid fragments) and micrite in a grain-supported fabric with high porosity. Rare Cretaceous planktonic foraminifers occur within the shallow-water carbonate material. The shallow-water carbonate grains are rimmed by manganese oxides. The interparticle pore space is partially filled with a matrix of foraminifer limestone. Many of the foraminifers are partially or wholly coated with manganese oxide. Several in the thin section are partially replaced by manganese oxide. The foraminifer limestone varies from a grainstone/ packstone to a wackestone. Foraminifer packing varies abruptly over distances of less than $5 \mathrm{~mm}$. Calcareous nannofossils vary similarly in abundance and packing. Calcareous nannofossil assemblages from this generation of sediment vary significantly in abundance throughout the thin section, but can be described generally as common. Preservation of these assemblages is good throughout. The assemblages are moderately rich (approximately 30 species) and dominated by abundant Sphenolithus moriformis, S. radians, and Coccolithus pelagicus with common Discoaster kuepperii, D. lodoensis, and D. barbadiensis. Thoracosphaera heimii and $T$. saxea are locally abundant in areas of tightly packed foraminifers, suggesting some degree of sediment winnowing occurred during the deposition of this generation. The occurrence of D. kuepperii, D. lodoensis, D. martinii, and Tribrachiatus orthostylus indicates Zone CP10 of early Eocene age. Companion Sample 144-876A-1R-1, 8-17 cm contains rudstone matrix with a Zone P8 (early Eocene) planktonic foraminifer fauna including Morozovella aragonensis, M. sp. cf. M. gracilis, Pseudohastigerina danvillensis, "Globigerinatheka" senni, Acarinina bullbrooki gr., Globanomalina pseudoscitula. This fauna is associated with abundant to very abundant Thoracosphaera.

Generation II in Sample 144-876A-1R-1, 12-17 cm, consists of a bioclastic rudstone similar in lithologic character to Generation I, except that some clasts of manganese-coated pelagic limestone occur in Generation II. Generations I and II are separated by a $1.5-2 \mathrm{~mm}$ (largely) structureless manganese oxide crust. Pelagic limestone fill- 
ing or partially filling the interparticle void space exhibits similar variation in foraminiferal packing in Generation II. The calcareous nannofossil assemblage in Generation II is somewhat richer (approximately 40 species) but shows similar dominance by abundant $S p h e-$ nolithus moriformis and Discoaster barbadiensis and common Ericsonia formosa, Sphenolithus radians, Discoaster kuepperii, and D. lodoensis. The presence of $D$. lodoensis, D. kuepperii, and Toweius crassus in the absence of Tribrachiatus orthostylus indicates Zone CP11 of early Eocene age. Several manganese-coated clasts of pelagic limestone within Generation II contain nannofossil assemblages that include $D$. lodoensis and $T$. orthostylus (CP10) as well as an array of primary, secondary, and tertiary species that is essentially identical to the pelagic limestone in Generation I. In addition, a single manganese coated clast contains two specimens of Watznaueria barnesae. Although this species is biostratigraphically indicative only of sediments ranging from Middle Jurassic through Cretaceous, the shallow-water carbonate grains within this clast imply that it was locally derived from the Maastrichtian platform material.

Generation III in Sample 144-876A-1R-1, 12-17 cm, consists largely of structureless manganese oxide with abundant intercalated pockets of nannofossil limestone scattered throughout within the manganese crust. These pockets range from 0.1 to $5 \mathrm{~mm}$ in crosssection. Many were clearly foraminifers (benthic and planktonic) that are now preserved as external molds; others are irregular and cannot be related to any fossil precursor. A few small "globigerinid" planktonic foraminifers occur within the pelagic limestone of these pockets, but these are not age-diagnostic. Calcareous nannofossils are common within these sediment pockets. Examination of many of these pockets yields an assemblage diagnostic of Zone CP10, indicating that the crust grew during the early Eocene.

Companion Sample 144-876A-1R-1, 8-17 cm, contains one small patch characterized by exclusively small planktonic foraminifers. These include Morozovella sp. cf. $M$. velascoensis, $M$. pusilla gr., Globanomalia compressa, questionable Parasubbotina pseudobulloides, Acarinina intermedia, Chiloguembelina sp., and abundant minute planktonics. This assemblage could be late Paleocene (Zone P4) in age.

A manganese crust and dendrite complex within companion Sample 144-876A-1R-1, 8-17 cm, contains numerous planktonic foraminifers of Zone P11-P12 (middle Eocene age). Species identified include Turborotalia possagnoensis, Pseudohastigerina danvillensis, "Globigerinatheka" senni, Acarinina pseudotopilensis, A. topilensis, and Globanomalina pseudoscitula. Benthics foraminifers include specimens of Nuttallides.

Sample 144-876A-1R-1, 17-22 cm, consists of a shallow-water carbonate and manganese crust breccia penetrated by a large (approximately $10 \times 10 \mathrm{~mm}$ ) burrow filled with pelagic carbonate. Rare Cretaceous planktonic foraminifers occur within the shallow-water clasts. Two generations of pelagic limestone occur in this sample.

Generation I of Sample 144-876A-1R-1, 17-22 cm, consists of a nannofossil foraminifer packstone filling the large burrow. Calcareous nannofossils include abundant Sphenolithus moriformis and S. radians; common Coccolithus pelagicus, Discoaster barbadiensis, and Reticulofenestra dictyoda; few Chiasmolithus solitus, C. grandis, and Reticulofenestra umbilica; and rare Cribrocentrum reticulatum. This assemblage is diagnostic for Subzone CP14a of middle Eocene age.

Generation II of Sample 144-876A-1R-1, 17-22 cm, consists of foraminifer packstone filling interparticle space in the bioclastic and manganese crust rudstone. The contact between the shallow-water carbonate clasts and the foraminifer packstone is clearly delineated by a thin manganese staining. Calcareous nannofossil assemblages in the breccia matrix include abundant Sphenolithus moriformis and $S$. radians; common Discoaster kuepperii, D. lodoensis, D. barbadiensis, and Ericsonia formosa; and few Tribrachiatus orthostylus, indicating Zone CP10 of early Eocene age. The foraminifer packstone matrix contains small-sized planktonic foraminifers progressively less phosphatized toward the top. Among useful species are Pseudohastigerina wilcoxensis, a fragment of possible "Globigerinatheka" senni, and Globanomalina pseudoscitula associated with common Thoracosphaera but without large Morozovella. It is assigned to Zone P8 (early Eocene age), based on its similarities with the fauna of Sample 144-876A-1R-1, 8-17 cm. This assignment is compatible with the calcareous nannofossil age determination.

Sample 144-876A-1R-1, 34-35 cm, consists of a bioclastic rudstone overlain by a nearly continuous manganese oxide crust that gives rise to a network of manganese dendrites. At least three generations of pelagic limestone occur in this thin section.

Generation I in Sample 144-876A-1R-1, 34-35 cm, consists of nannofossil foraminifer packstone to wackestone intercalated within the network of manganese dendrites. Planktonic foraminifers and calcareous nannofossils are incorporated within manganese dendrites, which results in the partial replacement of some foraminiferal walls and filling of foraminiferal chambers. Rare open voids within the dendrites and within one foraminiferal chamber are lined with isopachous equant cement that has been altered to phosphate. Phosphatic staining is also apparent on an echinoderm fragment. Common planktonic foraminifers occur within the dendrites. Species identified include Morozovella aragonensis, M. lehneri, M. crassata, Acarinina bullbrooki, A. spinuloinflata, A. pseudotopilensis, A. topilensis (r), "Globigerinatheka" senni, Globigerinatheka index (r), G. mexicana, Turborotalia possagnoensis, Igorina broedermanni, and Globanomalina pseudoscitula. This assemblage indicates the upper part of Zone P11. Calcareous nannofossils within this pelagic limestone include abundant Sphenolithus moriformis and Rhabdosphaera tenuis; common Rhabdosphaera scabrosa, Sphenolithus spiniger, S. radians, and Coccolithus pelagicus; and rare Nannotetrina cristata and Discoaster bifax. The presence of $D$. bifax and $N$. cristata and the absence of Chiasmolithus gigas suggests placement in Subzone CP13c. This is substantiated by the upper P11 zonal assignment. Benthic foraminifers include Lenticulina with predation traces, nodosariids, and buliminids.

Generation II in Sample 144-876A-1R-1, 34-35 cm, consists of nannofossil limestone filling an oval-shaped burrow penetrating Generation I (Fig. 6) and filling an irregular patch at the top of the thin section. Calcareous nannofossil assemblages are characterized by abundant Sphenolithus moriformis and Cyclicargolithus pseudogammation, common Sphenolithus pseudoradians, Dictyococcites bisecta, D. scrippsae, and Coccolithus pelagicus, few Dictyococcites daviesii and Discoaster tanii, and rare Cribrocentrum reticulatum. Chiasmolithus grandis is absent. This association indicates Subzone CP15a of late Eocene age.

Generation III in Sample 144-876A-1R-1, 34-35 cm, consists of an interparticle matrix of foraminiferal packstone within a shallowwater carbonate clast breccia. Breccia clasts are well preserved but coated with a rind of structureless manganese oxide. The matrix is partially phosphatized. Abundant, well-preserved nannofossils in this matrix include abundant Sphenolithus moriformis, S. radians, and Ericsonia formosa; common Discoaster barbadiensis, D. lodoensis, D. kuepperii, Sphenolithus orphanknollensis, and Rhabdosphaera tenuis; and rare Chiphragmalithus armatus. This assemblage, with the apparent absence of Tribrachiatus orthostylus, is suggestive of CP11. However, the occurrence of $C$. armatus indicates a more probable placement in CP10 of early Eocene age. The planktonic foraminifer assemblage within the phosphatic matrix is devoid of large forms but includes Pseudohastigerina wilcoxensis, Muricoglobigerina soldadoensis and Globanomalina pseudoscitula. This is early Eocene in age and is questionably assigned to Zone P8. This assemblage of smaller planktonic foraminifers is similar to other Zone P8 assemblages at this site (e.g., Sample 144-876A-1R-1, 4-8 cm), but lacks the abundant Thoracosphaera that characterize the latter assemblages.

Sample 144-876A-1R-1, 43-48 cm, consists of a cavity in the shallow-water carbonate that is filled with pelagic chalk. This sample contains a rich, well-preserved planktonic foraminifer fauna includ- 
ing Globoquadrina binaiensis, Globigerinoides sp., and representatives of the Globoquadrina tripartita group. This association indicates an early Miocene age. Benthic foraminifers include large costate lagenids, Eponides and Nuttalides. A similar cavity filling in Sample 144-876A-1R-1, 71-76 cm, contains calcareous nannofossils including Discoaster barbadiensis, D. strictus, and D. bifax, indicating Subzone CP14a of late middle Eocene age.

\section{Site 877}

Sample 144-877A-1R-1, 0-4 cm, consists of phosphatized shallowwater carbonate with a cavity fill of pelagic limestone. The pelagic limestone fill contains abundant, well-preserved calcareous nannofossils including Discoaster keupperi, D. lodoensis, and Tribrachiatus orthostylus. This association identifies Zone CP10 of early Eocene age. Planktonic foraminifers in this cavity filling are sparse and represented mainly by single chambers. One specimen of a chiloguembilinid is present.

Sample 144-877A-1R-1, 8-10 cm, consists of a piece of shallowwater carbonate with a small cavity filling of pelagic limestone. Several planktonics occur in this cavity filling, although the thin section is so thin at this point that they are visible only under cross polarizers. Several tests are incomplete, probably as a result of dissolution. Species identified include Morozovella conicotruncata, $M$. abundocamerata, M. pusilla, $M$. sp. cf. M. aequa, Muricoglobigerina mckannai, Globanomalina sp. cf. G. pseudomenardii, and Parasubbotina pseudobulloides. This assemblage suggests Subzone P3b-Zone P4 of late Paleocene age. Rare specimens within the microsparitic matrix of the shallow-water carbonate include Gansserina sp. cf. G. gansseri, Pseudotextularia elegans, and Globotruncana ventricosa, suggesting a Maastrichtian age (Erba et al., this volume). Sample 144-877A$2 \mathrm{R}-1,0-1 \mathrm{~cm}$, consists of almost pure nannofossil ooze that was carefully extracted from a manganese-lined vug on the upper surface of a piece of very pale brown (10YR 7/3) skeletal wackestone. The vug is subcircular in cross section with a diameter of approximately $5 \mathrm{~mm}$ and a depth of approximately $4 \mathrm{~mm}$. This ooze-filled boring lies at least $2.5 \mathrm{~m}$ below the upper surface of the shallow-water limestone. The nannofossil ooze contains an abundant, well-preserved nannofossil assemblage dominated by Ericsonia cava, Ericsonia ovalis, Ericsonia subpertusa, and Fasciculithus tympaniformis (s.s.). The presence of few Discoaster multiradiatus and common Camplyosphaera eodela, in addition to $F$. tympaniformis and $F$. billii, indicates biostratigraphic placement in Subzone CP8b of late Paleocene age. Interestingly, a smear slide prepared aboard ship from the upper $2 \mathrm{~mm}$ of this material lacks any Sphenolithus spp., whereas slides prepared subsequently on shore from the remaining (lower) material dug from this vug contain common $S$. primus (but no $S$. anarrhopus). Calcareous ooze was extracted from a sinuous boring (diameter approximately $5 \mathrm{~mm}$ ) that penetrates the interval $144-877 \mathrm{~A}-2 \mathrm{R}-1,6-10 \mathrm{~cm}$. This ooze differs from that in Sample 144-877A-2R-1, 0-1 cm, in only two respects: it is composed dominantly of micrite grains and the nannofossil preservation is moderate, with significant etching of many specimens. The high percentage of micrite grains may be an artifact of the technique used to extract the ooze from the narrow boring (reaming the hole with a straightened paper clip). Thus, micritic grains may have been derived from the shallow-water carbonate walls of the boring. However, the etching of the nannofossils is consistent with the presence of large quantities of micrite. The nannofossil assemblage in this sample is similar (although less rich and diverse) to that in Sample 144-877A-2R-1, 0-1 cm.

\section{MIT Guyot}

MIT Guyot is an isolated feature near the Wake Group. Site 878 is located at $27^{\circ} 19.14^{\prime} \mathrm{N}, 151^{\circ} 53.03^{\prime} \mathrm{E}$, on the northeastern part of the guyot near its southern edge. Unlike Limalok, Lo-En, and Wodejebato guyots, MIT Guyot lacks a thick pelagic cap. Its upper surface is characterized by a rough topography indicative of a karst surface developed in the shallow-water carbonates (van Waasbergen and Winterer, 1993). Manganese nodules and crusts from Holes 878 A and $878 \mathrm{C}$ were examined for this study. In Hole 878A, these nodules occur within a soupy ooze of late Pliocene(?) to late Miocene age (Premoli Silva, Haggerty, Rack, et al., 1993). Manganese nodules and crusts occur overlying shallow-water carbonates in Hole 878C.

Sample 144-878A-1R-1, 6-8 cm, consists of a nodule with a complex nucleus of heavily phosphatized pelagic sediments surrounded by thick manganese crusts. At least three generations of pelagic limestone are present. The first generation is represented by a very small patch of heavily phosphatized limestone with one specimen each of Heterohelix moremani and Planomalina praebuxtorfi. These species indicate a late Albian age, corresponding to the Rotalipora ticinensis/Rotalipora appenninica zonal boundary. A second generation is represented by one small patch of pelagic limestone with single specimens of Heterohelix sp. and Archaeoglobigerina sp. cf. A. cretacea. This indicates a Cretaceous age that is younger than Coniacian. A third generation of pelagic limestone, that constitutes the bulk of the matrix, contains numerous planktonic foraminifers that include Globotruncana tricarinata, Globotruncana linneiana, Globotruncanita elevata, Contusotruncana fornicata, Globigerinelloides ultramicrus, Marginotruncana coronata, Archaeoglobigerina blowi, and Heterohelix reussi. This association indicates the G. elevata Zone of early Campanian age. Sample 144-878A-1R-CC, 10-12 cm, is a flat nodule consisting of heavily phosphatized pelagic limestone penetrated by numerous burrows and coated by $5-7 \mathrm{~mm}$ of botryoidal manganese oxide. At least two generations of pelagic limestone have been identified. The majority of the pelagic limestone contains abundant, phosphate-replaced, calcareous nannofossils including Aspidolithus parcus parcus, Bukryaster hayi, Ceratolithoides verbeekii, Gephyrorhabdus coronadventis, and Marthasterites furcatus. This association indicates Subzone CC18c of early Campanian age. Planktonic foraminifers are abundant but there are few diagnostic cuts in the thin section. Species identified include Globotruncanita stuartiformis, Globotruncana bulloides, Globigerinelloides bollii, G. prairiehillensis, Heterohelix globulosa, and Rugoglobigerina sp. These taxa indicate a Campanian age. Burrows penetrating the groundmass include a slightly younger assemblage of phosphate-replaced calcareous nannofossils. This assemblage includes Aspidolithus parcus parcus, Ceratolithoides aculeus, Ceratolithoides verbeekii, and Eiffellithus eximius but lacks Quadrum sissinghii and Quadrum trifidum. This association identifies Zone CC20 of early Campanian age.

Sample 144-878C-1R-1, 5-10 cm, is a nodule composed of a complex nucleus with several generations of pelagic limestone and manganese crusts. The stratigraphic relationships within the nodule indicate that it is a composite of several, smaller nodules. Each of these smaller nodules contains a nucleus of pelagic limestone (Generations I and II). These smaller nodules were cemented together with additional pelagic limesione (Generations III and IV) and manganese crusts. The pelagic limestone of Generation I has been heavily phosphatized and penetrated by manganese dendrites. Microfossil preservation is generally poor and distinctly patchy. As a result, it is possible that more than one episode of pelagic sedimentation has been included in Generation I. Several patches contain Cretaceous planktonics including the recurrent species Heterohelix globulosa and Globigerinelloides messinae. In some of these patches, these recurrent species are associated with Globotruncana lapparenti, Hedbergella planispira, Globigerinelloides subcarinatus, and Heterohelix punctulata. This indicates an age not older than the late Santonian D. asymmetrica Zone and perhaps as young as the late Campanian Globorotruncanita calcarata Zone, based on the occurrence of $H$. punctulata. Another patch contains the recurrent species with Dicarinella asymmetrica and $G$. elevata. This patch belongs to the upper part of the $D$. asymmetrica Zone, and may be either very late Santonian or earliest Campanian in age.

One polygonal patch, whose shape suggests that it was a sedimentary clast, contains the recurrent species with a possible Globotrun- 


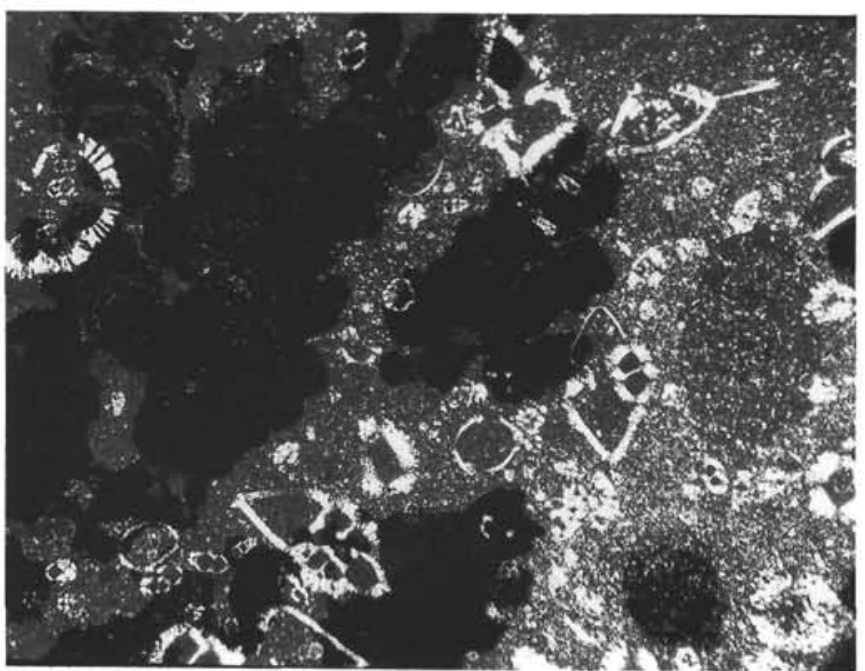

Figure 6. Ovoid burrow (right center) filled with upper Eocene (CP15a) nannofossil limestone penetrates middle Eocene (CP13) foraminifer packstone. Sample 144-876A-1R-1, 34-35 cm.

canita calcarata (Generation II). If this taxonomic determination is correct, then it indicates the G. calcarata Zone of late Campanian age. Abundant, but very poorly preserved, phosphatized calcareous nannofossils in this patch include Aspidolithus parcus parcus, Corollithion signum, Gephyrorhabdus coronadventis, Lithastrinus grillii, and a possible Ceratolithoides verbeekii. The last appearance of $L$. grillii occurs in Subzone CC22a (equivalent to the lower G. calcarata Zone). However, the occurrence of rare $C$. signum and G. coronadventis suggests an older age of $\mathrm{CC} 18-\mathrm{CC} 19$. This apparent discrepancy may be explained in one of two ways. Firstly, the last appearances of $C$. signum and $G$. coronadventis are not well documented in the Pacific region. It is possible that they have a significantly later extinction in the Pacific than in the Atlantic. Secondly, these species may be reworked into the younger ( $G$. calcarata Zone) sediment. This second hypothesis appears more likely, as these species are known from $\mathrm{CC} 18 \mathrm{c}$ material from this site (Table 1). Contrary to the shipboard determination, late Paleocene planktonic foraminifers are absent.

Generations III and IV consist of phosphate-replaced, pelagic limestone that cements the smaller nodules into a composite nodule. Generations III and IV contain fragments of broken manganese crust. Generation III contains abundant Thoracosphaera associated with common planktonic foraminifers of probable early Eocene age (Zone P8). The species identified are the same as in Zone P8 material from the other sites. Phosphate-replaced calcareous nannofossils from these patches include Discoaster lodoenisis, Discoaster germanicus, Discoaster kuepperi, and Camplyosphaera dela. This assemblage indicates Zone CP10-Subzone CP12a. The foraminiferal assignment limits this assemblage to Zones $\mathrm{CP} 10-\mathrm{CP} 11$ of early Eocene age. Generation IV contain relatively rich planktonic foraminifer assemblages with Acarinina spinuloinflata, A. bullbrooki, A. pseudotopilensis, A. topilensis, Morozovella caucasica, M. sp. cf. M. lehneri, and "Globigerinatheka" senni. This indicates the upper part of the middle Eocene Zone P11.

Sample 144-878C-1R-1, 12-18 cm, consists of a nodule with a nucleus of three, partially to heavily phosphatized pieces of pelagic limestone encrusted by manganese oxide. A few parts of the pelagic limestone nucleus contain visible planktonic foraminifers. In one area the foraminifers are still calcitic. Species present include Globotruncanita stuartiformis, G. elevata, Globotruncana arca, G. linneiana, G. bulloides, Heterohelix sp., Archaeoglobigerina cretacea, and a single specimen of Marginotruncana pseudolinneiana. This association of taxa cannot be older than late Santonian but it may be as young as earliest Campanian. Very rare planktonic foraminifers also occur within the manganese crust. The presence of Turborotalia possagnoensis indicates Zones P11-P12 of middle Eocene age.

\section{SUMMARY \\ Limalok Guyot}

Shallow-water carbonate sedimentation on Limalok Guyot ceased during the middle Eocene (Premoli Silva, Haggerty, Rack, et al., 1993). This was followed almost immediately by the initiation of pelagic sediment accumulation (Fig. 7). The inclusion of phosphatized and partially phosphatized clasts of shallow-water carbonate in the calcareous pelagic limestone matrix (Sample 144-871A-15H-CC, $10-13 \mathrm{~cm}$ ) indicates that the top of the dead carbonate platform was subjected to phosphatization and bioerosion before the deposition of the rudstone during the middle Eocene (Zone CP13). The relatively high species richness of the calcareous nannofossils in the rudstone matrix indicate open marine conditions were established over the guyot by the middle Eocene (Zone CP13). However, the abundance of pentaliths suggests that the depositional environment was relatively shallow and hemipelagic in character (Bybell and Gartner, 1972). Rudstone deposition may have been quite localized, as it was not evident in Hole 871C. However, this may be a function of incomplete recovery.

Deposition of a crust of manganese oxide followed Zone CP13 rudstone deposition, as evidenced by the crust in Sample 144-871 A-15H$\mathrm{CC}, 10-13 \mathrm{~cm}$, and by the manganese-encrusted clasts found in Generation I of Sample 144-871C-2R-1, 1-6 cm. This manganese crust may have protected the rudstone from subsequent phosphatization.

Significant bioerosion occurred following the manganese encrustation. Boring penetrated the rudstone (Sample 144-871A-15H-CC, $10-13 \mathrm{~cm}$ ) and the shallow-water carbonate (Sample 144-871C-2R-1, $1-6 \mathrm{~cm})$. The borings were filled by foraminifer grainstones of late middle to early late Eocene age (P14/CP14b and P15). The grainstone bore fillings are strongly skewed towards larger grain sizes, suggesting significant winnowing of the sediment before, or during, deposition.

The upper middle Eocene bore fillings were subjected subsequently to intense phosphatization followed by a brief period of manganese encrustation. The exact timing of these events is difficult to ascertain from Site 871 material. It is clear from the stratigraphic relationships in Sample 144-871C-2R-1, 1-6 cm, that phosphatization and manganese encrustation postdated the late middle Eocene deposition of the bore fillings and predated the late early Oligocene deposition of the (still calcareous) foraminifer grainstones of Generation III.

\section{Lo-En Guyot}

Sparse planktonic microfossils in a phosphatized clast in Sample 144-872B-4R-1, 13-16 cm, suggest that sedimentation at or near Site 872 began as early as Albian to earliest Cenomanian (Fig. 8). Rock dredges from the southern side of Lo-En Guyot, obtained during Moana Wave Cruise MW8805, yielded breccias with a calcareous matrix containing planktonic foraminifers of similar age range (Lincoln et al., 1993). The roundness of the clast and the absence of other material of similar age suggests that the clast may have been transported to Site 872 from elsewhere on the guyot top.

Pelagic sedimentation during the Coniacian and early Santonian filled cracks in the top of the volcanic substrate. The lower Santonian pelagic sediment also served as the matrix for a basalt and volcaniclastic pebble conglomerate. A second pulse of pelagic sedimentation during the late Santonian added to the matrix for this basalt and volcaniclastic pebble conglomerate. A third episode of pelagic sedimentation during the mid-Campanian (Subzone $\mathrm{CC} 18 \mathrm{c} / G$. elevata Zone) resulted in a similar conglomerate, although the pebbles in this unit were dominantly volcaniclastic. The mid-Campanian matrix of the volcaniclastic pebble conglomerate was still relatively uncemented in the late Campanian, as evidenced by the burrows filled with Zone CC20/G. ventricosa Zone pelagic sediment. The Santonian and 


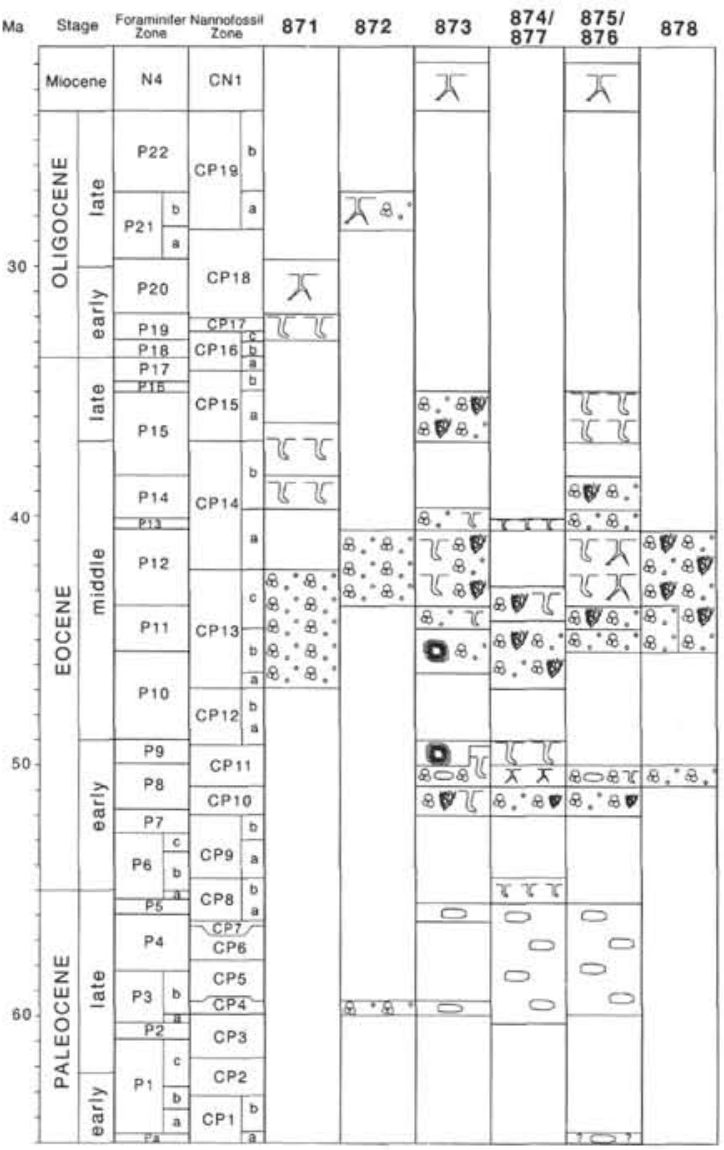

Figure 7. Summary of pelagic sediment preservation episodes during the early Cenozoic. Time scale after Berggren et al. (1985).

Campanian pelagic limestones were phosphatized thoroughly following their deposition. It is impossible to ascertain whether this was a single or multiple phosphatization event based on the scant evidence. It is clear, however, that profound phosphatization preceded the deposition of the lower upper Paleocene pelagic limestone in Sample 144-872B-4R-1, 13-16 cm.

The truncation of the manganese crust against the Paleocene pelagic limestone indicates that this crust was deposited and eroded before Zone CP4. The phosphatized limestone that comprises the matrix of the conglomerate is also truncated at its contact with the upper Paleocene limestone. In addition, a boring penetrating middle Eocene (CP14a/P12) chalk (Sample 144-872A-17H-CC, 0-5 cm) is filled with fragments of these Upper Cretaceous conglomerates (Premoli Silva, Haggerty, Rack, et al., 1993, "Site 872" chapter, fig. 12). This indicates that the conglomerate unit was broken up subsequent to its deposition and before the late Paleocene. Bioerosion is the most likely mechanism for this destructive activity. These clasts of conglomerate were incorporated in a breccia with a matrix of current-winnowed foraminifer grainstone to packstone during the middle Eocene. There is no record of subsequent sedimentation until the initiation of pelagic cap deposition in the late Oligocene (Subzone CP19a).

\section{Wodejebato Guyot}

Stratigraphic examination of the manganese oxide crusts and associated sediments from the five Wodejebato Guyot sites reveals a complex history of sedimentation during the Paleogene. Comparison of the lagoonal site (873), the combined inner perimeter ridge sites (874/877),

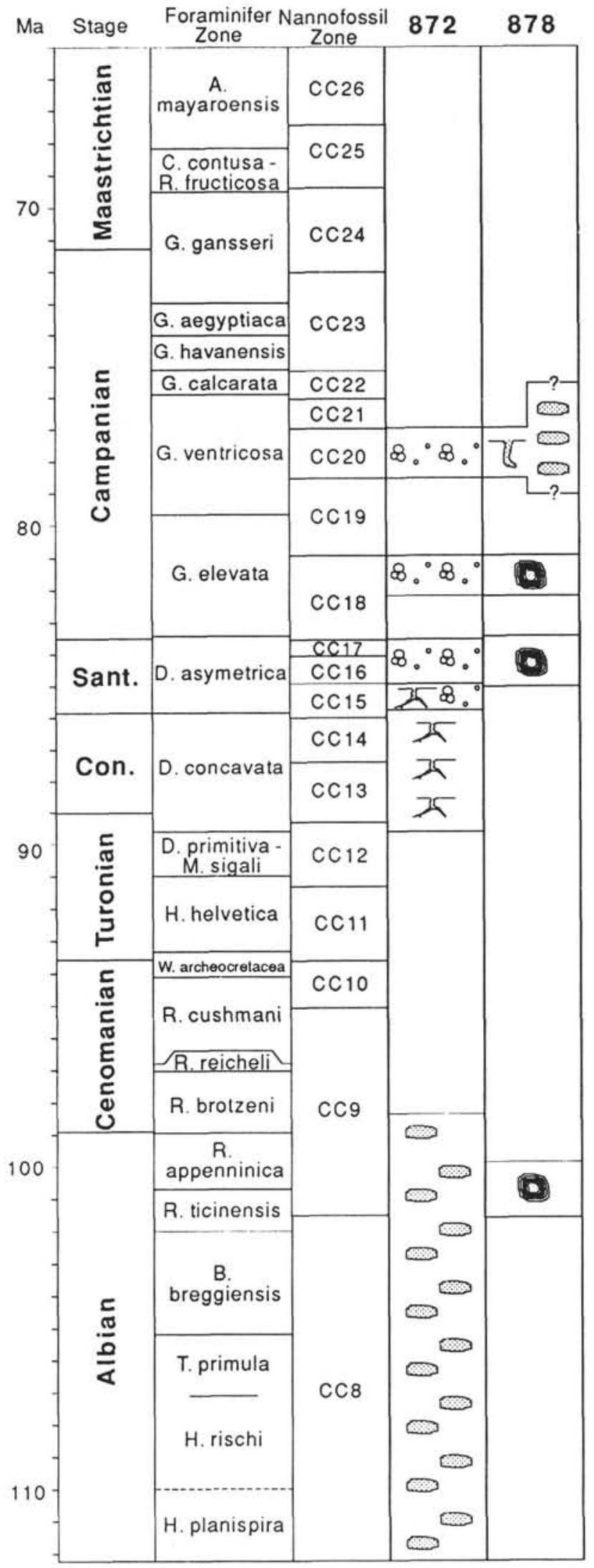

Figure 8. Summary of pelagic sediment preservation episodes during the Cretaceous. Symbols for microfacies as in Figure 7. Time scale as in Erba et al. (this volume). 
and the combined outer perimeter ridge sites $(875 / 876)$ reveals that the histories of these three areas are remarkably uniform. This is not unexpected, but does indicate that local effects (and even the variations in drilling and core recovery) are relatively unimportant. The following sequence of events is evident from the data collected.

Shallow-water carbonate deposition ceased on Wodejebato Guyot during the late Maastrichtian (Erba et al., this volume). The evidence of the oldest pelagic sedimentation following the drowning event are foraminifer nannofossil limestone clasts of late Paleocene age. Clasts from the inner and outer perimeter ridge sites are so heavily phosphatized that only ghosts of planktonic foraminifers survived the mineralization process. These clasts yield generalized ages of Zones P3 to P4 (Fig. 7). Phosphatization was evidently less intense at Site 873, as both calcareous nannofossils and foraminifers with calcitic shells are preserved. These indicate that the clasts were derived from two generations of pelagic limestone (CP4/P3b and CP8a/P4). Many of the older clasts bear rims of phosphatized, isopachous radial or fibrous cement (e.g., Sample 144-873A-2R-1, 0-2 cm), whereas the younger clasts lack these rims. This suggests a cementation event occurred in the late Paleocene between Zone CP4 and Subzone CP8a. Both generations of upper Paleocene clasts bear rims of manganese oxide.

Given the advanced state of phosphatization of the upper Paleocene clasts at the perimeter ridge sites, the occurrence of uppermost Paleocene (Subzone CP8b) nannofossil ooze in Sample 144-877A$2 \mathrm{R}-1,0-1 \mathrm{~cm}$, is significant. This ooze fills a boring that penetrates into the underlying shallow-water carbonate for a distance of at least $10 \mathrm{~cm}$. The ooze shows no evidence of phosphatization or even normal lithification. It is probable that this ooze was buried at sufficient depth (in this case, at least $2.5 \mathrm{~m}$ ) below the sediment-water interface to avoid phosphatization. The boring filled by this ooze is lined with manganese oxide. This fact, combined with the presence of manganese oxide rims on Subzone CP8a clasts from Site 873, suggests that an episode of manganese deposition occurred sometime late in Subzone CP8a or early in Subzone CP8b.

The next pulse of pelagic sedimentation occurred during the early Eocene. This pulse of sedimentation was preceded by, or accompanied by, significant bioerosion. Rudstones composed of shallowwater carbonate clasts were deposited at all of the Wodejebato sites during the early Eocene (Zone CP10). A boring filled with similar Zone CP10 pelagic sediment was found at Site 873. A second pulse of bioerosion and pelagic sedimentation occurred slightly later in the early Eocene (Zones CP11/P8). These two episodes were separated by the deposition of manganese crusts and dendrites, as is clearly illustrated in Sample 144-876A-1R-1, 12-17 cm. This crust formed during the later part of Zone CP10, as is evidenced by Samples 144-874B-1R-1, 7-10 cm, and 144-876A-1R-1, 12-17 cm.

The next pulse of bioerosion and pelagic sedimentation occurred during the middle Eocene. The best preserved assemblages (e.g., Sample 144-876A-1R-1, 34-35 cm; Generation I) yield a late middle Eocene (CP13b/P11) age for this episode. Others yield more generalized age assignments of Zone CP13 or Zones P10-P11. This episode of sedimentation is followed by a renewal of manganese oxide deposition. This includes the formation of manganese crusts and dendrite networks as well as accretion of manganese nodules (e.g., Sample 144-873A-1R-1, 21-25 cm). This event is best dated as Zone P11/ Subzone CP13c, based on the evidence of Sample 144-876A-1R-1, $34-35 \mathrm{~cm}$ (Generation I). The presence of phosphatic, isopachous, equant cement that lines open voids in the dendrite network and fills a foraminifer chamber in this sample indicates a brief episode of phosphatization occurred during this part of the middle Eocene.

The next episode of bioerosion and pelagic sedimentation occurred almost immediately after this manganese event. Cavity fill, boring fill, and rudstone matrix of middle Eocene Zone P12 and Subzone CP14a occur at all of the Wodejebato sites. This episode may have continued throughout Subzone CP14a (= Zones P12 and P13), although evidence from Site 874 suggests an hiatus between the lower part of Zone P12 and P13 (Fig. 7). This episode (or episodes) of bioerosion and pelagic sedimentation ended in the late middle Eocene (Zone P14/Subzone CP14b) with the deposition of another generation of manganese crusts and dendrites, as evidenced in Sample 144-875C-1M-1, 7-12 cm (Generation I).

The final episode of Paleogene bioerosion and pelagic sedimentation occurred during the late Eocene (Subzone CP15a). This generation, represented in Sample 144-873A-1R-1, 0-5 cm, consists of pelagic limestone filling cavities and the interstices of manganese dendrites. Indirect evidence suggests that this generation of pelagic limestone is overlain by a continuous, relatively soft, manganese crust that was destroyed by drilling processes (Premoli Silva, Haggerty, Rack, et al., 1993). Deposition of the pelagic cap sequence of foraminifer oozes began in the early Miocene (Zones CN1/N4).

\section{MIT Guyot}

Carbonate platform sedimentation on MIT Guyot ended following the Biticinella breggiensis Zone of late Albian age (Erba et al., this volume). Pelagic sedimentation began shortly after platform drowning, as evidenced by the presence of pelagic limestone whose age straddles the Rotalipora ticinensis/Rotalipora appenninica zonal boundary (Sample 144-878A-1R-1, 6-8 cm).

Pelagic sedimentation and preservation through the rest of the Cretaceous was episodic (Fig. 8). The reconstruction of this history is complicated by the uncertainty of some biostratigraphic assignments because of sparse, poorly preserved assemblages and possible reworking. Planktonic foraminiferal evidence indicates that the oldest pulse of Late Cretaceous pelagic sedimentation was during the late Santonian to earliest Campanian (upper D. asymmetrica Zone). A second pulse of pelagic sedimentation occurred during the early Campanian ( $G$. elevata Zone/Subzone CC18c). A third episode of pelagic sedimentation occurred later in the early late Campanian, as evidenced by Zone $\mathrm{CC} 20$ calcareous nannofossils filling burrows in Sample 144-878A-1R-CC, $10-12 \mathrm{~cm}$. A fourth episode of pelagic sedimentation may have occurred later in the Campanian. Planktonic foraminiferal evidence suggests a late Campanian $(G$. calcarata Zone) age, whereas the calcareous nannofossil evidence suggests a late early Campanian (CC18-CC19) age. This apparent discrepancy may be caused by reworking of the nannofossils.

The evidence from Sample 144-878C-1R-1, 5-10 cm, indicates that the Cretaceous pelagic limestones were fragmented and used as the nuclei of small manganese nodules at some time before the early Eocene. These small manganese nodules were enveloped by pelagic limestone during early Eocene (P8/CP10-CP11) and middle Eocene (upper P11) episodes of sedimentation (Fig. 7). Rare planktonic foraminifers within the outer manganese crust of Sample 144-878C-1R$1,12-18 \mathrm{~cm}$, yield a similar middle Eocene (P11-P12) age. It is clear that the latter (P11-P12) was deposited during the formation of the manganese crust, whereas the occurrence of the former (upper P11) within the nodule suggests that it preceded outer crust formation. Thus, these appear to represent two distinct episodes that were closely spaced in time. All of the Cretaceous and Eocene sediment is heavily phosphatized. This replacement may have been the result of either single or multiple episodes of phosphatization.

\section{DISCUSSION}

The manganese-encrusted hardgrounds and associated sediments examined in this study record the histories of the four guyots from the time they subsided below the photic zone until the initiation of pelagic cap accumulation. The results summarized above indicate that pelagic sediment accumulation, manganese oxide deposition, and phosphatization occurred as a series of episodic events with an order that can be deciphered from careful study of the microstratigraphies of the hardgrounds and associated sediments. Comparison of the results from different guyots indicates that many of these events are correlative across the entire study area. 


\section{Patterns of Pelagic Sediment Accumulation}

With the exception of rare planktonic microfossils within the shallow-water carbonate sequences (Erba et al., this volume), the record of Cretaceous pelagic sedimentation from the Leg 144 sites is limited to Lo-En and MIT guyots. Pelagic sedimentation on both guyots begins in the Albian (Fig. 8). The intensely phosphatized nature of the small sample of this material from Lo-En Guyot limits biostratigraphic resolution to the stage level. Similar material from MIT Guyot yields a late late Albian age. These may or may not be actually the same age. A Coniacian to early Santonian episode of pelagic sedimentation, preserved in a fracture in the basalt edifice of Lo-En Guyot, has no observed counterpart on MIT Guyot. The remainder of the Late Cretaceous history of pelagic sedimentation on these two guyots, however, appears to have been identical. Three episodes of calcareous pelagic sedimentation are recorded from both guyots: late Santonian (upper $D$. asymmetrica Zone), early Campanian (G. elevata Zone/Subzone CP18c), and early late Campanian (Subzone CC20). This exact correspondence is striking, especially as Lo-En and MIT guyots are separated by more than $15^{\circ}$ latitude and $10^{\circ}$ longitude.

The late Maastrichtian drowning of Wodejebato placed a third guyot within the pelagic realm during the Paleocene. A pulse of pelagic sediment accumulation during the early late Paleocene (Subzone $\mathrm{P} 3 \mathrm{~b} / \mathrm{CP} 4)$ was recorded on Lo-En and Wodejebato guyots. Two later Paleocene pulses (P4/CP8a and CP8b) were preserved only on Wodejebato Guyot. The former may not have been observed on Lo-En and MIT guyots because of the small number of samples available. The latter (CP8b) pulse was recorded only at Site 877 , where the sediment was preserved in a boring at least $2.5 \mathrm{~m}$ below the top of the shallow-water carbonate sequence. Sediment deposited during this CP8b episode may have had a much more extensive distribution, but was removed from all but the most protected areas by subsequent current activity.

Eocene pelagic sediment accumulation was also episodic in nature. The precise timing of these accumulation pulses is partially blurred by uncertainties in the biostratigraphic assignment of some samples because of small size and poor preservation. The early Eocene was characterized by two distinct pulses of pelagic sediment accumulation during Zones CP10 and CP11. These pulses were separated in time by a brief hiatus during which significant manganese accumulation occurred. The record for the middle Eocene is less clear. Evidence from the most precisely dated sediments suggests one minor and two major pulses of middle Eocene sediment accumulation. A major pulse during the middle middle Eocene (approximately CP13b) is recorded on Limalok, Wodejebato, and MIT guyots. A second major pulse during the middle middle Eocene (approximately P12-P13/CP14a) was preserved on Lo-En, Wodejebato, and MIT guyots. These two pulses were separated by a brief hiatus (corresponding to part of CP13c), during which manganese crust deposition and minor phosphatization occurred. A minor episode of pelagic sediment accumulation occurred during the late middle Eocene (P14/CP14b), as recorded on Limalok and Wodejebato guyots. The last pulse of pelagic sediment accumulation occurred during the late middle Eocene (CP15a) on Limalok and Wodejebato guyots. No further pelagic sediment accumulated until the initiation of pelagic cap formation.

The correlative, episodic nature of the pelagic sediment record on the guyots suggests that its accumulation, at least in part, is the result of regional oceanographic effects. These accumulation episodes may reflect regional productivity events. However, there are two lines of evidence that suggest that current velocity across the guyot surface is the controlling factor. Many of the microfossil assemblages exhibit strong evidence of winnowing during their accumulation. Current winnowing of sediments on guyots is a well known phenomenon, and is most prevalent on guyots whose summit plateaus are at depths less than $2000 \mathrm{~m}$ (Levin and Nittrouer, 1987). In addition, pelagic sediment accumulation on all four guyots invariably occurs in cavities, burrows, rudstone interparticle space, or manganese dendrite interstices. All these microenvironments would be sheltered, to some degree, from subsequent current activity that would otherwise remobilize any deposited pelagic sediment. Given this hypothesis, it appears likely that pelagic sediment accumulated only when current velocities in the intermediate-water mass that bathed the guyot top was low enough to allow long-term preservation of sediment trapped in the sheltered microenvironments. The guyot summits would have been swept clean during periods of higher current velocities. These conditions would be conducive for the deposition of manganese crusts.

\section{Manganese Oxide Deposition}

The deposition of manganese oxide crusts and dendrites appears to have been episodic in the study area, with at least five pulses of manganese growth occurring during the Late Cretaceous and Paleogene. The oldest episode of manganese deposition, recorded on LoEn and MIT guyots, is poorly constrained in time. Evidence from Lo-En Guyot indicates that crust and nodule formation postdated the early late Campanian (CC20) and predated the early late Paleocene (CP4). The second episode of manganese deposition unequivocally occurs only on Wodejebato Guyot. There, this episode is precisely dated as upper Zone CP10 of middle early Eocene age. A third pulse of manganese crust growth occurred during the middle middle Eocene. Although recorded on Limalok, MIT, and Wodejebato guyots, this episode is best dated on the latter, where stratigraphic relationships indicate that it occurred at the coincident P11-P12 and CP13$\mathrm{CP} 14$ boundaries. A fourth episode of manganese deposition occurred during the late middle Eocene (P14/CP14b), as recorded on Limalok and Wodejebato guyots. The final pulse of manganese crust formation is poorly constrained in time. Stratigraphically, this crust lies between the youngest hardground carbonate and the oldest pelagic cap chalk on Limalok and Wodejebato. On the former, it has a maximum span of upper middle Eocene (CP14b) to middle lower Oligocene (P19/ $\mathrm{CP} 18$ ). On the latter, the manganese crust has a maximum span of upper Eocene (CP15b) to lowest Miocene (N4/CN1).

\section{Phosphatization Events}

Partial or total phosphatic replacement of calcareous pelagic and shallow-water platform sediments is evident at sites on all four guyots. At least five episodes of phosphatization can be recognized. All of the Cretaceous pelagic sediment from Lo-En and MIT guyots has been totally converted to phosphate. Assuming that this was the result of one event, it must have occurred after the early late Campanian (CC20) and before the early late Paleocene (CP4) deposition of the (still calcareous) nannofossil limestone in Sample 144-872B-4R-1, 13-16 cm. Hein et al. (1993) report a minor phosphatization event dated as 71 m.y. from the central western Pacific. This event would well explain the phosphate-replacement evident in the Lo-En and MIT Cretaceous pelagic sediment. Clasts of upper Paleocene pelagic sediment from Wodejebato are partially to totally replaced by phosphate, whereas the Eocene matrix they are enclosed in is unmineralized. This indicates an episode of phosphatization that occurred during the latest Paleocene (CP8b) or earliest Eocene (CP9). The fact that the lower upper Paleocene $(\mathrm{P} 3 \mathrm{~b} / \mathrm{CP} 4)$ pelagic sediment from Lo-En is unmineralized suggests that this may have been a very localized event.

Three episodes of minor phosphate replacement of planktonic microfossils and rim cements occurred during the middle and late Eocene. These include an early middle Eocene (approximately P10/ CP12) event on Limalok, Wodejebato, and MIT(?); a middle middle Eocene (approximately P11/CP13c) event on Wodejebato; and late middle to early late Eocene (approximately P15/CP14b-CP15a) event on Limalok and Wodejebato. The early middle Eocene event corresponds approximately to the Horizon $\mathrm{A}^{\mathrm{c}}$ biosiliceous productivity burst. McGowran (1989) linked this event to a sharp cooling pulse that stimulated increased oceanic upwelling. This increased upwelling may 
have provided the increased nutrient flux necessary to promote phosphatization on the guyot summits. The later Eocene events may have been more localized events in the Marshall Islands area.

The final phosphatization event is recorded from Limalok Guyot. Borings in shallow-water carbonate are partially filled with pelagic limestone (Sample 144-871C-2R-1, 1-6 cm; Generation I) of late middle Eocene (P14/CP14b) age. The pelagic infillings and the shallowwater carbonate have been totally replaced by phosphate. The remaining open space in the borings contains unmineralized pelagic chalk of early Oligocene (P19/CP18) age. The pervasive phosphatization of the Eocene pelagic limestone and its host rock suggest a major phosphatization event. Hein et al. (1993) identified such a major event, in the western Pacific, spanning the Eocene/Oligocene boundary (34-39 m.y.). The postulated age of this event corresponds almost exactly with the biostratigraphically inferred date from Limalok Guyot.

\section{CONCLUSIONS}

One of the principle objectives of Leg 144 was to constrain the timing of carbonate platform drowning on the various guyots. The age information derived from the manganese-encrusted hardgrounds provides a minimum date for platform drowning on three of the five guyots drilled on Leg 144. The youngest shallow-water carbonate sediment on Limalok Guyot (Site 871) was dated as middle Eocene based on biostratigraphically diagnostic larger benthic foraminifers (Premoli Silva, Haggerty, Rack, et al., 1993). Pelagic limestone in the overlying manganese-encrusted hardground yields an age of early middle Eocene (Zone CP13). The maximum hiatus possible between the cessation of platform sedimentation and the initiation of hardground formation is approximately $4 \mathrm{~m} . \mathrm{y}$., although it is probably significantly less. Shallow-water carbonate sedimentation on Wodejebato Guyot (Sites 873-877) ceased during the late, possibly latest, Maastrichtian. The onset of pelagic sedimentation, recorded in manganese-encrusted hardgrounds, is dated as early late Paleocene using planktonic foraminifers (Subzone P3b) and calcareous nannofossils (Zone CP4). The maximum hiatus between shallow-water and pelagic sedimentation is approximately $8 \mathrm{~m} . y$., although uncertainties in the dating of the youngest platform carbonates suggest it is significantly less. The drowning of the shallow-water platform on MIT Guyot is the most tightly constrained. The youngest shallow-water carbonate (Biticinella breggiensis Zone; Erba et al., this volume) and the oldest pelagic sediment (Rotalipora ticinensis/Rotalipora appenninica zonal boundary) are late Albian in age. The stratigraphic hiatus indicated is approximately $1 \mathrm{~m} . \mathrm{y}$.

Detailed examination of manganese crusts and nodules, using lithostratigraphic and biostratigraphic examination of thin sections, has revealed a complex history of episodic pelagic sediment accumulation, manganese deposition, and phosphatization on the guyot summits during the Late Cretaceous and Paleogene. Fourteen distinct episodes of pelagic sediment accumulation were documented from the Albian through Eocene. Five occurred during the Albian to Campanian; four of these are documented from Lo-En and MIT guyots. Three pulses of pelagic sediment accumulation occurred during the Paleocene, of which one was recorded on Wodejebato and Lo-En guyots. At least seven episodes of pelagic sediment accumulation occurred during the Eocene. Five of these are recorded on more than one guyot. The winnowed nature of many of these pelagic sediments, and their preservation only in sheltered microenvironments, suggests that they accumulated during times of low current velocities in the intermediatewater mass that bathed the guyot summits. At least five episodes of manganese crust and dendrite growth are documented from the guyot hardgrounds. The timing of the oldest is poorly constrained as early late Campanian to early late Paleocene. The other four are tightly constrained in time to short periods in the Eocene. These Eocene manganese crusts alternate with periods of pelagic sediment accumulation. It is suggested that these crusts were deposited during periods of intensified current activity over the guyot summits.
Five episodes of phosphatization were deduced from the sedimentary record of the guyots. The latest Eocene to early Oligocene event corresponds precisely with a period of major phosphogenesis for the Pacific, as documented by Hein et al. (1993). The late Cretaceous to early Paleogene event may correspond to the 71 m.y. "minor" event of Hein et al (1993). A third event that occurred during the early middle Eocene seems to correspond temporally with the deposition of Horizon $\mathrm{A}^{\mathrm{c}}$ biosiliceous sediments. It is suggested that intensified upwelling during this time resulted in a minor phosphatization event on Limalok, Wodejebato, and MIT guyots. Two other minor phosphatization events during the middle to early late Eocene may have been localized events related to guyot effect upwelling in the Marshall Islands.

Finally, we think that our methods of microstratigraphic investigation offer the potential to examine facies that are widespread in the world's ocean system but have proved difficult to study in the past. The wealth of data we have extracted from these thin, condensed sequences suggests that these microstratigraphic methods may prove to be of some importance in future paleoceanographic work.

\section{ACKNOWLEDGMENTS}

We wish to thank Captain Anthony Ribbens and the entire crew of the $S E D C O / B P 471$ for their help in providing an excellent and comfortable voyage. Our special thanks are extended to the drilling crew, whose expertise and dedication provided us with the material for this study. We thank our scientific colleagues for their stimulating discussion on land and at sea. We thank Jodi Norris, Im Chul Shin, Chris Rudnick, and Claire Larson for their help in sample and manuscript preparation. The manuscript was reviewed by Sherwood W. Wise, Jr., and William G. Siesser. Their comments significantly improved the final product. We also thank the editorial staff at ODP, who showed us the error of our ways. Thanks are also extended to Mary Anne Holmes, who proofread the final draft. Funding for this study was provided to DKW by JOI/USSAC.

\section{REFERENCES ${ }^{*}$}

Bathurst, R.G.C., 1966. Boring algae, micrite envelops and lithification of molluscan biosparites. Geol. J., 5:15-32.

, 1975. Carbonate Sediments and Their Diagenesis: Amsterdam (Elsevier).

Berggren, W.A., Kent, D.V., and Flynn, J.J., 1985. Jurassic to Paleogene: Part 2. Paleogene geochronology and chronostratigraphy. In Snelling, N.J. (Ed.), The Chronology of the Geological Record. Geol. Soc. London Mem., 10:141-195.

Berggren, W.A., and Miller, K.G., 1988. Paleogene tropical planktonic foraminiferal biostratigraphy and magnetobiochronology. Micropaleontology, $34: 362-380$.

Bukry, D., 1975. Coccolith and silicoflagellate stratigraphy, northwestern Pacific Ocean, Deep Sea Drilling Project Leg 32. In Larson, R.L., Moberly, R., et al., Init. Repts. DSDP, 32: Washington (U.S. Govt. Printing Office), 677-701.

Bybell, L., and Gartner, S., 1972. Provincialism among mid-Eocene calcareous nannofossils. Micropaleontology, 18:319-336.

Hay, W.W., 1970. Calcareous nannofossils from cores recovered on Leg 4. In Bader, R.G., Gerard, R.D., et al., Init. Repts. DSDP, 4: Washington (U.S. Govt. Printing Office), 455-501.

Hein, J.R., Yeh, H.-W., Gunn, S.H., Sliter, W.V., Benninger, L.M., and Wang, C.-H., 1993. Two major Cenozoic episodes of phosphogenesis recorded in equatorial Pacific seamount deposits. Paleoceanography, 8:293-311.

Levin, L.A., and Nittrouer, C.A., 1987. Textural characteristics of sediments on deep seamounts in the Eastern Pacific Ocean between $10^{\circ} \mathrm{N}$ and $30^{\circ} \mathrm{N}$. In Keating, B.H., Fryer, P., Batiza, R., and Boehlert, G.W. (Eds.), Seamounts, Islands, and Atolls. Geophys. Monogr., Am. Geophys. Union, 43:187-203.

\footnotetext{
- Abbreviations for names of organizations and publications in ODP reference lists follow the style given in Chemical Abstracts Service Source Index (published by American Chemical Society).
} 
Lincoln, J.M., Pringle, M.S., and Premoli-Silva, I., 1993. Early and Late Cretaceous volcanism and reef-building in the Marshall Islands. In Pringle, M.S., Sager, W.W., Sliter, W.V., and Stein, S. (Eds.), The Mesozoic Pacific: Geology, Tectonics, and Volcanism. Geophys. Monogr., Am. Geophys. Union, 77:279-305.

Loeblich, A.R., Jr., and Tappan, H., 1966. Annotated index and bibliography of the calcareous nannoplankton, I. Phycologia, 5:81-216.

, 1968. Annotated index and bibliography of the calcareous nannoplankton, II. J. Paleontol., 42:584-598.

, 1969. Annotated index and bibliography of the calcareous nannoplankton, III. J. Paleontol., 43:568-588.

, 1970a. Annotated index and bibliography of the calcareous nannoplankton, IV. J. Paleontol.,44:558-574.

$-1970 \mathrm{~b}$. Annotated index and bibliography of the calcareous nannoplankton, V. Phycologia, 9:157-174.

, 1971. Annotated index and bibliography of the calcareous nannoplankton, VI. Phycologia, 10:315-339.

, 1973. Annotated index and bibliography of the calcareous nannoplankton, VII. J. Paleontol., 47:715-759.

Martini, E., 1971. Standard Tertiary and Quaternary calcareous nannoplankton zonation. In Farinacci, A. (Ed.), Proc. 2nd Int. Conf. Planktonic Microfossils Roma: Rome (Ed. Tecnosci.), 2:739-785.

McGowran, B., 1989. Silica burp in the Eocene Ocean. Geology, 17:857-860.

Okada, H., and Bukry, D., 1980. Supplementary modification and introduction of code numbers to the low-latitude coccolith biostratigraphic zonation (Bukry, 1973; 1975). Mar. Micropaleontol., 5:321-325.

Olsson, R.K., Hemleben, C., Berggren, W.A., and Liu, C., 1992. Wall texture classification of planktonic Foraminifera Genera in the lower Danian. $J$. Foraminiferal Res., 22:195-213.

Perch-Nielsen, K., 1985. Cenozoic calcareous nannofossils, In Bolli, H.M., Saunders, J.B., and Perch-Nielsen, K. (Eds.), Plankton Stratigraphy: Cambridge (Cambridge Univ. Press), 427-554.

Premoli Silva, I., and Boersma, A., 1988. Atlantic Eocene planktonic foraminiferal historical biogeography and paleohydrographic indices. Palaeogeogr., Palaeoclimatol., Palaeoecol., 67:315-356.

Premoli Silva, I., Haggerty, J., Rack, F., et al., 1993. Proc. ODP, Init. Repts., 144: College Station, TX (Ocean Drilling Program).

Premoli Silva, I., and Sliter, W.V., 1994. Cretaceous planktonic foraminiferal biostratigraphy and evolutionary trends from the Bottaccione Section, Gubbio, Italy. Palaeontogr. Ital., 81:2-90.

Romein, A.J.T., 1979. Lineages in early Paleogene calcareous nannoplankton. Utrecht Micropaleontol. Bull., 22:1-231.

, 1984a. Bibliography and taxa of calcareous nannoplankton-III. INA Newsl., 6:6-37.

, 1984b. Bibliography and taxa of calcareous nannoplankton-IV. INA Newsl., 6:55-61.

1985a. Bibliography and taxa of calcareous nannoplankton- $-\mathrm{V}$. INA Newsl., 7:5-28.

1985b. Bibliography and taxa of calcareous nannoplankton-VI. INA Newsl., 7:122-145.

1986. Bibliography and taxa of calcareous nannoplankton-VIII. INA Newsl., 8:66-87.

1987. Bibliography and taxa of calcareous nannoplankton-IX. INA Newsl., 9:8-29.

1987. Bibliography and taxa of calcareous nannoplankton-X. INA Newsl., 10:79-105.

, 1988. Bibliography and taxa of calcareous nannoplankton-XI. INA Newsl., 10:7-28.

1988. Bibliography and taxa of calcareous nannoplankton-XII. INA Newsl., 10:60-88.

1989. Bibliography and taxa of calcareous nannoplankton-XIII. INA Newsl., 11:6-23.

Toumarkine, M., and Luterbacher, H., 1985. Paleocene and Eocene planktic foraminifera. In Bolli, H.M., Saunders, J.B., and Perch-Nielsen, K. (Eds.), Plankton Stratigraphy: Cambridge (Cambridge Univ. Press), 87-154.

, 1979a. Bibliography and taxa of calcareous nannoplankton. INA Newsl., 1:AB1-B27.

1979b. Bibliography and taxa of calcareous nannoplankton. INA

Newsl., 1:ABV1-B42.

1980a. Bibliography and taxa of calcareous nannoplankton. INA Newsl., 2:5-34.

1980b. Bibliography and taxa of calcareous nannoplankton. INA Newsl., 2:43-81. 1981a. Bibliography and taxa of calcareous nannoplankton. INA

Newsl., 3:4-41.

1981b. Bibliography and taxa of calcareous nannoplankton. INA

Newsl., 3:51-86.

, 1982a. Bibliography and taxa of calcareous nannoplankton. INA

Newsl., 4:7-50.

, 1982b. Bibliography and taxa of calcareous nannoplankton. INA

Newsl., 4:65-96.

1983. Bibliography and taxa of calcareous nannoplankton. INA

Newsl., 5:4-13.

van Waasbergen, R.J., and Winterer, E.L., 1993. Summit geomorphology of western Pacific guyots. In Pringle, M.S., Sager, W.W., Sliter, W.V., and Stein, S. (Eds.), The Mesozoic Pacific: Geology, Tectonics, and Volcanism. Geophys. Monogr., Am. Geophys. Union, 77:335-366.

\section{Date of initial receipt: 3 February 1994 \\ Date of acceptance: 28 July 1994 \\ Ms 144SR-017}

\section{APPENDIX}

\section{Planktonic Microfossils Cited in This Report}

\section{Calcareous Nannofossils}

Cretaceous Species

Ahmuellerella octoradiata (Gorka, 1957) Reinhardt, 1964

Ahmuellerella regularis (Gorka, 1957) Verbeek, 1977

Arkhangelskiella specillata Vekshina, 1959

Aspidolithus parcus expansus (Wise and Watkins in Wise, 1983) Perch-

Nielsen, 1984

Aspidolithus parcus parcus (Stradner,1963) Noel, 1969

Bukryaster hayi (Bukry, 1969) Prins and Sissingh (1977)

Ceratolithoides aculeus (Stradner, 1961) Prins and Sissingh (1977)

Ceratolithoides verbeekii Perch-Nielsen (1979)

Chiastozygus amphipons (Bramlette and Martini, 1964) Gartner (1968)

Chiastozygus litterarius (Gorka, 1957) Manivit (1971)

Chiastozygus propagulis Bukry (1969)

Chiastozygus quadriperforatus Gartner (1968)

Corollithion exiguum Stradner (1961)

Corollithion signum Stradner (1963)

Cretarhabdus conicus Bramlette and Martini (1964)

Cretarhabdus schizobrachiatus (Gartner, 1968) Bukry (1969)

Cribrosphaerella ehrenbergii (Arkhangelsky, 1912) Deflandre (1952)

Eiffellithus eximius (Stover, 1966) Perch-Nielsen (1968)

Eiffellithus turriseiffelii (Deflandre, 1954) Reinhardt (1965)

Eprolithus floralis (Stradner, 1962) Stover (1966)

Gartnerago costatum (Gartner, 1968) Bukry (1969)

Gartnerago obliquum (Stradner, 1963) Noel (1970)

Gephyrorhabdus coronadventis (Reinhardt, 1966) Hill (1976)

Glaukolithus bicrescenticus (Stover, 1966)

Glaukolithus diplogrammus (Deflandre, 1954) Reinhardt (1964)

Lithastrinus grillii Stradner (1962)

Lithastrinus septenarius Forchheimer (1972)

Lithraphidites carniolensis Deflandre (1963)

Lucianorhabdus cayeuxii Deflandre (1959)

Manivitella pemmatoidea (Deflandre, 1965) Thierstein (1971)

Marthasterites furcatus (Deflandre, 1954) Deflandre (1959)

Microrhabdulus decoratus Deflandre (1959)

Micula concava (Stradner, 1960) Verbeek (1976)

Micula cubiformis Forchheimer (1972)

Micula decussata Vekshina (1959)

Nannoconus farinacciae Bukry (1969)

Nannoconus truittii Brönnimann (1955)

Placozygus fibuliformis (Reinhardt, 1964) Hoffman (1970)

Prediscosphaera cretacea (Arkhangelsky, 1912) Gartner (1968)

Prediscosphaera honjoi Bukry (1969)

Prediscosphaera intercisa (Deflandre, 1954) Shumenko (1976)

Prediscosphaera ponticula (Bukry, 1969) Perch-Nielsen (1984)

Prediscosphaera spinosa (Bramlette and Martini, 1964) Gartner (1968)

Reinhardtites anthophorus (Deflandre, 1959) Perch-Nielsen (1968) 
Reinhardtites biperforatus (Gartner, 1968) Shafik (1979)

Rhagodiscus angustus (Stradner, 1963) Reinhardt (1971)

Rhagodiscus splendens (Deflandre, 1953) Verbeek (1977)

Rhombolithion rhombicum (Stradner and Adamiker, 1966) Black (1973)

Rotelapillus crenulatus (Stover, 1966) Perch-Nielsen (1984)

Stoverius asymmetricus (Bukry, 1969) Perch-Nielsen (1984)

Stoverius biarcus (Bukry, 1969) Perch-Nielsen (1984)

Stoverius coronatus (Bukry, 1969) Perch-Nielsen (1984)

Stradneria crenulata (Bramlette and Martini, 1964) Nöel (1970)

Tranolithus phacelosus Stover (1966)

Vekshinella elliptica Gartner (1968)

Vekshinella stradneri Rood, Hay, and Barnard (1971)

Watznaueria barnesae (Black, 1959) Perch-Nielsen (1968)

Zeugrhabdotus acanthus Reinhardt (1965)

Zeugrhabdotus pseudanthophorus (Bramlette and Martini, 1964) PerchNielsen (1984)

Cenozoic Species

Birkelundia staurion (Bramlette and Sullivan, 1961) Perch-Nielsen (1971) Blackites spinosus (Deflandre and Fert, 1954) Hay and Towe (1962)

Bomolithus elegans Roth (1973)

Braarudosphaera bigelowii (Gran and Braarud, 1935) Deflandre (1947)

Braarudosphaera discula Bramlette and Riedel (1954)

Bramletteius serraculoides Gartner (1969)

Calcidiscus protoannula (Gartner, 1971) Loeblich and Tappan (1978)

Camplyosphaera dela (Bramlette and Sullivan, 1961) Hay and Mohler (1967)

Camplyosphaera eodela (Burky and Percival, 1971)

Chiasmolithus californicus (Sullivan, 1964) Hay and Mohler (1967)

Chiasmolithus consuetus (Bramlette and Sullivan, 1961) Hay and Mohler (1967)

Chiasmolithus eograndis Perch-Nielsen (1971)

Chiasmolithus expansus (Bramlette and Sullivan, 1961) Gartner (1970)

Chiasmolithus gigas (Bramlette and Sullivan, 1961) Randomski (1968)

Chiasmolithus grandis (Bramlette and Riedel, 1954) Randomski (1968)

Chiasmolithus nitidus Perch-Nielsen (1971)

Chiasmolithus oamaruensis (Deflandre, 1954) Hay, Mohler, and Wade (1966)

Chiasmolithus solitus (Bramlette and Sullivan, 1961) Locker, 1968

Chiasmolithus titus Gartner (1970)

Chiphragmalithus acanthodes Bramlette and Sullivan (1961)

Chiphragmalithus armatus Perch-Nielsen (1971)

Chiphragmalithus barbatus Perch-Nielsen (1967)

Coccolithus eopelagicus (Bramlette and Riedel, 1954) Bramlette and Sullivan (1961)

Coccolithus pelagicus (Wallich, 1877) Schiller (1930)

Coronocyclus nitescens (Kamptner, 1963) Bramlette and Wilcoxon (1967)

Coronocyclus prionon (Deflandre and Fert, 1954) Stradner in Stradner and Edwards (1968)

Cribrocentrum reticulatum (Gartner and Smith, 1967) Perch-Nielsen (1971)

Cruciplacolithus cribellum (Bramlette and Sullivan, 1961) Romein (1979)

Cruciplacolithus mutatus Perch-Nielsen (1971)

Cruciplacolithus tarquinius Roth and Hay in Hay, Mohler, Roth, Schmidt, and Boudreaux (1967)

Cruciplacolithus tenuis (Stradner, 1961) Hay and Mohler in Hay, Mohler, Roth, Schmidt, and Boudreaux (1967)

Cruciplacolithus vanheckae Perch-Nielsen 1984

Cyclicargolithus floridanus (Roth and Hay in Hay, Mohler, Roth, Schmidt, and Boudreaux (1967) Bukry (1971)

Cyclicargolithus pseudogammation (Bouché, 1962) Bukry (1973)

Dictyococcites bisectus (Hay, Mohler, and Wade, 1966) Bukry and Percival (1971)

Dictyococcites daviesii (Haq, 1968) Perch-Nielsen (1971)

Dictyococcites scrippsae Bukry and Percival (1971)

Discoaster barbadiensis Tan (1927)

Discoaster bifax Bukry (1971)

Discoaster binodosus Martini (1958)

Discoaster cruciformis Martini (1968)

Discoaster deflandrei Bramlette and Riedel (1954)

Discoaster delicatus Bramlette and Sullivan (1961)

Discoaster diastypus Bramlette and Sullivan (1961)

Discoaster gemmifer Stradner (1961)

Discoaster germanicus Martini (1958)

Discoaster kuepperii Stradner (1959)

Discoaster lodoensis Bramlette and Reidel (1954)
Discoaster martinii Stradner (1959)

Discoaster multiradiatus Bramlette and Riedel (1954)

Discoaster nodifer (Bramlette and Riedel, 1954) Bukry (1973)

Discoaster nonoradiatus Klumpp (1953)

Discoaster saipanensis Bramlette and Riedel (1954)

Discoaster septemradiatus (Klumpp, 1953) Martini (1958)

Discoaster strictus Stradner (1961)

Discoaster sublodoensis Bramlette and Sullivan (1961)

Discoaster tanii Bramlette and Riedel (1954)

Discoaster trinus Stradner (1961)

Discoaster wemmelensis Actuthan and Stradner (1969)

Ellipsolithus distichus (Bramlette and Sullivan, 1961) Sullivan (1964)

Ellipsolithus lajollaensis Bukry and Percival (1971)

Ellipsolithus macellus (Bramlette and Sullivan, 1961) Sullivan (1964)

Ericsonia cava (Hay and Mohler, 1967) Perch-Nielsen (1969)

Ericsonia formosa (Kamptner, 1963) Haq (1971)

Ericsonia obruta Perch-Nielsen (1971)

Ericsonia ovalis Black (1968)

Ericsonia robusto

Ericsonia subpertusa Hay and Mohler (1967)

Fasciculithus bitectus Romein (1979)

Fasciculithus pileatus Bukry (1973)

Fasciculithus tympaniformis Hay and Mohler in Hay, Mohler, Roth, Schmidt. and Boudreaux (1967)

Fasciculithus ulii Perch-Nielsen (1971)

Hayella situliformis Gartner (1969)

Helicosphaera compacta Bramlette and Wilcoxon (1967)

Helicosphaera dinesenii Perch-Nielsen (1971)

Helicosphaera lophata Bramlette and Sullivan (1961)

Helicosphaera papillata Bukry and Bramlette (1969)

Helicosphaera seminulum Bramlette and Sullivan (1961)

Helicosphaera wilcoxonii Gartner (1971)

Heliolithus cantabriae Perch-Nielsen (1971)

Heliolithus kleinpellii Sullivan (1964)

Heliolithus floris Haq and Aubry (1981)

Lanternithus duocavus Locker (1967)

Lophodolithus acutus Bukry and Percival (1971)

Lophodolithus mochloporus Deflandre in Deflandre and Fert (1954)

Lophodolithus nascens Bramlette and Sullivan (1961)

Markaliius inversus (Deflandre in Deflandre and Fert, 1954) Bramlette and Martini (1964)

Nannotetrina cristata (Martini, 1958) Perch-Nielsen (1971)

Neochiastozygus chiastus (Bramlette and Sullivan, 1961) Perch-Nielsen (1971)

Neochiastozygus concinnus (Martini, 1961) Perch-Nielsen (1971)

Neochiastozygus distentus (Bramlette and Sullivan, 1961) Perch-Nielsen (1971)

Neochiastozygus junctus (Bramlette and Sullivan, 1961) Perch-Nielsen (1971) Neochiastozygus perfectus Perch-Nielsen (1971)

Neococcolithes dubius (Deflandre, 1954) Black (1967)

Neococcolithes protenus (Bramlette and Sullivan, 1961) Black (1967)

Neocrepidolithus bukryi Perch-Nielsen (1981)

Pemma basquensis (Martini, 1958) Bouché, 1962

Pemma stradnerii (Chang, 1969) Bybell and Gartner (1972)

Placozygus sigmoides (Bramlette and Sullivan, 1961) Romein (1979)

Pontosphaera distincta (Bramlette and Sullivan, 1961) Roth and Thierstein (1972)

Pontosphaera formosa (Bukry and Bramlette, 1969) Romein (1979)

Pontosphaera latoculata Bukry and Percival (1971) Perch-Nielsen (1984)

Pontosphaera multipora (Kamptner, 1948) Roth (1970)

Pontosphaera ocellata (Bramlette and Sullivan, 1961) Perch-Nielsen (1984)

Pontosphaera pectinata (Bramlette and Sullivan, 1961) Sherwood (1974)

Pontosphaera plana (Bramlette and Sullivan, 1961) Haq (1971)

Pontosphaera versa (Bramlette and Sullivan, 1961) Sherwood (1974)

Prinsius bisculus (Stradner, 1963) Hay and Mohler (1967)

Prinsius martinii (Perch-Nielsen, 1969) Haq (1971)

Pseudotriquetrorhabdus inversus (Bukry and Bramlette, 1969) Wise in Wise and Constans (1976)

Reticulofenestra dictyoda (Deflandre in Deflandre and Fert, 1954) Stradner in Stradner and Edwards (1968)

Reticulofenestra hillae Bukry and Percival (1971)

Reticulofenestra umbilica (Levin, 1965) Martini and Ritzkowski (1968)

Rhabdosphaera gladious Locker (1967)

Rhabdosphaera morionum (Deflandre in Deflandre and Fert, 1954) Bramlette and Sullivan (1961) 
Rhabdosphaera perlongus Deflandre in Grassé (1952)

Rhabdosphaera pseudomorionum Locker (1967)

Rhabdosphaera scabrosa Deflandre in Deflandre and Fert (1954)

Rhabdosphaera tenuis Bramlette and Sullivan (1961)

Scapholithus fossilis Deflandre in Deflandre and Fert (1954)

Scapholithus rhombiformis Hay and Mohler (1967)

Scyphosphaera biarritzensis Lezaud (1968)

Scyphosphaera columnella Stradner (1969)

Scyphosphaera expansa Bukry and Percival (1971)

Scyphosphaera tercisensis Lezaud (1968)

Scyphosphaera tubicena Stradner (1969)

Semihololithus kerabyi Perch-Nielsen (1971)

Sphenolithus anarrhopus Bukry and Bramlette (1969)

Sphenolithys conspicuus Martini (1976)

Sphenolithus editus Perch-Nielsen in Perch-Nielsen, Sadek, Barakaat, and Teleb (1978)

Sphenolithus furcatolithoides Locker (1967)

Sphenolithus intercalaris Martini (1976)

Sphenolithus moriformis (Brönnimann and Stradner, 1960) Bramlette and Wilcoxon (1967)

Sphenolithus orphanknollensis Perch-Nielsen (1971)

Sphenolithus predistentus Bramlette and Wilcoxon (1967)

Sphenolithus pseudoradians Bramlette and Wilcoxon (1967)

Sphenolithus primus Perch-Nielsen (1971)

Sphenolithus radians Deflandre in Grassé (1952)

Sphenolithus spiniger Bukry (1971)

Sphenolithus stellatus Gartner (1971)

Thoracosphaera heimii (Lohmann, 1919) Kamptner (1941)

Thoracosphaera saxea Stradner (1961)

Thoracosphaera tuberosa Stradner (1963)

Toweius callosus Perch-Nielsen (1971)

Toweius crassus (Bramlette and Sullivan, 1961) Perch-Nielsen (1984)

Toweius eminens (Bramlette and Sullivan, 1961) Perch-Nielsen (1971)

Toweius gammation (Bramlette and Sullivan, 1961) Romein (1979)

Toweius pertusus (Sullivan, 1965) Romein (1979)

Toweius selandianus Perch-Nielsen (1979)

Transversopontis latus Müller (1970)

Transversopontis pulcher (Deflandre in Deflandre and Fert, 1954) Perch-Nielsen (1967)

Transversopontis pulcheroides (Sullivan, 1964) Báldi-Beke (1971)

Tribrachiatus bramletti (Brönnimann and Stradner, 1960) Proto Decima, Roth, and Todesco (1975)

Tribrachiatus orthostylus Shamraî (1963)

Zyghrablithus bijugatus (Deflandre in Deflandre and Fert, 1954) Deflandre (1959)

Zygodiscus bramlettei Perch-Nielsen (1981)

\section{Planktonic Foraminifers Cited in This Report}

\section{Cretaceous Species}

Archaeoglobigerina cretacea (d'Orbigny, 1840) (= Globigerina cretacea d'Orbigny)

Contusotruncana fornicata (Plummer, 1921) (= Globotruncana fornicata Plummer)

Dicarinella asymmetrica $($ Sigal, 1952) $(=$ Globotruncana asymmetrica Sigal)

Dicarinella concavata (Brotzen, 1934) (= Rotalia concavata Brotzen)

Dicarinella primitiva (Dalbiez, 1955) (= Globotruncana ventricosa subsp. primitiva Dalbiez)

Globigerinelloides bollii Pessagno, 1967

Globigerinelloides caseyi (Bolli, Loeblich and Tappan, 1957) (= Planomalina caseyi Bolli, Loeblich and Tappan)

Globigerinelloides messinae (Bronnimann, 1952) (= Globigerinella messinae Bronnimann)

Globigerinelloides prairiehillensis Pessagno, 1967

Globigerinelloides subcarinatus (Bronnimann, 1952) $(=$ Globigerinella messinae subcarinata Bronnimann)

Globotruncana arca (Cushman, 1926) (= Pulvinulina arca Cushman)

Globotruncana bulloides Vogler, 1941

Globotruncana hilli Pessagno, 1967

Globotruncana lapparenti Brotzen, 1936

Globotruncana linneiana (d'Orbigny, 1839) (= Rosalina linneiana d'Orbigny)

Globotruncana rosetta (Carsey, 1926) (= Globigerina rosetta Carsey)
Globotruncana ventricosa White, 1928

Globotruncanita calcarata (Cushman, 1927) (= Globotruncana calcarata Cushman)

Globotruncanita elevata (Brotzen, 1934) (= Rotalia elevata Brotzen)

Globotruncanita stuartiformis (Dalbiez, 1955) (= Globotruncana stuartiformis Dalbiez)

Hedbergella planispira (Tappan, 1940) (= Globigerina planispira Tappan)

Heterohelix globulosa (Ehrenberg, 1840) (= Textularia globulosa Ehrenberg)

Heterohelix moremani (Cushman, 1938) (= Guembelina reussi Cushman)

Heterohelix punctulata (Cushman, 1938) (= Guembelina punctulata Cushman)

Heterohelix reussi (Cushman, 1938) (= Guembelina reussi Cushman)

Marginotruncana coronata (Bolli, 1945) (= Globotruncana lapparenti subsp. coronata Bolli)

Marginotruncana marginata (Reuss, 1845) (= Rosalina marginata Reuss)

Marginotruncana pseudolinneiana Pessagno, 1967

Marginotruncana renzi (Gandolfi, 1942) (= Globotruncana renzi Gandolfi)

Marginotruncana schneegansi (Sigal, 1952) (= Globotruncana schneegansi Sigal)

Marginotruncana sigali (Reichel, 1950) (= Globotruncana sigali Reichel)

Planomalina praebuxtorfi Wonders, 1975

Pseudoguembelina costulata (Cushman, 1938) (= Guembelina costulata Cushman)

Pseudotextularia sp.

Ventilabrella eggeri Cushman, 1928

Ventilabrella glabrata Cushman, 1928

\section{Paleocene and Eocene Species}

Acarinina bullbrooki (Bolli, 1957) (= Globorotalia bullbrooki Bolli)

Acarinina esnaensis (Le Roy, 1953) (= Globigerina esnaensis Le Roy)

Acarinina intermedia Subbotina, 1953

Acarinina nitida (Martin, 1943) (= Globigerina nitida Martin)

Acarinina pentacamerata Subbotina, 1953

Acarinina pseudotopilensis Subbotina, 1953

Acarinina rohri (Bronnimann and Bermudez, 1953) (= Truncorotaloides rohri Bronnimann and Bermudez)

Acarinina spinuloinflata (Bandy, 1949) (= Globigerina spinuloinflata Bandy)

Clavigerinella sp.

Globanomalina chapmani (Parr, 1938) (= Globorotalia chapmani Parr)

Globanomalina compressa (Plummer, 1926) (= Globigerina compressa Plummer)

Globanomalina ehrenbergi $($ Bolli, 1957) $(=$ Globorotalia ehrenbergi Bolli)

Globanomalina palmerae (Cushman and Bermudez, 1937) (= Globorotalia palmerae Cushman and Bermudez)

Globanomalina planoconica (Subbotina,1953) (= Globorotalia planoconica Subbotina)

Globanomalina pseudomenardii (Bolli, 1957) (= Globorotalia pseudomenardii Bolli)

Globanomalina pseudoscitula (Glaessner, 1937) (= Globorotalia pseudoscitula Glaessner)

"Globigerinatheka" senni (Beckmann, 1953) (= Sphaeroidinella senni Beckmann)

Globigerinatheka euganea Proto Decima and Bolli, 1970

Globigerinatheka index Finlay, 1939) (= Globigerinoides index Finlay)

Globigerinatheka mexicana (Cushman, 1925) (= Globigerina mexicana Cushman)

Globigerinatheka micra (Shutskaya, 1958) (= Globigerinoides subconglobatus var. micra Shutskaya)

Globigerinatheka rubriformis (Subbotina, 1953) (= Globigerinoides ribrifor mis Subbotina)

Globigerinatheka subconglobata (Shutskaya, 1958) (= Globigerinoides subconglobatus Shutskaya)

Globigerinatheka micra (Shutskaya, 1958) (= Globigerinoides subconglobatus var. micra Shutskaya)

Globigerinatheka tropicalis (Blow and Banner, 1962) (Globigerapsis tropicalis Blow and Banner)

Guembelitrioides higginsi (Bolli, 1957) (= "Globigerinoides" higginsi Bolli)

"Guembelitrioides" lozanoi (Colom) (= Globigerina lozanoi Colom)

Hantkenina sp.

Igorina broedermanni (Cushman and Bermudez, 1949) (= Globorotalia broedermanni Cushman and Bermudez)

Morozovella abundocamerata $($ Bolli, 1957) $)(=$ Globorotalia abundocamerata Bolli) 
Morozovella acuta (Toulmin, 1941) (= Globorotalia wilcoxensis var. acuta Toulmin)

Morozovella aequa (Cushman and Renz, 1942) (= Globorotalia crassata (Cushman) var. aequa Cushman and Renz)

Morozovella angulata (White, 1928) (= Globigerina angulata White)

Morozovella aragonensis (Nuttall,1930) (= Globorotalia aragonenis Nuttall)

Morozovella caucasica (Glaessner, 1937) (= Globorotalia caucasica Glaessner)

Morozovella conicotruncata (Subbotina, 1947) (= Globorotalia conicotruncata Subbotina)

Morozovella crassata (Cushman, 1925) (= Pulvinulina crassata Cushman)

Morozovella gracilis (Bolli, 1957) (= Globorotalia formosa gracilis Bolli)

Morozovella formosa (Bolli, 1957) (= Globorotalia formosa Bolli)

Morozovella indolensis (Morozova, 1959) (= Globorotalia indolensis Morozova)

Morozovella laevigata (Bolli, 1957) (= Globorotalia pusilla laevigata Bolli)

Morozovella lehneri (Cushman and Jarvis, 1929) (= Globorotalia lehneri Cushman and Jarvis)

Morozovella occlusa (Loeblich and Tappan, 1957) (= Globorotalia occlusa Loeblich and Tappan)

Morozovella pusilla (Bolli, 1957) (= Globorotalia pusilla pusilla Bolli)

Morozovella simulatilis (Schwager, 1883) (= Discorbina simulatilis Schwager)

Morozovella spinulosa (Cushman, 1927) (= Globorotalia spinulosa Cushman)

Morozovella velascoensis (Cushman, 1925) (= Pulvinulina velascoensis Cushman)

Muricoglobigerina mckannai (White, 1928) (= Globigerina mckannai White)

Muricoglobigerina soldadoensis (Bronnimann, 1952) (= Globigerina soldadoensis Bronnimann)

Orbulinoides beckmanni (Saito, 1962) (= Porticulasphaera beckmanni Saito)

Parasubbotina pseudobulloides (Plummer, 1926) (= Globigerina pseudobulloides Plummer)

Pseudohastigerina danvillensis (Howe and Wallace, 1932) $(=$ Nonion danvillensis Howe and Wallace)

Pseudohastigerina micra (Cole, 1927) (= Nonion micrus Cole)
Pseudohastigerina wilcoxensis (Cushman and Ponton, 1932) (= Nonion wilcoxensis Cushman and Ponton)

Pseudohastigerina naguewichiensis (Myatliuk, 1950) (= Globigerinella naguewichiensis Myatliuk)

Subbotina eocaenica (Terquem, 1882) (= Globigerina eocaenica Terquem)

"Subbotina" gortanii (Borsetti, 1959) (= Globigerina gortanii Borsetti)

Subbotina triloculinoides (Plummer, 1926) (= Globigerina triloculinoides Plummer)

Truncorotaloides topilensis (Cushman, 1925) (= Globigerina topilensis Cushman)

Turborotalia cerroazulensis (Cole, 1928) (= Globigerina cerroazulensis Cole)

Turborotalia cocoaensis (Cushman, 1928) (= Globorotalia cocoaensis Cushman)

Turborotalia boweri (Bolli, 1957) (= Globorotalia boweri Bolli)

Turborotalia pomeroli (Toumarkine and Bolli, 1970) (= Globorotalia cerroazulensis pomeroli Toumarkine and Bolli)

Turborotalia possagnoensis (Toumarkine and Bolli, 1970) (= Globorotalia cerroazulensis possagnoensis Toumarkine and Bolli)

Turborotalia frontosa (Subbotina, 1953) (= Globigerina frontosa Subbotina)

\section{Oligocene and Miocene Species}

Catapsydrax sp.

Globoquadrina binaiensis (Koch, 1935) (= Globigerina binaiensis Koch)

Globoquadrina rohri (Bolli, 1957) (= Globigerina rohri Bolli)

Globoquadrina sellii Borsetti, 1959

Globoquadrina tripartita (Koch, 1926) (= Globigerina bulloides tripartita Koch)

Globorotaloides sp.

Turborotalia increbescens (Bandy, 1949) (= Globigerina increbescens Bandy)

Turborotalia pseudoampliapertura (Blow and Banner, 1962) (= Globigerina pseudoampliapertura Blow and Banner)

Zeaglobigerina ampliapertura (Bolli, 1957) (= Globigerina ampliapertura Bolli) 

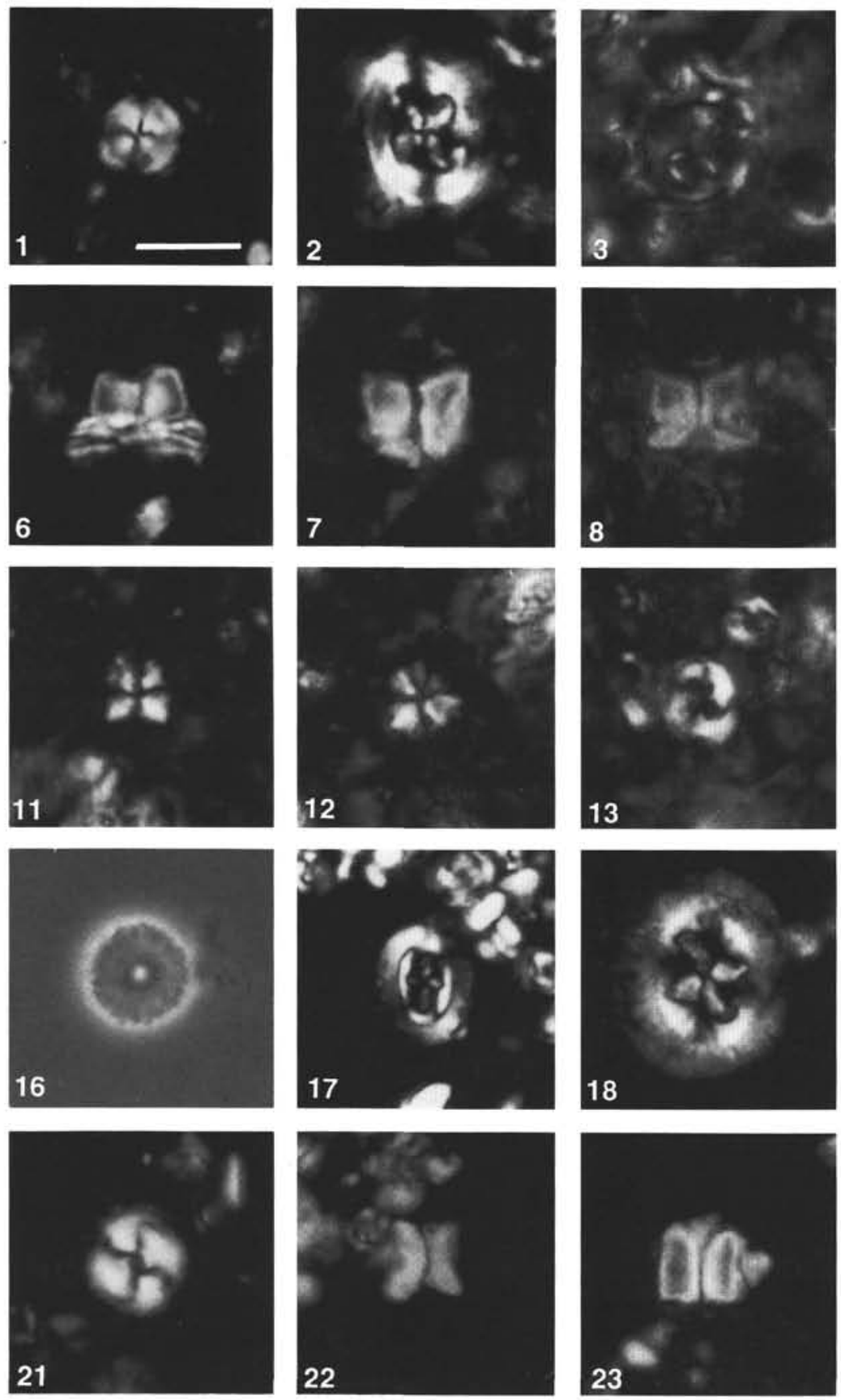
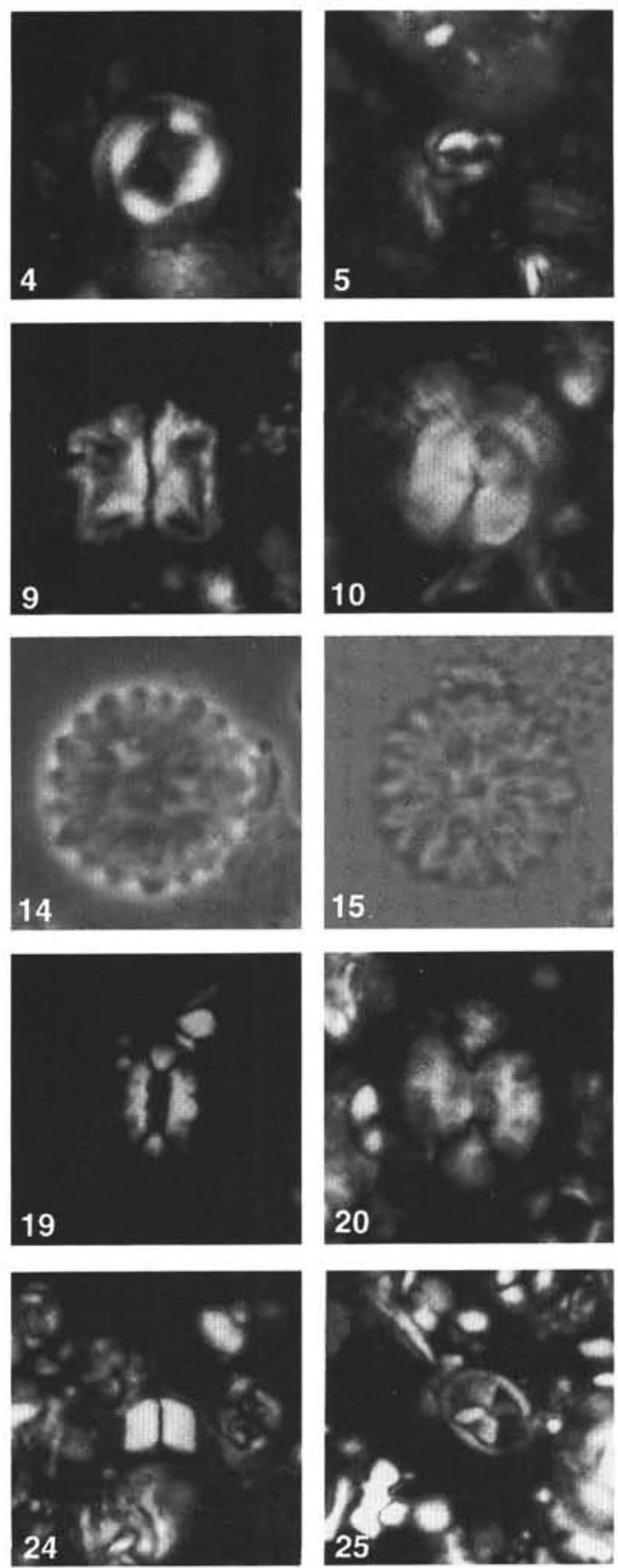

Plate 1. Magnification approximately 1400x. Scale bar in Figure $1=10 \mu \mathrm{m}$. Figures 1-12 from Sample 144-873A-2R-1, 0-2 cm; Figures 13-25 from Sample 144-877A-2R-1,0-1 cm. 1. Bomolithus elegans. 2. Chiasmolithus consuetus. 3. Ericsonia cava coccosphere. 4. Ericsonia robusta. 5. Prinsius bisulcus. 6. Fasciculithus bitectus. 7. Fasciculithus tympaniformis. 8. Fasciculithus bobii. 9. Fasciculithus ulii. 10. Heliolithus cantabriae. 11, 12. Sphenolithus primus. 13. Toweius pertusus. 14, 15. Discoaster multiradiatus. 16. Discoaster delicatus. 17. Camplyosphaera eodela. 18. Ellipsolithus distichus. 19. Chiasmolithus californicus. 20. Ellipsolithus macellus. 21. Ericsonia subpertusus. 22. Fasciculithus billii. 23. Fasciculithus typaniformis. 24. Fasciculithus clinatus. 25. Neochiastozygus perfectus. 

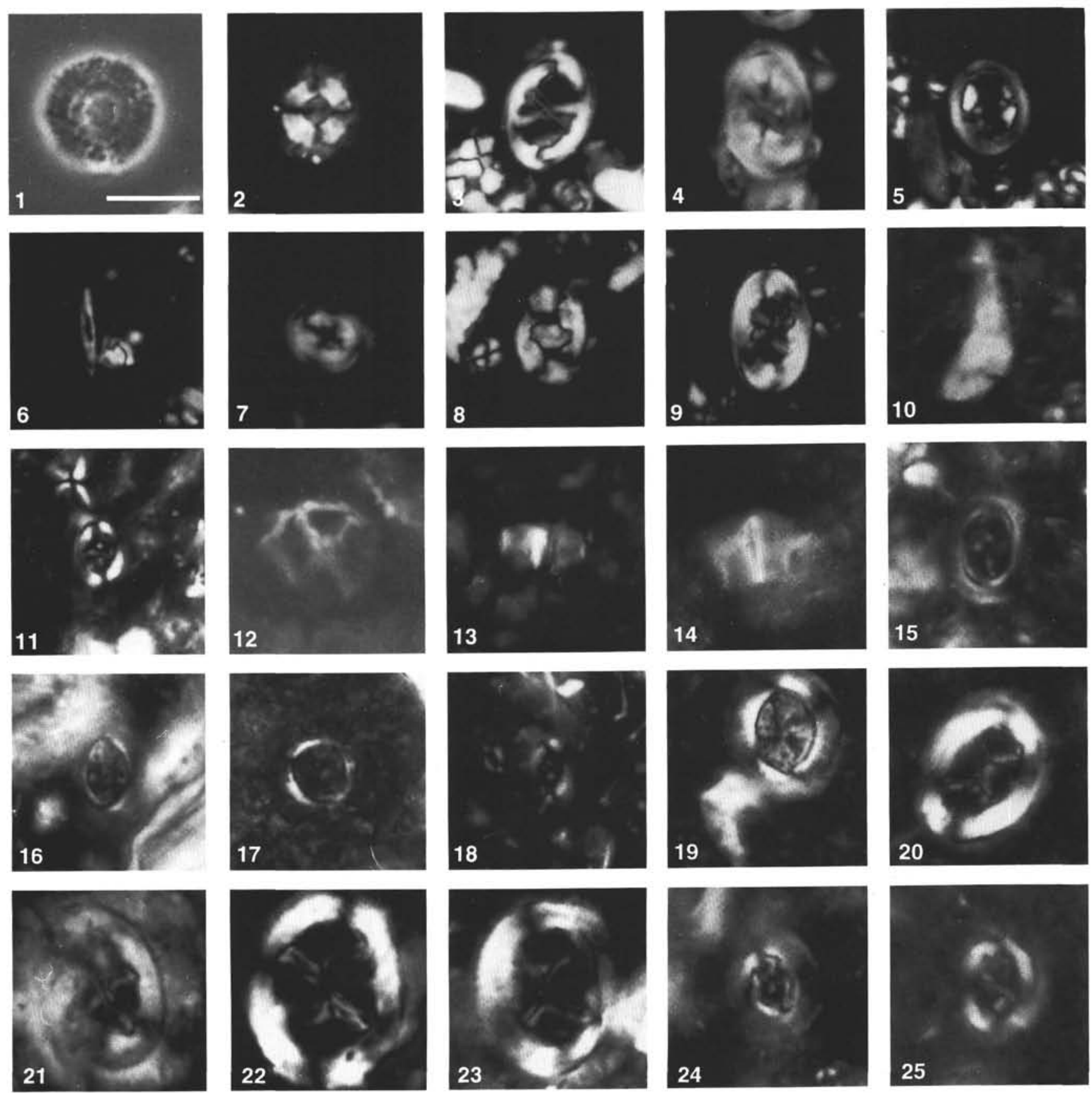

Plate 2. Magnification approximately 1400x. Scale bar in Figure $1=10 \mu \mathrm{m}$. Figures 1-9 from Sample 144-877A-2R-1, 0-1 cm. 1, 2. Heliolithus floris. 3. Neochiastozygus junctus. 4. Neocrepidolithus bukryi. 5. Placozygus sigmoides. 6. Scapholithus fossilis. 7. Toweius eminens. 8. Zygodiscus bramlettei. 9. Neochiastozygus distentus. 10. Bramlettius serraculoides, Sample 144-876A-1R-1, 34-35 cm. 11. Birkelundia staurion, Sample 144874A-1R-1, 7-13 cm. 12. Chiphragmalithus acanthoides, Sample 144-873A-1R-1,21-25 cm. 13. Chiphragmalithus armatus, Sample 144-874A-1R-1, $3-6 \mathrm{~cm}$. 14. Chiphragmalithus barbata, Sample 144-873A-1R-1, 21-25 cm. 15. Camplyosphaera dela, Sample 144-873A-2R-1, 0-2 cm. 16. Cruciplacolithus cribellum, Sample 144-874B-1R-1, 47-50 cm. 17. Cruciplacolithus mutatus, Sample 144-876A-1R-1, 12-17 cm. 18. Cruciplacolithus tarquinius, Sample 144-873B-8N-1,11-14 cm. 19. Cruciplacolithus vanheckae, Sample 144-873B-8N-1,11-14 cm. 20. Chiasmolithus solitus, Sample 144-873A-2R-1,0-2 cm. 21. Chiasmolithus gigas, Sample 144-873B-8N-1,11-14 cm. 22. Chiasmolithus solitus, Sample 144-873A-2R-1, 0-2 cm. 23. Chiasmolithus expansus, Sample 144-873B-10N-1, 1-10 cm. 24. Chiasmolithus nitidus, Sample 144-876A-1R-1, 12-17 cm. 25. Chiasmolithus titus, Sample 144-873A-1R-1, 21-25 cm. 

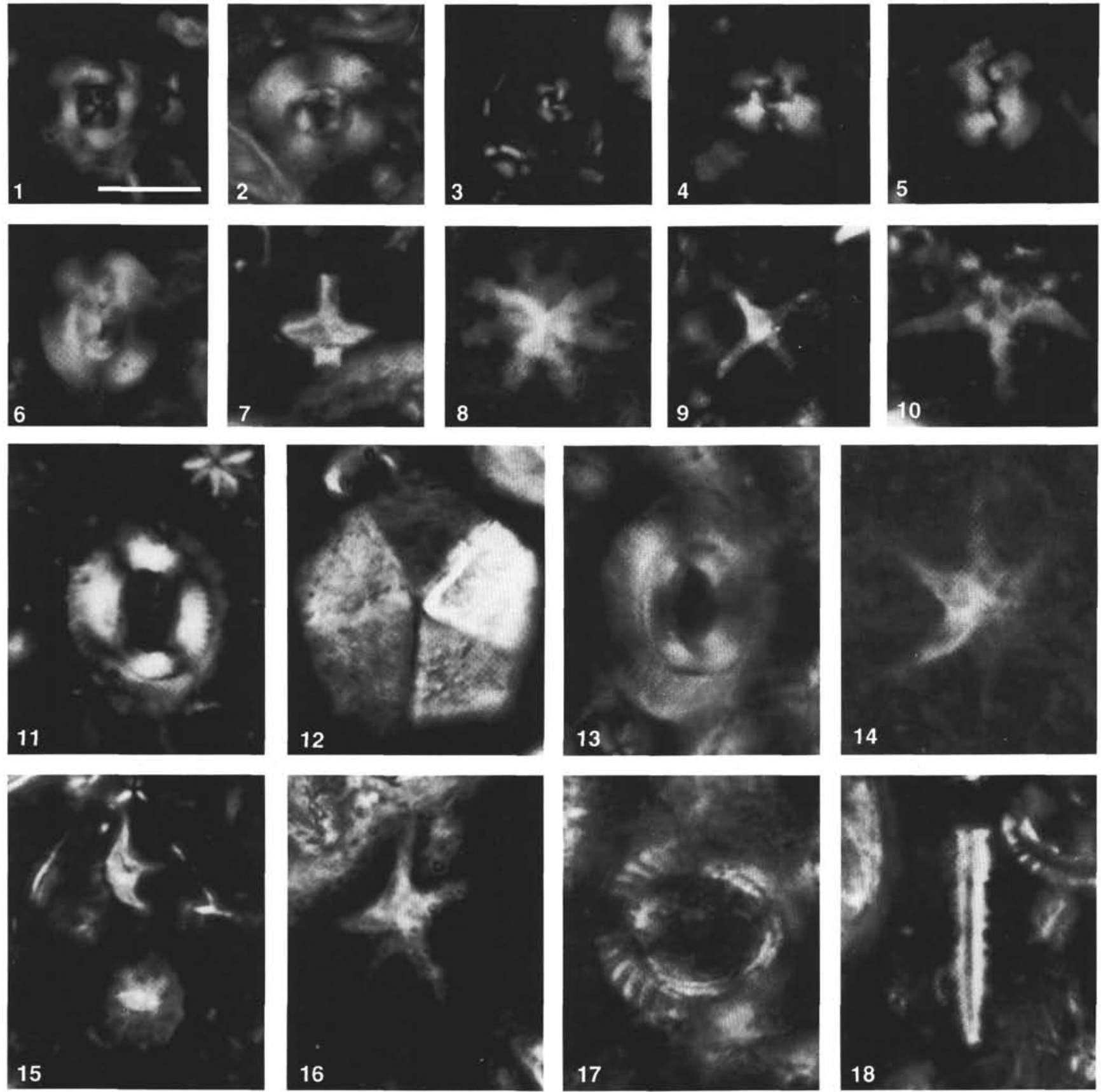

Plate 3. Magnification approximately $1400 \times$. Scale bar in Figure $1=10 \mu \mathrm{m}$. 1. Cribrocentrum reticulatum, Sample 144-876A-1R-1, 34-35 cm. 2. Cyclicargolithus floridanus, Sample 144-873A-1R-1,21-25 cm. 3. Cyclicargolithus marismontium(?), Sample 144-876A-1R-1, 34-35 cm. 4. Cyclicargolithus pseudogammation, Sample 144-876A-1R-1, 34-35 cm. 5. Dictyococcites scrippsae, Sample 144-876A-1R-1, 34-35 cm. 6. Dictyococcites bisecta, Sample 144-876A-1R-1, 34-35 cm. 7. Discoaster bifax, Sample 144-873A-1R-1, 21-25 cm. 8. Discoaster binodosus, Sample 144-873A-1R-1, 21-25 cm. 9, 10. Discoaster cruciformis, Sample 144-873A-1R-1, 21-25 cm. 11. Coccolithus pelagicus, Sample 144-876A-1R-1, 34-35 cm. 12. Braarudosphaera bigelowii, Sample 144-874A-1R-1, 7-13 cm. 13. Coccolithus eopelagicus, Sample 144-873A-1R-1, 21-25 cm. 14. Discoaster lodoensis, Sample 144-876A-1R-1, 12-17 cm. 15. Discoaster barbadiensis (top = side view, bottom = oblique proximal view), Sample 144-874A-1R-1, 7-13 cm. 16. Discoaster sublodoensis, Sample 144-876A-1R-1, 12-17 cm. 17. Pontosphaera formosa, Sample 144-873B-8N-1, 11-14 cm. 18. Rhabdosphaera scabrosa, Sample 144-874A-1R-1, 7-13 cm. 

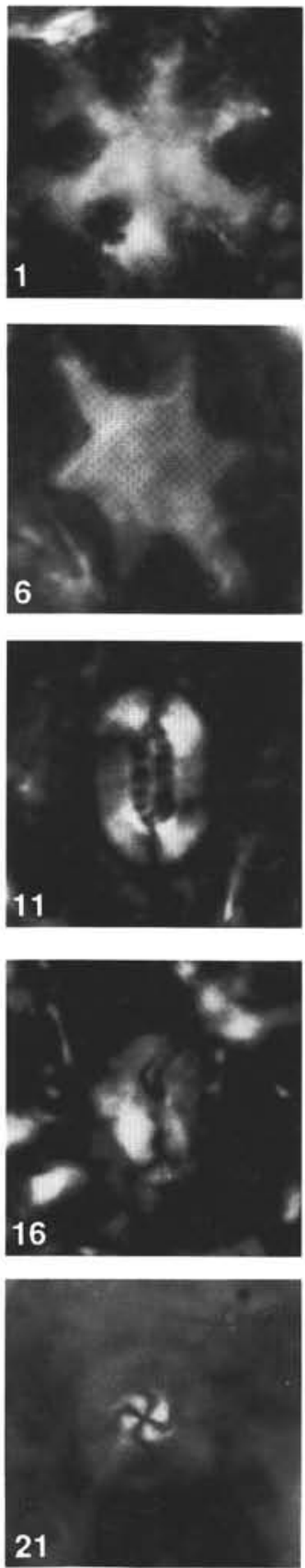
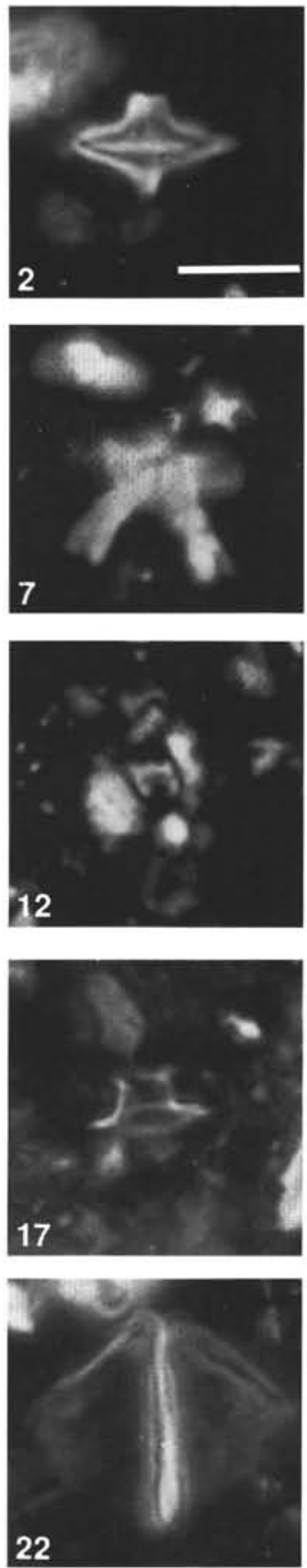
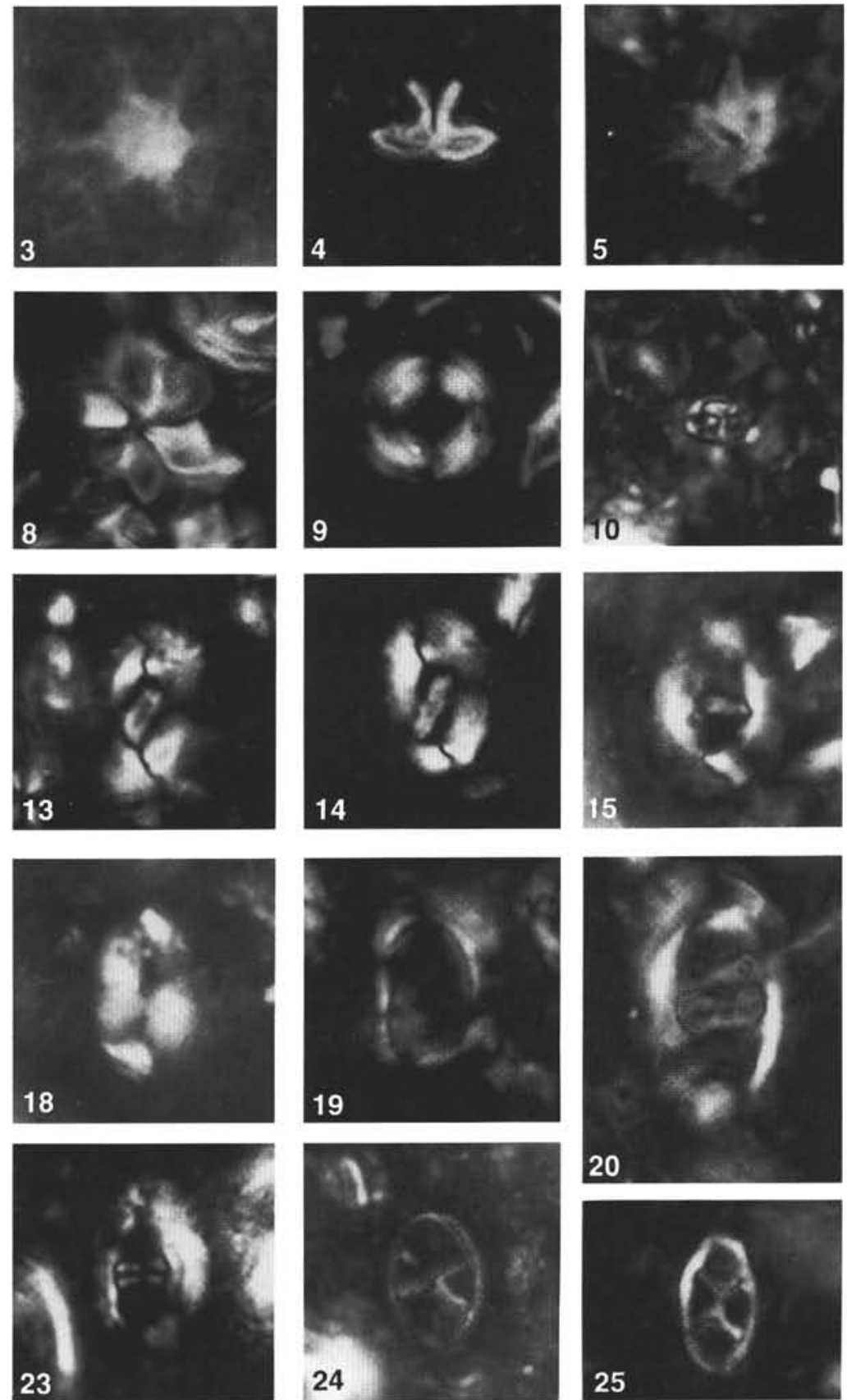
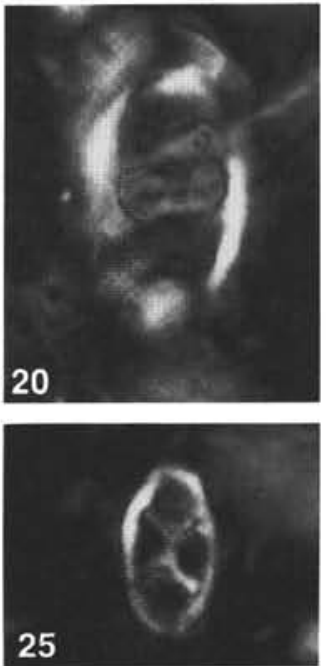

Plate 4. Magnification approximately 1400x. Scale bar in Figure $2=10 \mu \mathrm{m}$. 1. Discoaster deflandrei encased in hydrous manganese oxide, transmitted light, Sample 144-875C-1M-1, 7-12 cm. 2. Discoaster diastypus, Sample 144-873A-2R-1, 0-2 cm. 3. Discoaster germanicus, Sample 144-876A-1R-1, 34-35 cm. 4. Discoaster kuepperii, Sample 144-876A-1R-1, 12-17 cm. 5. Discoaster saipanensis, Sample 144-873B-8N-1, 11-14 cm. 6. Discoaster strictus, Sample 144-873B-8N-1, 11-14 cm. 7. Discoaster tanii, Sample 144-876A-1R-1,34-35 cm. 8. Discoaster trinus, Sample 144-874A-1R-1, 7-13 $\mathrm{cm}$. 9. Ericsonia formosa, Sample 144-873A-2R-1,0-2 cm. 10. Ericsonia obruta, Sample 144-876A-1R-1, 34-35 cm. 11. Ellipsolithus lajollaensis, Sample 144-876A-1R-1, 12-17 cm. 12. Helicosphaera wilcoxonii, Sample 144-876A-1R-1,34-35 cm. 13. Helicosphaera dinesenii, Sample 144-874BIR-1, 47-50 cm. 14. Helicosphaera lophata, Sample 144-876A-1R-1, 12-17 cm. 15. Helicosphaera seminulum, Sample 144-876A-1R-1, 12-17 cm. 16. Helicosphaera compacta, Sample 144-876A-1R-1,34-35 cm. 17. Hayella situliformis, Sample 144-874B-1R-1, $47-50 \mathrm{~cm} .18$. Lanternithus duocavus, Sample 144-873A-1R-1, 21-25 cm. 19. Lophodolithus acutus, Sample 144-873B-8N-1, 11-14 cm. 20. Lophodolithus mochloporus, Sample 144-876A-1R-1, 12-17 cm. 21. Markalius inversus, Sample 144-874A-1R-1, 3-6 cm. 22. Nannotetrina cristata, Sample 144-873B-10N-1, 1-10 cm. 23. Lophodolithus nascens, Sample 144-873B-8N-1, 0-3 cm. 24. Neococcolithus protenus, Sample 144-876A-1R-1, 12-17 cm. 25. Neococcolithus dubius, Sample 144-874A-1R-1, 7-13 cm. 

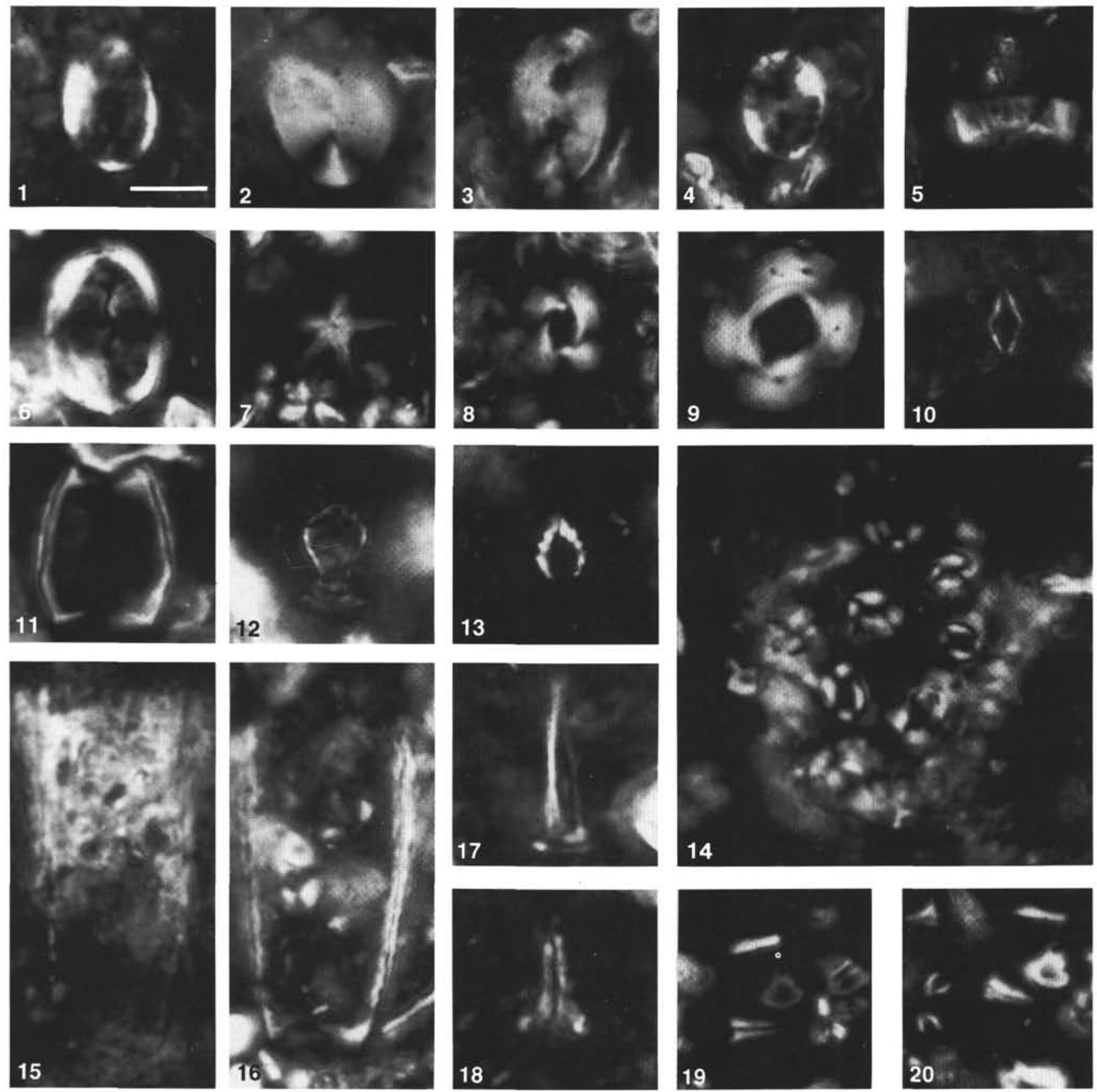

Plate 5. Magnification approximately $1400 \times$. Scale bar in Figure $1=10 \mu \mathrm{m}$. 1. Pontosphaera latoculata, Sample 144-874A-1R-1,3-6 cm. 2. Pontosphaera plana, Sample 144-874A-1R-1, 3-6 cm. 3. Pontosphaera ocellata, Sample 144-874B-1R-1, 47-50 cm. 4. Pontosphaera pectinata, Sample 144-874A-1R-1, 7-13 cm. 5. P. pectinata, side view, Sample 144-874B-1R-1, 7-10 cm. 6. Pontosphaera versa, Sample 144-876A-1R-1, $12-17 \mathrm{~cm} . \quad 7$. Micrantholithus inaequalis, Sample 144-873A-1R-1, 21-25 cm. 8. Reticulofenestra dictyoda, Sample 144-874B-1R-1, 47-50 cm. 9. Reticulofenestra umbilica, Sample 144-873A-1R-1, 21-25 cm. 10. Scapholithus rhombiformis, Sample 144-874A-1R-1, 7-13 cm. 11. Scyphosphaera biarritzensis, Sample 144-874A-1R-1, 3-6 cm. 12. Rhabdosphaera morionum, Sample 144-876A-1R-1, 12-17 cm. 13. Rhabdosphaera pseudomorionum, Sample 144-874A-1R-1, 7-13 cm. 14. Coccolithus pelagicus coccosphere, Sample 144-873A-2R-1, 0-2 cm. 15. Scyphosphaera expansa, Sample 144-873B$8 \mathrm{~N}-1,11-14 \mathrm{~cm}$. 16. Scyphosphaera columnella, Sample 144-873A-1R-1, 21-25 cm. 17. Rhabdosphaera creber, 144-873A-1R-1, 21-25 cm. 18. Semihololithus kerabyi, Sample $144-873 \mathrm{~B}-8 \mathrm{~N}-1,11-14 \mathrm{~cm} . \quad \mathbf{1 9}, 20$. Sphenolithus intercalaris, $0^{\circ}$ and $45^{\circ}$ to polarizer, Sample $144-873 \mathrm{~A}-1 \mathrm{R}-1,0-5 \mathrm{~cm}$. 

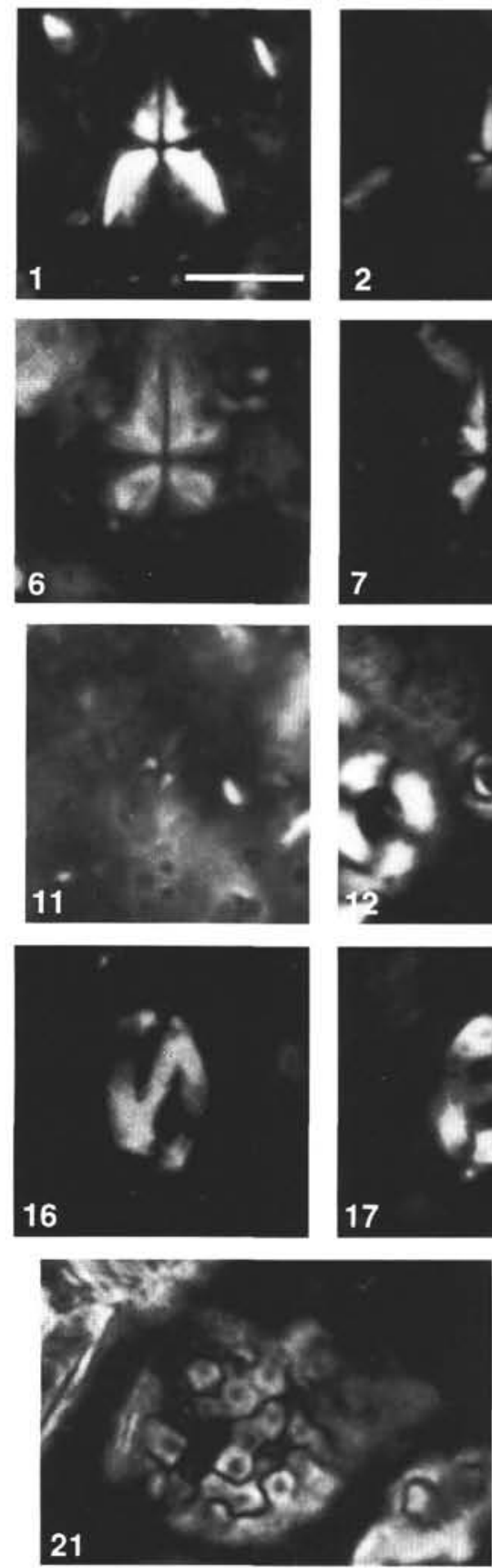
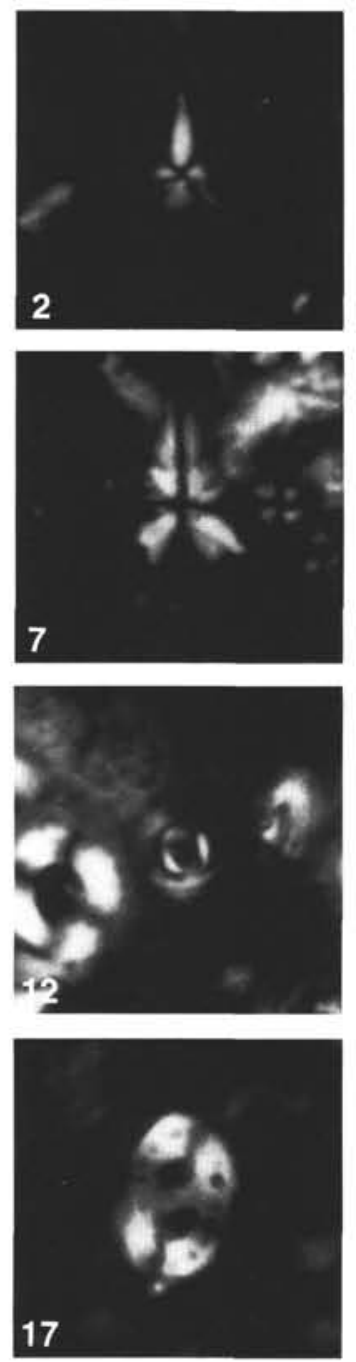

13
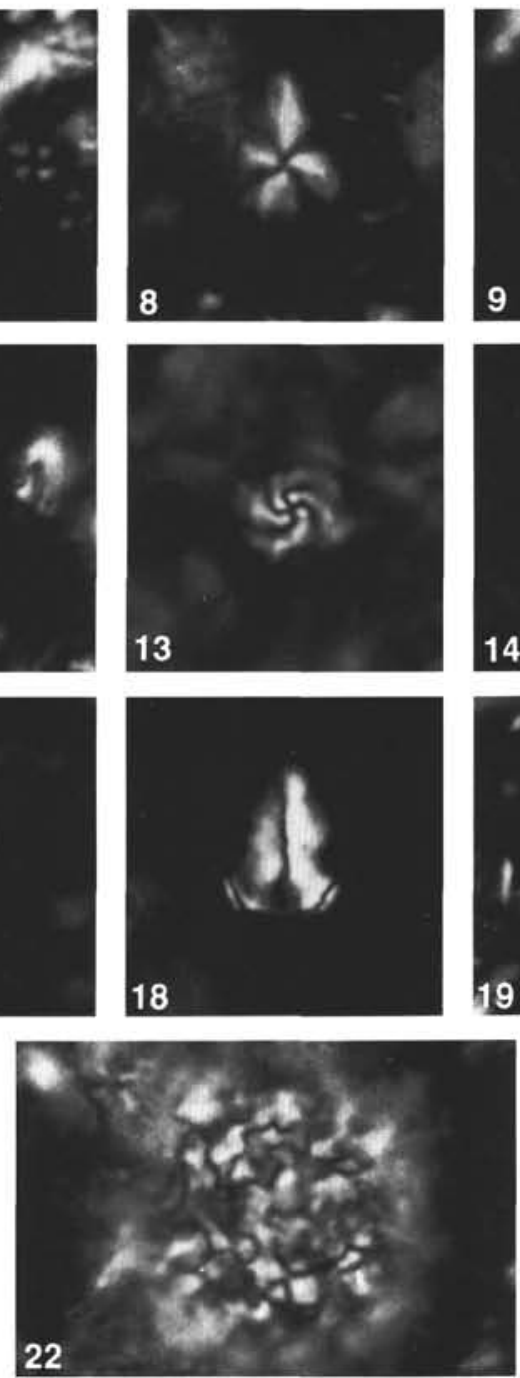

9
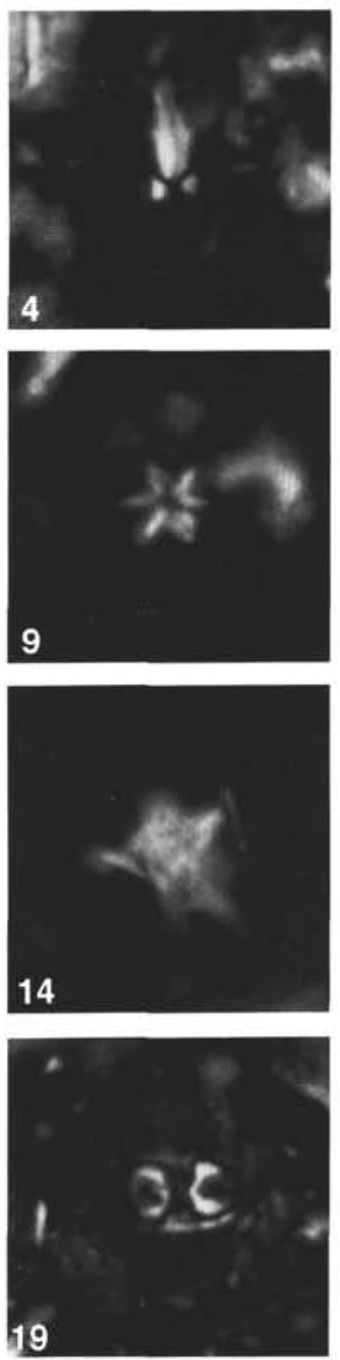

15
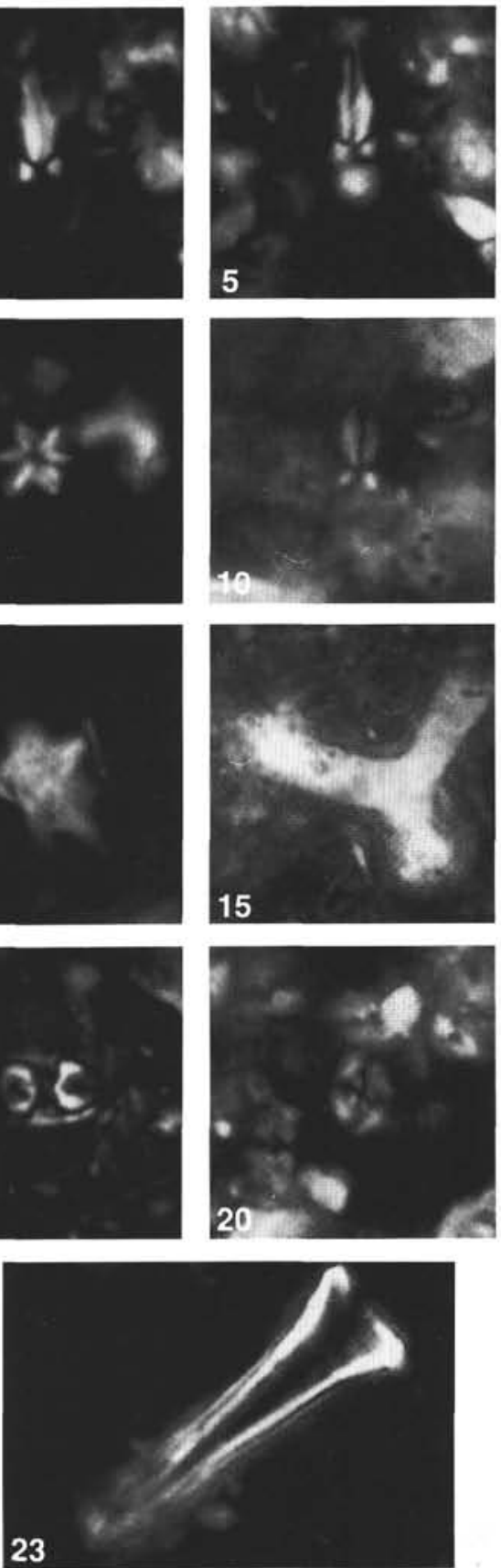

Plate 6. Magnification approximately 1400x. Scale bar in Figure $1=10 \mu \mathrm{m}$. 1. Sphenolithus editus, Sample 144-873B-8N-1, 0-3 cm. 2,3. Sphenolithus orphanknollensis, $45^{\circ}$ and $0^{\circ}$ to polarizer, Sample 144-873A-1R-1, 21-25 cm. 4, 5. Sphenolithus predistentus, $45^{\circ}$ and $0^{\circ}$ to polarizer, Sample 144-873A-IR-1, 21-25 cm. 6. Sphenolithus pseudoradians, Sample 144-873A-1R-1, 21-25 cm. 7, 8. Sphenolithus spiniger, $0^{\circ}$ and $45^{\circ}$ to polarizer, Sample 144-874B-1R-1, 47-50 cm. 9. Sphenolithus stellatus, Sample 144-873A-2R-1, 0-2 cm. 10, 11. Sphenolithus furcatolithoides, $0^{\circ}$ and $45^{\circ}$ to polarizer, Sample 144-874A-1R-1, 7-13 cm. 12. Toweius crassus, Sample 144-876A-1R-1, 12-17 cm. 13. Toweius gammation, Sample 144-874A-1R-1, 3-6 cm. 14. Tribrachiatus bramlettei (reworked?), Sample 144-873B-8N-1, 0-3 cm. 15. Tribrachiatus orthostylus, Sample 144-876A-1R-1, 12-17 cm. 16. Transversopontis latus, Sample 144-873A-1R-1, 21-25 cm. 17. Transversopontis pulcher, Sample 144-873A-2R-1, 0-2 cm. 18, 19. Zyghrablithus bijugatus, side and top view, Sample 144-874A-1R-1, 7-13 cm. 20. Watznaueria barnesae, Sample 144-876A-1R-1, 12-17 cm. 21. Thoracosphaera heimii, Sample 144-876A-1R-1, 12-17 cm. 22. Thoracosphaera saxea, Sample 144-876A-1R-1, 12-17 cm. 23. Scyphosphaera tubicena, Sample $144-874 \mathrm{~A}-1 \mathrm{R}-1,7-13 \mathrm{~cm}$. 